\title{
STRATEGI PEMASARAN PARIWISATA DI KABUPATEN BULELENG, BALI
}

\author{
Ni Made Ary Widiastini ${ }^{1}$, Nyoman Dini Andiani ${ }^{2}$, Trianasari $^{3}$ \\ 1, 2, 3 Jurusan Perhotelan DIII, Fakultas IImu Sosial, Universitas Pendidikan Ganesha, \\ Singaraja, Indonesia \\ e-mail: ary.widiastini@gmail.com,dini_mph@undiksha.ac.id, trianasari@yahoo.com
}

\begin{abstract}
Abstrak
Penelitian ini dianalisis dengan metode Strength Weakness Opportunity Threat (SWOT) dengan memperhatikan matriks Eksternal Factor Analysis Summary (EFAS) dan Internal Factor Analysis Summary (IFAS). Berdasarkan hasil temuan di lapangan dengan menggunakan analisis SWOT, strategi pemasaran yang dapat diterapkan oleh kepariwisataan Buleleng diantaranya: (1) Strategi strength dan opportunity (SO) diantaranya: mengkemas paket wisata dalam berbagai harga dan varian, menciptakan program yang berbasis budaya lokal dan ramah lingkungan, memanfaatkan teknologi dalam operasional sehingga mudah dalam memberikan pelayanan, mengembangkan programprogram yang menarik dengan memberdayakan masyarakat lokal, menciptakan produk yang sesuai antara harga dan nilai yang terdapat di dalamnya (value for money), dan pemberian Guide Fee; (2) Strategis strength dan threat (ST) diantaranya: melakukan diversifikasi produk wisata dan meningkatkan peran serta pemerintah daerah; (3) Strategi weakness dan opportunity (WO) diantaranya: meningkatkan media promosi dan kemudahan pelayanan melalui penggunaan teknologi informasi, meningkatkan kualitas sumber daya manusia dan menjaga kebersihan lingkungan sekitar dengan mengembangkan produk yang ramah lingkungan dan pemberian Guide Fee; (4) Strategi weakness dan threat (WT) diantaranya: melakukan kajian terhadap pengembangan pariwisata Kabupaten Buleleng, meningkatkan informasi tentang pariwisata Buleleng dan melakukan kreatifitas terhadap produk hotel. Faktor terpenting dalam pemasaran pariwisata adalag peningkatan peran serta pemerintah daerah, melakukan diversifikasi produk dan meningkatkan kualitas layanan pariwisata.
\end{abstract}

Kata Kunci: Strategi Pemasaran, Pariwisata, Kabupaten Buleleng 


\begin{abstract}
This research are analyzed with strength, weakness, opportunity, and threat (SWOT) analysis by using the external factor analysis summary (EFAS) and internal factor analysis summary (IFAS). Based on matrix of SWOT, the are some marketing alternative strategies of tourims that can be applied in Buleleng regency there are: (1) SO Strategy: create the tour package, create the local program and increase the local involvement, create a tourist product by understanding of the value for money and prepare a guide fee; (2) Strategy ST: the local government involvement should be improving; (3) Strategy of WO: improve the promotion of Buleleng tourism in many media, improve the quality of human resource and keep the environment clean, guide fee; (4) Strategy of WT: do the study of tourism in deep in order to develop the tourism of Buleleng regency and create the hotel product. Based on the analysis, the important factor that involvement the tourism marketing in Buleleng regency are: the role and local government, diversify the tourist product and increase the tourist services.
\end{abstract}

Keyword: Marketing Strategy, Tourism, Buleleng Regency

\section{PENDAHULUAN}

Kabupaten Buleleng sebagai daerah tujuan wisata memiliki beberapa kelemahan, sehingga wisatawan yang berkunjung relatif kecil bila dibandingkan dengan daerah lain yang berada di bagian selatan pulau Bali. Kelemahan-kelemahan tersebut diantaranya jarak ke ibu kota propinsi dan bandara udara yang cukup jauh, jalan yang berliku dan kurang tepatnya strategi promosi wisata. Terlebih lagi melihat sejarah Bali yang dahulu Ibu Kota Propinsi terletak di Kabupaten Buleleng termasuk menjadi pintu masuk bagi orang asing melalui pelabuhan laut, sesungguhnya Kabupaten Buleleng telah dikenal oleh wisatawan dari tahun 1920an (Diparda, 2003). Padahal sesungguhnya Kabupaten Buleleng memiliki banyak daya tarik wisata alam dan budaya yang dapat dikemas ke dalam berbagai jenis paket wisata seperti wisata spiritual dan ekowisata yang sedang disegani oleh wisatawan, terutama wisatawan manca negara.

Melihat potensi-potensi tersebut, perlu adanya strategi pemasaran yang tepat sehingga sasaran dan tujuan dapat dicapai.
Namun, sebagai daerah tujuan wisata Kabupaten Buleleng memiliki beberapa kelemahan, sehingga wisatawan yang berkunjung relatif kecil bila dibandingkan dengan daerah lain yang berada di bagian selatan pulau Bali. Kelemahan-kelemahan tersebut diantaranya jarak ke ibu kota propinsi dan bandara udara yang cukup jauh, jalan yang berliku dan kurang tepatnya strategi promosi wisata. Terlebih lagi melihat sejarah Bali yang dahulu Ibu Kota Propinsi terletak di Kabupaten Buleleng termasuk menjadi pintu masuk bagi orang asing melalui pelabuhan laut, sesungguhnya Kabupaten Buleleng telah dikenal oleh wisatawan dari tahun 1920an.

Rendahnya kunjungan wisatawan di objek-objek wisata di kabupaten Buleleng, disebabkan oleh masih lemahnya sistem pemasaran. Oleh karena itu perlu dikembangkan suatu model pemasaran objek dan daya tarik wisata serta fasilitas wisata sebagai upaya untuk meningkatkan jumlah kunjungan wisatawan di kabupaten Buleleng. Morrison (2002) menjelaskan pemasaran merupakan proses yang berlangsung secara terus menerus dan 
berkelanjutan, dimana kegiatan yang terjadi di dalamnya adalah merencanakan, meneliti, mengimplementasikan, mengawasi dan melakukan penilaian dalam berbagai aktivitas yang dirancang untuk memuaskan baik kebutuhan dan keinginan pelanggan dan tujuan organisasinya. Agar kegiatan tersebut berlangsung secara efektif, maka pemasaran memerlukan usaha setiap orang dalam sebuah organisasi dan dapat dibuat kurang atau lebih efektif oleh tindakantindakan dari kelengkapan organisasi. Menyikapi berbagai permasalahan pariwisata yang dihadapai oleh Kabupaten Buleleng, maka perlu dilakukan studi untuk menghasilkan strategi-strategi yang dapat digunakan oleh pelaku pariwisata di Kabupaten Buleleng dalam meningkatkan kualitas layanan pariwisata serta jumlah kunjungan wisatawan.

\section{METODE PENELITIAN}

Penelitian ini dilakukan pada keseluruhan kabupaten Buleleng. Data dikumpulkan dengan menggunakan kuesioner, wawancara, dan observasi. Data yang telah dikumpulkan dianalisis dengan analisis SWOT serta matriks EFAS dan IFAS. Hasil analisis data penelitian ini disajikan dalam bentuk tabel dan dipaparkan secara naratif.

\section{HASIL DAN PEMBAHASAN}

\subsection{Matriks IE}

Dari hasil penyebaran angket kepada 125 orang responden, yang terdiri dari 100 orang wisatawan dan 25 orang pengelola obyek diperoleh suatu penilaian. Penilaian masing-masing indikator internal perusahaan membentuk suatu kekuatan atau kelemahan, sementara itu indikatorindikator eksternal akan menentukan peluang dan ancaman. Hal tersebut sangat tergantung dari besarnya nilai yang diberikan.

\subsection{Penentuan Kekuatan, Kelemahan, Peluang, dan Ancaman Kepariwisataan Buleleng.}

Berdasarkan analisis yang telah dilakukan sesuai dengan temuan di lapangan, kekuatan saat ini diperoleh 4 indikator (hasil yang diperoleh berada pada range 2, 51 sampai 4,00), kelemahan saat ini diperoleh 8 indikator (hasil yang diperoleh berada pada range 1,00 sampai 2,50), peluang saat ini diperoleh 8 indikator dan 4 indikator sebagai ancaman di masa mendatang. Lebih ringkas mengenai kekuatan, kelemahan, peluang, dan ancaman dapat dilihat dalam tabel 3.1 dan tabel 3.2. Melalui tabel tersebut dapat diketahui bahwa kekuatan yang paling menonjol pada faktor internal adalah adanya kegiatan dan fasilitas hotel, atraksi wisata, program konservasi terhadap alam dan aktivitas budaya masyarakat. Sedangkan kelemahan yang harus mendapat perhatian serius ada dua hal yakni kebersihan dan kurangmampuan sumber daya manusia dalam berkomunikasi dengan wisatawan asing. Sedangkan yang menjadi peluang dalam pemasaran kabupaten Buleleng yang paling menonjol adalah pengaruh perekonomian global, dampak positif terhadap pelestarian budaya lokal dan dukungan masyarakat local dalam industry pariwisata. Sedangkan untuk anacaman yang paling menonjol dan diperhatikan untuk dihindari adalah daya saing competitordan kebijakan pemerintah daerah. 
Tabel 3.1 Indikator-indikator Internal Sebagai Kekuatan dan Kelemahan kepariwisataan Buleleng saat ini

\begin{tabular}{lcc}
\hline \multicolumn{1}{c}{ INTERNAL } & NILAI & KETERANGAN \\
\hline Hotel/ tourist attraction facility & 2.94 & Kekuatan \\
Tourist attraction & 3.07 & Kekuatan \\
Cleanness & 2.48 & Kelemahan \\
$\begin{array}{l}\text { Nature conservation and cultural activities in } \\
\text { the tourist destination }\end{array}$ & 2.80 & Kekuatan \\
$\begin{array}{l}\text { The ability of staff of tourist services to } \\
\text { communicate with foreign language }\end{array}$ & 2.48 & Kelemahan \\
\hline
\end{tabular}

Tabel 3.2 Indikator-indikator Eksternal Sebagai

Peluang dan Ancaman Kondisi Kepariwisataan Buleleng Saat Ini

\begin{tabular}{lcc}
\hline \multicolumn{1}{c}{ EKSTERNAL } & NILAI & KETERANGAN \\
\hline Daya saing dengan competitor & 2.48 & Ancaman \\
Pengaruh kondisi ekonomi global & 3.24 & Peluang \\
Dukungan masyarakat local dalam & 2.96 & Peluang \\
industry pariwisata & 2.48 & Ancaman \\
Kebijakan pemerintah daerah & 2.96 & Peluang \\
Dampak positif terhadap & & \\
pelestarian budaya local & &
\end{tabular}

\subsection{IFAS dan EFAS Kepariwisataan Kabupaten Buleleng}

Analisis yang dilakukan lebih lanjut pada penelitian ini adalah penentuan skor pada masing -masing indikator. Hal itu dilakukan guna mengetahui memperoleh summary dari indikator-indikator, baik internal maupun eksternal. Skor yang diperoleh untuk kondisi kepariwisataan Kabupaten Buleleng saat ini dilihat dari factor internal sebesar 2, 65 dapat dilihat pada Tabel 3.3

Tabel 3.3 Internal Factor Analisis Summary (IFAS) Kepariwisataan Kabupaten Buleleng

\begin{tabular}{lccc}
\hline \multicolumn{1}{c}{ INTERNAL } & BOBOT & NILAI & TOTAL \\
\hline Hotel/ tourist attraction facility & 0.08 & 2.94 & 0.24 \\
Strategic location & 0.08 & 2.88 & 0.23 \\
Information about the object or hotel & 0.08 & 2.45 & 0.20 \\
Tourist attraction & 0.08 & 3.07 & 0.25 \\
Hotel programs & 0.07 & 2.37 & 0.17 \\
Reliable price & 0.08 & 2.86 & 0.23 \\
Cleanness & 0.09 & 2.48 & 0.22 \\
Local involvement & 0.08 & 2.98 & 0.24
\end{tabular}


Nature conservation and cultural activities in the tourist destination

$0.09 \quad 2.80 \quad 0.25$

The ability of staff of tourist services to communicate with foreign language

$\begin{array}{lll}0.08 & 2.48 & 0.20\end{array}$

The skill and knowledge of the staff

$\begin{array}{lll}0.08 & 2.46 & 0.20\end{array}$

Tourist service

0.09

$2.64 \quad 0.24$

$0.98 \quad 2.65$

Sementara itu skor eksternal factor kepariwisataan Kabupaten Buleleng saat ini berjumlah 2, 72. Selengkapnya disajikan dalam Tabel 3.4.

Tabel 3.4 Eksternal Factor Analysis Summary Kepariwisataan Kabupaten Buleleng

\begin{tabular}{lccc}
\hline \multicolumn{1}{c}{ EKSTERNAL } & BOBOT & NILAI & TOTAL \\
\hline Daya saing dengan competitor & 0.09 & 2.48 & 0.22 \\
Daya beli wisatawan & 0.10 & 2.80 & 0.28 \\
Pengaruh penggunaan teknologi terhadap & 0.10 & 2.60 & 0.26 \\
operational & 0.09 & 2.60 & 0.23 \\
$\begin{array}{l}\text { Pengaruh kondisi keamanan } \\
\text { Pengaruh kondisi ekonomi global }\end{array}$ & 0.09 & 3.24 & 0.29 \\
$\begin{array}{l}\text { Pengaruh kondisi perpolitikan dalam negeri dan } \\
\text { international }\end{array}$ & 0.08 & 2.20 & 0.18 \\
$\begin{array}{l}\text { Pengaruh pengembangan terhadap lingkungan } \\
\text { Dukungan masyarakat local dalam industry }\end{array}$ & 0.10 & 2.76 & 0.28 \\
pariwisata & 0.09 & 2.96 & 0.27 \\
Kebijakan pemerintah daerah & 0.09 & 2.48 & 0.22 \\
$\begin{array}{l}\text { Dampak positif terhadap pelestarian budaya } \\
\text { local }\end{array}$ & 0.09 & 2.96 & 0.27 \\
$\begin{array}{l}\text { Peranan Biro perjalanan Wisata dalam } \\
\text { meningkatkan kunjungan wisatawan }\end{array}$ & 0.08 & 2.80 & 0.22 \\
\hline
\end{tabular}

\subsection{Analisis Matriks Internal (IFAS) dan Analisis Matriks Eksternal (EFAS)}

Matriks internal dan matriks eksternal dipergunakan untuk membantu merumuskan grand strategy yang akan diterapkan, setelah mengetahui posisi dari pada kepariwisataan Kabupaten Buleleng dalam matriks tersebut. Matriks internal menjabarkan tentang pandangan responden mengenai kekuatan dan kelemahan dari pengembangan kepariwisataan di Kabupaten Buleleng, sedangkan matriks Eksternal menggambarkan peluang dan ancaman pengembangan kepariwisataan Buleleng. Tabel 3.5 menunjukkan analisis matriks internal (IFAS), sedangkan tabel 3.6 
menunjukkan analisis matriks eksternal (EFAS). Tabel dibawah menjelaskan posisi kepariwisataan Kabupaten Buleleng berada pada posisi kuat, dimana total kekuatan sebesar 1.67 lebih tinggi dibandingkan total kelemahan sebesar 0.98. Atraksi wisata (tourist attraction) yang merupakan faktor terpenting dalam pengembangan suatu daerah menjadi daerah tujuan wisata harus dipersiapkan segala sesuatunya dengan matang. Atraksi wisata sebagai inti yang mempu menarik minat wisatawan untuk berkunjung tidak dapat diabaikan atau dimanfaatkan hanya untuk kepentingan sesaat, melainkan harus dapat dikelola dengan baik sehingga dapat menjadi daya tarik pada generasi saat ini hingga generasi selanjutnya. Misalnya Pantai Lovina yang sudah dikenal tidak hanya di Indonesia melainka juga di mancanegara, harus mampu dikelola dengan baik sehingga dapat memberikan manfaat secara berkelanjutan tidak hanya pada pemerintah, namun khususnya kepada masyarakat setempat yang tinggal dan memelihara daerah ini. Dengan demikian maka dalam menjaga pantai perlu dilakukan banyak hal dan oleh banyak pihak yakni dalam menjaga sepadan pantai agar tidak dimanfaatkan sebagai tempat untuk pembangunan fasilitas wisata, menjaga kebersihan lingkungan pantai dan tidak melakukan eskploitasi pantai dalam bentuk apapun yang dapat merusak pantai itu sendiri.

Tabel 3.5 Analisis Matriks Internal (IFAS)

\begin{tabular}{lrrr}
\hline \multicolumn{1}{c}{ INTERNAL } & BOBOT & NILAI & SKOR \\
\hline KEKUATAN & & & \\
Tourist attraction & 0.08 & 3.07 & 0.25 \\
Local involvement & 0.08 & 2.98 & 0.24 \\
Hotel/ tourist attraction facility & 0.08 & 2.94 & 0.24 \\
Reliable price & 0.08 & 2.86 & 0.23 \\
Strategic location & 0.08 & 2.88 & 0.23 \\
Nature conservation and cultural activities in the tourist destination & 0.09 & 2.80 & 0.25 \\
Tourist service & 0.09 & 2.64 & 0.24 \\
\hline & & & 1.67 \\
\hline KELEMAHAN & & & \\
Information about the object or hotel & 0.08 & 2.45 & 0.20 \\
Hotel programs & 0.07 & 2.37 & 0.17 \\
Cleanness & 0.09 & 2.48 & 0.22 \\
The ability of staff of tourist services to communicate with foreign & 0.08 & 2.48 & 0.20 \\
language & 0.08 & 2.46 & 0.20 \\
The skill and knowledge of the staff & & & 0.98 \\
\hline
\end{tabular}

Begitu pula dengan data yang ada pada tabel 3.6, dapat dilihat bahwa skor peluang 2.10 lebih besar dibandingkan dengan ancaman 0.62. Berdasarkan data 
tersebut, maka pengelola pariwisata Kabupaten Buleleng harus memanfaatkan kekuatan dan peluang yang ada guna meminimalkan dampak dari kelemahan dan ancaman yang ada. Berdasarkan data yang diperoleh di lapangan peluang pemasaran pariwisata di Kabupaten Buleleng masih menjanjikan, namun tentu harus dibarengi dengan kesiapan sumber daya manusianya. Masuknya sistem globalisasi tentu menuntut siapapun untuk dapat bertahan dengan melakukan berbagai bentuk inovasi dan peningkatan kreatifitas. Satu sisi globalisasi memang membawa dampak negatif namun satu sisi juga memberikan dampak positip dimana setiap individu atau kelompok atau perusahaan memiliki hak untuk bersaing dalam menjual produk sepanjang memenuhi syarat-syarat tertentu. Dalam konteks pariwisata pasar utama yakni wisatawan cenderung memiliki sikap atau motivasi dalam berwisata yang selalu berubah sesuai dengan trend. Untuk itu, maka pelaku pariwisata harus jeli dan mampu meningkatkan kretifitasnya guna menghasilkan produk-produk wisata yang inovatif yang sesaui dengan selera konsumen. Dengan memiliki kesiapan yang matang baik dari sumber daya manusianya, sumber daya alam, sumber daya budaya, dan finansial maka pariwisata Kabupaten Buleleng akan mampu bersaing tidak hanya lingkup lokal namun juga nasional dan internasional.

Tabel 3.6 Analisis Matriks Eksternal (EFAS)

\begin{tabular}{lccc}
\hline EKSTERNAL & BOBOT & NILAI & SKOR \\
\hline PELUANG & & & \\
Pengaruh kondisi ekonomi global & 0.09 & 3.24 & 0.29 \\
Daya beli wisatawan & 0.10 & 2.80 & 0.28 \\
Peranan Biro perjalanan Wisata & 0.08 & 2.80 & 0.22 \\
Dukungan masyarakat local dalam industry & 0.09 & 2.96 & 0.27 \\
pariwisata & 0.09 & 2.96 & 0.27 \\
Dampak positif terhadap pelestarian budaya local & 0.10 & 2.76 & 0.28 \\
Pengaruh pengembangan terhadap lingkungan & 0.10 & 2.60 & 0.26 \\
Pengaruh penggunaan teknologi terhadap & 0.09 & 2.60 & 0.23 \\
operational & & & 2.10 \\
Pengaruh kondisi keamanan & & & \\
\hline & 0.09 & 2.48 & 0.22 \\
\hline ANCAMAN & 0.09 & 2.48 & 0.22 \\
Daya saing dengan competitor & 0.08 & 2.20 & 0.18 \\
Kebijakan pemerintah daerah & & & 0.62 \\
\hline $\begin{array}{l}\text { Pengaruh kondisi perpolitikan dalam negeri dan } \\
\text { international }\end{array}$ & & & \\
\hline
\end{tabular}

Dari perolehan total skor IFAS dan EFAS, dapat diketahui posisi kepariwisataan Kabupaten Buleleng dalam matriks internal eksternal yang ditunjukan dalam gambar 3.1. 


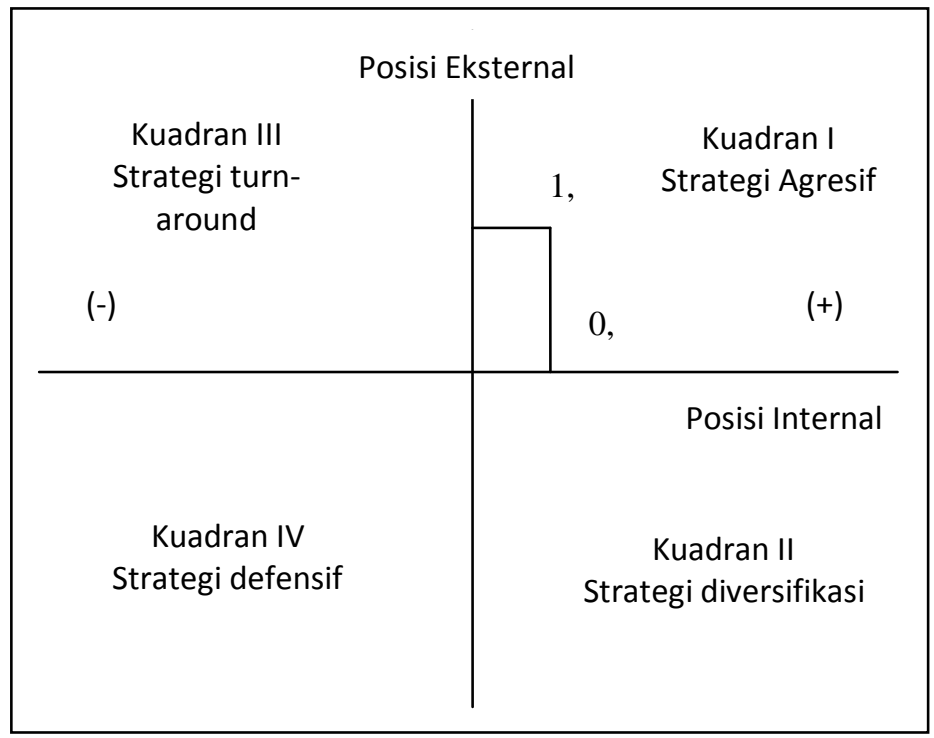

Gambar 3.1 Matriks Posisi Kepariwisataan Daerah Buleleng

Sesuai dengan model penelitian dalam rancangan penelitian formulasi strategi dibedakan menjadi dua jenis strategi, yaitu startegi utama (grand strategy) dan strategi alternative. Startegi utama didasarkan pada posisi pariwisata kabupaten buleleng pada matriks, sedangkan stratgi alternative adalah startegi alternative yang mendukung strategi utama yang terdiri atas strategi strength opportunities (SO), Strength threats (ST), weakness opportunity (WO), weakness threats (WT).

Berdasarkan pada matriks posisi yang ditunjukkan pada gambar 3.1 di atas bahwa posisi kepariwisataan buleleng berada pada kuadran I. Ini merupakan situasi yang sangat menguntungkan karena memiliki kekuatan dan peluang yang dapat dimanfaatkan guna memasarkan potensi pariwisata yang ada di Kabupaten Buleleng. Strategi yang harus diterapkan dalam kondisi ini adalah agresif. Strategi agresif merupakan strategi yang diterapkan untuk mendukung kebijakan pertumbuhan yang agresif, dimana dapat dilakukan dengan mengembangkan produk dengan memanfaatkan potensi wisata yang dimiliki oleh Kabupaten Buleleng, meningkatkan kualitas jasa yang ditawarkan serta meningkatkan akses ke pasar yang lebih luas.

\subsection{Strategi Alternatif dalam Pemasaran Pariwisata Kabupaten Buleleng}

Kekuatan, Kelemahan, Peluang dan Ancaman yang dihasilkan berdasarkan analisis SWOT dengan menggunakan matriks eksternal (EFAS) dan matriks internal (IFAS) dihasilkan beberapa strategi alternatif dalam memasarkan pariwisata Kabupaten Buleleng. alternatif strategi pemasaran yang dapat diterapkan oleh kepariwisataan Buleleng diantaranya strategi strength dan opportunity (SO), strategi strength dan threat (ST), strategi weakness dan opportunity (WO) dan strategi weakness dan threat (WT) 


\section{Strategi SO}

Strategi ini berupaya untuk memanfaatkan kekuatan yang dimiliki perusahaan untuk memperoleh peluang maksimal yang ada. Strategi yang dapat diterapkan kepariwisataan Buleleng dalam kuadran ini diantaranya:

1. Mengkemas paket wisata dalam berbagai harga dan varian. Adanya atraksi wisata yang sangat banyak tersebar di seluruh Kabupaten Buleleng, maka perlu adanya pengemasan paket wisata yang melibatkan semua tempat atraksi wisata yang ada. Pengembangan pariwisata juga perlu dilakukan secara seimbang sehingga semua daerah yang ada di Kabupaten Buleleng dapat berkembang. Perlu pengemasan paket wisata di setiap wilayah, sehingga semua daya tarik wisata yang ada dapat dikenal oleh wisatawan. Berdasarkan hasil temuan dilapangan, banyak ditemukan daya tarik wisata berupa kesenian daerah seperti tari-tarian yang belum banyak dikenal oelh umum terutama wisatawan. Untuk itu perlu adanya adanya paket wisata yang juga memasukkan seni budaya masyarakat ke dalam paket. Wisatawan selain melihat keindahan alam juga disuguhkan seni pertunjukkan yang merupakan kesenian khas daerah Kabupaten Buleleng. Untuk mampu mendatangkan wisatawan, tentu tidak lepas dari peranan pemandu wisata yakni guide yang mengantar wisatawan sampai ke tempat tujuan. Guide fee ternyata menjadi sesuatu yang sangat penting untuk mendatangkan wisatawan. Dengan adanya pemberian tips kepada pemandu wisata yang mau membawa wisatawan ke suatu objek wisata, akomodasi atau fasilitas wisata lainnya mampu membawa pengaruh baik terhadap tingkat kunjungan wisatawan. Namun sis lain, dengan adanya pemberian tips kepada pemandu wisata tentu akan mempengaruhi harga sebuah produk wisata. Oleh karenanya, perlu adanya pembedaan harga produk antara harga lokal dan harga wisatawan. Dengan pembedaan harga tersebut maka pengelola objek dan fasilitas wisata tetap bisa beroperasional karena dengan harga lokal masyarakat umum pun bisa datang dan menikmati produk wisata yang dijual, dan dengan harga wisatawan bagi siapapun yang mampu membawa tamu akan memperoleh tips sehingga dapat menjadi motivasi bagi pemandu untuk mendatangkan wisatawan sebanyak-banyaknya dan tentunya akan memberikan keuntungan bagi Kabupaten Buleleng.

2. Strategi menciptakan program yang berbasis budaya lokal dan ramah lingkungan. Berdasarkan hasil identifikasi potensi wisata yang dilakukan di Kabupaten Buleleng, daya tarik yang dimiliki oleh kabupaten Buleleng tidak kalah dengan daerah lainnya yang ada di wilayah Bali bagian selatan, sehingga produk wisata yang ditawarkan lebih beragam. Hanya saja pengelolaan dan pengembangan produknya dengan menyajikannya ke dalam bentuk program wisata belum dilakukan secara maksimal, sehingga membuat atraksi wisata yang ditawarkan terkesan monoton dan terkadang hampir sama dengan penawaran atraksi wisata di wilayah Bali bagian selatan. Kabupaten Buleleng dalam hal ini harus memproklamirkan image atau karakteristik 
kepariwisataannya sendiri sehingga mampu membedakannya dengan daerah lainnya, namun tetap pada content pengembangan pariwisata budaya yang bersendikan kebudayaan masyarakat lokal seperti yang dicanangkan oleh pemerintah daerah Bali, misalnya heritage tourism. Heritage tourism merupakan icon yang tepat untuk digunakan melihat banyaknya bangunan bersejarah peninggalan penjajah belanda yang ditemukan di kabupaten Buleleng. Dalam hal ini perlu adanya pengembangan program calendar of event yang diadakan pada tempat-tempat yang juga potensial untuk dikembangkan sebagai stage/panggung pementasan dan sekaligus dapat menjadi icon pariwisata Buleleng.

Berdasarkan temuan di lapangan, ditemukan sebuah kesenian yang merupakan seni khas Kabupaten Buleleng yakni genjek. Genjek biasanya dilakukan oleh sekelompok orang yang biasanya dilakukan oleh kaum muda mudi yang bernyanyi disertai dengan gerakan tubuh dengan posisi duduk dengan tujuan untuk bernyanyi dalam kebersamaan. Genjek sesungguhnya dikenal sebagai salah satu seni dari kabupaten Karangasem. Bermula dari acara kumpul-kumpul sambil minum arak dan tuak, beberapa orang yang sudah hilang kendali dalam artian mabuk, mereka mengeluarkan suarasuara yang tidak tentu dan akhirnya disahuti dengan yang lainnya. Kesan senang dan gembira terpancarkan dari cara mereka mengungkapkan kata-kata dengan berirama selayaknya sebuah laguu tersebut. Sebagian orang lainnya akan menirukan suara musik sebagai pelengkap dari genjek khususnya suara kendang dan kempul. Seni ini pada mulanya berkembang di daerah Bali bagian timur (Karangasem) dan selanjutnya dikenal ke seluruh bagian wilayah Bali lainnya. Bahkan di Bali utara sendiri seni ini terkadang dilengkapi dengan pementasan joged lengkap dengan alat musiknya yang dilakukan setelah para seniman Genjek selesai. Jika diperhatikan, Genjek ini mirip dengan Janger. Perbedaannya terletak pada formalitas dalam membawakannya. Janger terkesan bersifat formal dan dilakukan oleh dua kelompok lelaki dan perempuan. Dengan pembawaan tembang yang masih dalam bahasa yang sangat halus disertai musik dan tarian yang sudah diatur sedimikian rupa. Sedangkan Genjek lebih memakai bahasa seharihari yang seadanya. Namun keduanya sama-sama menyiratkan kegembiraan. Seiring dengan berjalannya waktu, seni ini berkembang dan dilakukan oleh mereka yang tidak dalam pengaruh minuman tersebut. Kata-kata yang diperdengarkan pun semakin bervariasi yang diambil dari bahasa sehari-hari masyarakat seperti: perasaan jatuh cinta/kagum dengan seorang wanita, masalah pikiran yang dialami di kantor dan yang lainnya.

Melihat perjalanan seni genjek ini, sesungguhnya genjek ini dapat dimanfaatkan sebagai promosi pariwisata Kabupaten Buleleng. Berdasarkan temuan di lapangan, seni genjek yang tergabung dalam sekaa berjumlah 35 sekaa. Dalam penelitian ini, seni genjek dijadikan sebagai seni unggulan yang bisa dipentaskan dalam pentas genjek 1000 yang dipetntaskan 
dihalaman terbuka seperti di ex pelabuhan Buleleng yang memiliki cerita sejarah yakni sebagai pintu gerbang pertama bagi wiatawan ytang masuk ke Bali. Pementasan genjek 1000 ini meniru pementasan cak yang dilakukan oleh pemerintah Kabupaten Tabanan, yang dengan pementasan cak yang fantastis akhirnya mampu mendongkrak tingkat kunjungan wisatawan ke Kabupaten Tabanan khususnya objek wisata Tanah Lot setelah pementasan cak tersebut digelar.

Pengembangan sumber daya budaya menjadi daya tarik wisata budaya tentu nantinya akan memberikan dampak positip dan dampak negatip. Maka dari itu tentu pemanfaatan sumber daya budaya dalam pengembangan pariwisata harus sesuai dengan aturan atau norma yang berlaku sehingga dampak negatip yang akan ditimbulkan dari adanya pemanfaatan sumber daya budaya dapat dihindari.

3. Strategi memanfaatkan teknologi dalam operasional sehingga mudah dalam memberikan pelayanan. Perkembangan teknologi yang semakin cepat merupakan salah satu peluang untuk memberikan kemudahan dari pengelola dalam memberikan pelayanan terhadap konsumen yang dalam hal ini adalah wisatawan. Pemanfaatan teknologi di Kabupaten Buleleng bisa dikatakan masih jauh minimnya dengan pemanfaatan teknologi yang dilakukan di wilayah Bali bagian Selatan dimana teknologi benar-benar dimanfaatkan sehingga menjadi lebih tepat guna. Hal ini terlihat dalam pemanfaatan media internet, dimana setiap hotel atau atraksi wisata memiliki web tersendiri maupun terkoordinasi dengan baik dibawah naungang suatu lembaga. Informasi yang disajikan memang benar sesuai adanya dan setiap ada perubahan akan dilakukan up-date informasi, sehingga wisatawan mendapatkan informasi yang riil terjadi di lapangan. Kondisi ini akan berimplikasi positif terhadap tingkat kepuasan konsumen, dimana kepuasan dapat tercapai apabila harapan sesuai dengan kenyataan. Selain itu untuk kegiatan operational di hotel salah satu contoh pemanfaatan teknologi adalah dalam kegiatan reservasi yang dulunya masih dilakukan secara manual sekarang dapat dilakukan secara on-line lewat web yang dibuat oleh masingmasing hotel. Utamanya untuk infromasi pariwisata perlu adanya informasi tentang objek dan daya tarik wisata yang tersebar di seluruh Kabupaten Buleleng.

Sesungguhnya Kabupaten Buleleng memiliki banyak potensi wisata, namun karena keberadaannya yang cukup jauh dari kota dan kurangnya informasi tentang keberadaan daya tarik diterima oleh pelaku pariwisata dan pemda khususnya, maka daya tarik tersebut hanya berkembang secara pribadi dan pengelolaanya tidak dilakukan secara optimal. Untuk itu perlu adanya perhatian terhadap daerah-daerah yang berpotensi untuk dikembangkan sebagai daya tarik wisata dengan tetap melibatkan peranan masyarakat sebagai pemilik daerah tersebut. Dalam penelitian ini salah satu produk yang dihasilkan adalah sistem informasi tentang objek dan daya tarik wisata yang tersebar di desa-desa pada sembilan kecamatan yang ada di Kabupaten Buleleng. Data yang terkumpul dimasukkan ke dalam sistem 
informasi pariwisata Buleleng, sehingga nantinya informasi tersebut bisa di akses oleh publik, terutama oleh wisatawan. Selain itu, bagi hotel yang tidak memiliki fasilitas internet dapat membeli informasi tentang objek dan daya tarik wisata dengan cara menginstal program ke dalam komputer yang ada di masing-masing hotel.

4. Mengembangkan program-program yang menarik dengan memberdayakan masyarakat lokal. Pariwisata merupakan alat penggerak utama dan tercepat untuk menghasilkan devisa negara. Dikembangkannya kepariwisataan di suatu daerah tidak terlepas untuk meningkatkan pertumbuhan perekonomian daerah tersebut lewat peningkatan pendapatan perkapita masyarakatnya. Beragamnya potensi wisata yang dimiliki oleh kabupaten Buleleng selayaknya dalam pengembangannya selalu melibatkan masyarakat lokal. Masyarakat lokal merupakan pemilik dari daya tarik tersebut, maka selayaknyaknyalah mereka mendapat manfaat ekonomi dari setiap pengembangan yang dilakukan di daerahnya sehingga memicu kesadaran pentingnya melestarikan daya tarik tersebut untuk kepentingan pariwisata. Selama ini peranan masyarakat terhadap pengembangan suatu objek wisata masih tergolong minim, sehingga masyarakat yang berada di dalamnya kurang memahami cara untuk menjaga objek tersebut. Selain itu juga kurangnya peranan pemerintah dalam memberikan pembinaan dan pelatihan kepada masyarakat yang berada di sekitar objek menjadikan masyarakat tidak mampu memanfaatkan potensi dirinya secara optimal. Untuk itu perlu adanya pelibatan tiga pihak dalam pengembangan suatu daerah yakni pemerintah, pihak swasta/investor dan masyarakat. Pemerintah dalam hal ini selain sebagai regulator juga bisa berperan sebagai fasilitator yakni memberi pembinaan dan pelatihan kepada masyarakat. Pihak swasta/investor sebagai penaman modal dan pemberi lapangan pekerjaan. Sedangkan masyarakat menjadi pelaku langsung layanan pariwisata yang memberikan layanan kepada wisatawan yang datang.

Berdasarkan hasil penelitian, ditemukan banyak jenis kerajinan masyarakat lokal yang berpotensi untuk dikembangkan sebagai salah satu daya tarik wisata seperti mengajak wisatawan untuk belajar menenun, belajar membuat sok kasi, belajar mengolah gula aren sehingga dengan demikian masyarakat akan lebih banyak terlibat. Selain itu, melihat trend pariwisata saat ini yakni ecotourism menjadikan program pengembangan pariwisata yang mengajak wisatawan langsung menyentuh hal yang berdekatan dengan masyarakat akan menjadi sesuatu yang menarik. Dan tentunya guide/pemandu wisata memiliki peran yang sangat penting untuk memperkenalkan tempattempat yang dikembangkan menjadi wisata budaya yang dikemas dengan kreatifitas manusia.

Pengemasan sumber daya alam dan budaya sebagai atraksi wisata tentu menuntut banyak pemikiran yang kreatif. Untuk itu perlu adanya kajian-kajian untuk menghasilkan sebuah pemikiran tentang bentuk pengemasan atraksi wisata yang menarik namun tetap 
mempertahankan budaya lokal terutama ciri khas Kabupaten Buleleng.

5. Menciptakan produk yang sesuai antara harga dan nilai yang terdapat di dalamnya (value for money). Produk yang ditawarkan oleh pemerintah Buleleng disamping harus kompetitif juga haruslah memiliki nilai yang terkandung di dalamnya. Hal ini sangat berhubungan dengan trend perjalanan wisata serta tipe wisatawan yang melakukan perjalanan wisata. Saat ini wisatawan yang melakukan perjalanan wisata menuntut adanya pengalaman di masing-masing atraksi yang dikunjungi. Semakin banyaknya pengalaman yang diberikan atau ditawarkan oleh suatu atraksi wisata maka wisatawan akan semakin senang dan puas sehingga mereka tidak akan mempermasalahkan sejumlah uang yang mereka keluarkan selama menikmati atraksi tersebut. Trend ini haruslah benar-benar diperhatikan oleh pengelola untuk menjaga keberlanjutan dari pengembangan kepariwisataan di Kabupaten Buleleng. Uang ternyata mampu bersifat fleksibel, dalam artian sejumlah uang akan sama artinya dengan sejumlah layanan yang diberikan. Ketika seorang wisatawan membeli sebuah paket wisata, maka sudah tentu ada harapan yang muncul dari dirinya dengan produk dan layanan wisata yang akan diperolehnya. Sehingga dalam membuat harga sebuah produk maka ada beberapa hal yang perlu dipertimbangkan yakni jenis produknya, kuallitas produk, kemasan produk, serta layanan dalam menjual produk wisata tersebut. Dengan demikian harga sebuah produk seharusnya mencerminkan kualitas dari produk tersebut.

\section{Strategi ST}

Strategi ini memanfaatkan kekuatan untuk menghadapi ancaman. Strategi yang dapat dilakukan kepariwisataan Daerah Buleleng di masa-masa mendatang adalah melakukan diversifikasi produk serta memperkuat potensi dan kualitas produk sehingga mampu bersaing di pasaran.

1. Diversifikasi produk. Berkembangnya kepariwisataan di suatu daerah tidak terlepas dari keberadaan potensi yang mampu dikembangkan menjadi daya tarik wisata untuk datang berkunjung. Untuk memenangkan sebuah persaingan dengan menarik perhatian pengunjung untuk datang ke kabupaten Buleleng hal yang perlu digali adalah keunikan dari produk wisata yang mampu membedakan produk wisata yang ditawarkan oleh Kabupaten Buleleng dengan daerah lainnya. Salah satu cara adalah dengan melakukan studi karakteristik potensi wisata terlebih dahulu terhadap masing-masing obyek daya tarik wisata, kemudian tentukan masih-masing arah pengembangannya yang tentunya disesuaikan juga dengan karakteristik wisatawan yang ingin dijadikan target pasar. Melakukan diversivikasi produk seperti membuat kemasan paket tur yang mengkemas beberapa potensi wisata menjadi satu rangkaian perjalanan wisata. Dalam hal ini paket wisata yang dibuat merupakan perpaduan antara objek wisata yang sudah dikenal dengan daya tarik yang belum dikenal namun memiliki keunikan dan karakteristik yang mampu menjadi daya tarik wisata. Dengan demikian selain wisata yang ditawarkan tidak 
monoton, juga dapat membantu pengembangan daerah yang memiliki potensi wisata.

Beberapa bentuk diversifikasi produk yang bisa dilakukan adalah membuat jadwal kegiatan yang dilakukan secara rutin (calendar of event). Berdasarkan penelitian yang dilakukan terdapat empat tempat yang bisa dimanfaatkan sebagai tempat pementasan seni pertunjukkan yakni Ex Pelabuhan Buleleng, Sasana Budaya, Puri Buleleng dan Monumen Tri Yudha Sakti. Dengan melakukan pementasan seni pertunjukkan khas Buleleng, diharapkan wisatawan akan lebih tertarik untuk mengunjungi Kabupaten Buleleng. Selain itu kabupaten Buleleng juga banyak memiliki makanan khas Buleleng. Melihat potensi tersebut perlu adanya pengembangan wisata kuliner. Namun, pengembangan wisata ini tentu harus dibarengi dengan adanya peranan travel agent dan guide yang bersedia membawa wisatawan. Dalam kondisi seperti ini, maka giude fee merupakan salah satu strategi yang baik untuk mempromosikan pariwisata Kabupaten Buleleng.

2. Perlu adanya peningkatan peranan pemerintah daerah. Terdapat tiga pilar penting yang berperan dalam pengembangan suatu daerah menjadi daerah tujuan wisata yakni Pemerintah, Pihak Swasta/Investor dan Masyarakat. Pemerintah daerah dalam hal ini harus mampu berperan sebagai regulator dan fasilitator. Dalam artian, pemerintah sebagai regulator mampu membuat aturan atau kebijakan yang mampu membangun pengembangan daerah secara optimal. Dan sebagai fasilitator, pemerintah daerah dalam hal ini diharapkan memberikan pembinaan dan pelatihan kepada masyarakat agar mampu menjadi sumber daya manusia yang profesional yang siap menjadi pelaku layanan langsung pariwisata.

Melihat kualifikasi sumber daya manusia yang menjadi pelaku layanan langsung di objek wisata, rumah makan dan penginapan sebagain besar masih tamat SMA/SMK dan SMP, maka perlu adanya pembinaan dan pelatihan yang bertujuan untuk meningkatkan kualitas layanan wisata. Berdasarkan temuan di lapangan, pembinaan kepada sumber daya manusia justru diberikan kepada karyawan hotel yang sudah bagus perkembangannya. Hal ini seharusnya berlaku sebaliknya, yakni pemerintah daerah bekerjasama dengan manajer HRD (Human Resources Development) untuk membuat sebuah model pembinaan dan pelatihan, dan kemudian menerapkannya kepada staff fasilitas wisata yang memiliki kualifikasi di bawah standar dan kualitas layanannya rendah. Dengan demikian maka kualitas layanan wisata dapat ditingkatkan melalui peran aktif pemerintah daerah Kabupaten Buleleng.

Disamping itu, pemerintah daerah dapat bersikap lebih proatif dalam melakukan promosi pariwisata Kabupaten Buleleng. $\mathrm{Hal}$ ini dapat dilakukan dengan cara melakukan kerjasama dengan pemerintah di tingkat yang lebih tinggi dan juga terhadap pihak swasta seperti travel agent baik di Bali maupun di luar Bali. Perlu adanya sistem informasi dan layanan pariwisata Kabupaten Buleleng yang berkualitas dan bisa diakses oleh siapapun baik di Kabupaten Buleleng, di Bali, di seluruh Indonesia bahkan hingga ke luar negeri.

Jurnal IImu Sosial dan Humaniora | 14 


\section{Strategi WO}

Dalam kuadran ini strategi yang dirancang adalah berusaha meminimalisir kelemahan dengan berusaha memanfaatkan peluang yang ada. Strategi tersebut diantaranya:

1. Peningkatan media promosi dan kemudahan pelayanan melalui penggunaan teknologi informasi. Kegiatan promosi memegang peranan yang sangat penting terhadap perkembangan kepariwisataan di kabupaten Buleleng pada khususnya. Kegiatan promosi merupakan sebuah kegiatan penyampaian informasi kepada konsumen baik itu potensial buyer maupun actual buyer. Selama ini media promosi yang rutin dilakukan oleh pemerintah kabupaten Beleleng melalui brosur yang disebarkan di masingmasing tourist information centre di kabupaten buleleng, dan melakukan promosi bersama di bawah naungan pemerintah propinsi dengan lembaga dinas pariwisata propinsi Bali, disamping membuat calender of event yang pelaksanaannya disesuaikan dengan anggaran APBD. Kegiatan promosi yang dilakukan pemerintah harusnya lebih teratur dan dilaksanakan secara bersama-sama dengan melibatkan pengelola daya tarik wisata, hotel, restaurant dan segala pihak yang mendukung keberadaan pariwisata Buleleng. Pemerintah kabupaten Buleleng juga harus bertindak proaktif dalam memanfaatkan perkembangan teknologi, salah satunya dengan menggunakan jejaring internet seperti google, atau dengan membuat web tersendiri yang berisikan profil atraksi wisata serta fasilitas wisata lengkap dengan berbagai macam informasinya, sehingga dapat lebih mudah di akses oleh wisatawan. Disamping itu media ini lebih efektif memberikan informasi dibandingkan dengan menggunakan brosur karena informasi yang ada bisa di up-date sesuai dengan kondisi terkini. Selain melalui media elektronik perlu juga dilakukan peamsaran melalui media cetak. Saat ini sudah banyak majalah pariwisata baik ruang lingkup lokal maupun internasional. Majalah pariwisata merupakan majalah yang berisikan segala hal yang berkaitan dengan pariwisata baik itu fasilitas wisata, objek wisata, kegiatan wisata, berita wisata hingga aturan berwisata. Sehingga majalah pariwisata merupakan sarana yang potensial untuk dijadikan sebagai media promosi. Dan tentunya agar tepat sasaran maka perlu pemillihan majalah yang cukup selektif, sehinngga target bisa didapat sesuai dengan perencanaan atau harapan.

2. Peningkatan kualitas SDM. Sumber daya manusia merupakan pelaku pariwisata yang memegang peranan sangat penting. Semakin bagusnya kualitas sumber daya manusia yang dimiliki oleh sebuah atraksi wisata akan memberikan keunggulan tertentu, sehingga mampu untuk bersaing dengan daya tarik wisata yang sejenis. Sumber daya manusia yang ada di kabupaten Buleleng khususnya di bidang pariwisata bisa dikatakan masih minim, hal ini terlihat dari tingkat pendidikan pengelola baik itu di daya tarik wisata maupun di hotel mayoritas lulusan SMA/SMK. Pengetahuan seperti penguasaan bahasa asing, peningkatan keterampilan dalam memberikan pelayanan terhadap wisatawan, dan pemahaman mengenai pariwisata harus 
mulai ditingkatkan, sehingga nantinya mampu memberikan pelayanan yang baik dan profesional, karena tidak terdapat kesalahpahaman akibat pemaknaan yang berbeda. Perlu adanya kerjasama antara investor dan pemerintah daerah untuk memberikan pembinaan dan pelatihan bagi sumber daya manusia yang masih memiliki kualifikasi pendidikan yang kurang dalam bentuk kursus-kursus pada bidang-bidang tertetu sesuai dengan kemampuan SDM dan kebutuhan pengembangan industri pariwisata.

Kualitas sumber daya manusia sebagai pelaku layanan pariwisata, berdasarakan paparan diatas memang masih relatif rendah. Hal ini diperkuat dengan temuan Widiastini, 2007 yang menyatakan bahwa tingkat pendidikan staff hotel dan restoran yang ada di Kabupaten Buleleng mayoritas SMP, SMA/SMK. Untuk itu perlu dirancang sebuah model pembinaan dan pelatihan kepada staff pelaku layanan langsung pariwisata yang memiliki kualitas layanan yang masih rendah dengan melibatkan peranan pemerintah daerah dan manajer di bidang HRD (Human Resources Department) sehingga luaran dari pembinaan dan pelatihan dapat bermanfaat.

3. Menjaga kebersihan lingkungan sekitar dengan mengembangkan produk yang ramah lingkungan. Berubahnya trend perjalanan wisatawan dari yang bersifat mass tourism ke alternatif tourism dan ecotourism dimana wisatawan disamping ingin memanfatkan potensi yang ada sebagai daya tarik, juga ingin potensi tersebut dilestarikan. Dengan demikian pengelola objek wisata harus berusaha memanfaatkan potensi alam dan budaya yang ada tanpa harus melakukan eksploitasi, sehingga sumber daya yang ada masih terlihat alami atau natural. Sebuah kegiatan konservasi baik itu konservasi alam maupun konservasi budaya perlu ditingkatkan dengan tujuan untuk menjaga sumber daya yang ada tidak mengalami perubahan yang besar atau justru menjadi rusak. Selain itu, kegiatan clean-up seharusnya tidak hanya dilakukan di tempat-tempat tertentu namun dilakukan di seluruh objek dan daya tarik wisata yang dilakukan oleh pengelola masing-masing. Dengan demikian, kebersihan dapat menjadi daya tarik karena dengan kondisi yang bersih wisatawan akan senang untuk datang, bahkan memilih untuk tinggal.

Saat ini sedang digencarkan Go Green, yang salah satu maknanya adalah kebersihan lingkungan harus terjaga. Menjadikan suatu daerah menjadi bersih tentu perlu adanya pelibatan seluruh pihak baik itu pengelola objek, pengelola fasilitas wisata, pemerintah daerah dan masyarakat. Kebersihan memang harus dimulai dari diri sendiri untuk bisa menjaga kebersihan diri dan kebersihan lingkungan disekitarnya. Kemudian dilanjutkan dengan kebersihan dalam kelompok-kelompok, organisasi hingga pada suatu daerah. Adanya keinginan untuk menjadi bersih merupakan hal yang utama sebelum melakukan kebersihan. Dan tentunya untuk menjadikan lingkungan yang bersih tidak hanya cukup dengan himbauan atau bahkan menyapu. Namun, tersedianya fasilitas yang memadai seperti tong sampah, toilet, alat kebersihan, dan staff kebersihan yang memadai harus selalu ada dalam 
kondisi yang baik. Untuk itu perlu adanya perencanaan yang matang dalam menciptakan suasana yang bersih terutama dalam hal penyiapan dana. Selain itu, kerjasama dengan sekolah-sekolah baik dari tingkat SD, SMP, SMA hingga Perguruan tinggi dalam hal pemeliharaan kebersihan perlu juga diciptakan. Adanya pembersihan bersama yang dilakukan secara rutin tiap akhir pekan akan mampu melatih kebiasaan seluruh masyarakat untuk menjaga kebersihan bersama. Dan untuk mengajak masyarakat mau menjaga kebersihan tentu harus ada yang memberi contoh, ini bisa dilakukan oleh tokoh-tokoh masyarakat sehingga tercipta sebuah kesan bahwa kebersihan harus dilakukan oleh siapapun baik itu masyarakat umum maupun orang yang sudah menduduki posisi tinggi.

\section{Strategi WT}

Strategi ini dirancang untuk meminimalisir kelemahan dengan menghindari ancaman yang akan timbul. Strategi yang dapat diterapkan adalah bekerja sama dengan berbagai industri terkait dan strategi efisiensi.

1. Melakukan kajian terhadap pengembangan pariwisata Kabupaten Buleleng. Selama ini dalam pengembangan kepariwisataannya Kabupeten Buleleng bekerjasama dengan berbagai pihak, baik itu lembaga pendidikan dalam melaksanakan penelitian pariwisata seperti STP Bali, dan Undiksha, serta bekerjasama dengan pemerintah provinsi Bali lewat Dinas Pariwisata Daerah khususnya dalam kegiatan promosi terpadu. Pemerintah kabupaten Buleleng, seharusnya lebih pro aktif menjalin kerjasama baik itu dengan investor asing yang menanamkan modalnya di Kabupaten Buleleng, misalnya dalam pembangunan fasilitas wisata, namun pelaksanaannya selayaknya memperhatikan kondisi lingkungan sosial budaya masyarakatnya serta daya dukung lingkungan, bekerjasama dengan pihak tour operator dalam nageri maupun luar negeri, dengan memasukkannya dalam program paket perjalanan wisata serta bekerjasama dengan organisasi-organisasi nirlaba yang aktif melakukan event-event untuk anggotanya.

Selain itu, Pemerintah daerah Kabupaten Buleleng juga seharusnya menyelekasi kajian pariwisata yang dilakukan. Dan kemudian kajian-kajian yang dilakukan tidak hanya menghasilkan sebuah laporan dan artikel yang dimasukkan ke dala jurnal. Namun, kajian yang telah dihasilkan tentu harus dimasukkan ke dalam penganggaran APBD sehingga hasil akhir dari kajian tersebut dapat direalisasikan sebagai bukti keseriusan pemerintah daerah dalam mengembangkan pariwisata. Untuk menciptakan hasil yang maksimal maka usulan kajian tentu harus dilakukan dengan sungguh-sungguh, sehingga hasil yang dilaporkan sesuai dengan keadaan di lapangan yang bersifat objektif dan dapat diterima oleh seluruh pihak yang terlibat baik itu pemerintah daerah setempat, pihak swasta maupun masyarakat. Dengan demikian, maka kajian pariwisata Kabupaten Buleleng sesuai dengan kebutuhan dan dapat bermanfaat bagi masyarakat, pihak 
swasta, dan pemerintah daerah dalam bidang penerimaan PAD.

2. Meningkatkan informasi tentang pariwisata Buleleng. Peranan informasi tentang objek dan daya tarik wisata yang up to date merupakan menjadi hal yang sangat penting. Untuk itu perlu dibangun sebuah sistem informasi yang menyuguhkan potensi wisata yang ada di seluruh Kabupaten Buleleng. Agar data menjadi lengkap, maka pendataan perlu dilakukan di setiap kecamatan dengan mencari potensi di masingmasing desa tang tersebar di setiap kecamatan. Dengan demikian, pendataan potensi objek dan daya tarik akan menjadi lengkap.

Selain melakukan pendataan potensi wisata di setiap kecamatan, perlu juga adanya sistem penerimaan informasi pariwisata yang terpusat yang nantinya bertugas untuk melanjutkan informasi yang diterima ke masyarakat umum, wisatawan, ke luar daerah hingga ke luar negeri. Dalam hal ini, adanya kajian tentang terminal Sangket sebagai pusat layanan dan informasi pariwisata Kabupaten Buleleng perlu diimplementasikan. Mengingat tempat tersebut selain berpotensi untuk dikembangkan sebagai pusat informasi dan layanan pariwisata, dan tersedia tempat yang bisa digunakan sebagai panggung pementasan. Disamping itu, berdasarkan hasil pendataan masyarakat pada tahun 2010 sebagian sopir dan masyarakat cukup antusias menerima bila daerahnya dikembangkan sebagai pusat layanan dan informasi pariwisata, dengan harapan mereka bisa terlibat/berperan sebagai pelaku layanan langsung pariwisata.
3. Kreatif terhadap produk hotel. Hotel sebagai sarana akomodasi semestinya tidak hanya menyiapkan sarana penginapan melainkan juga menyiapkan sarana lain seperti memiliki makanan yang unik atau mengadakan pementasan kesenian sehingga dapat menjadi daya tarik bagi wisatawan untuk menginap.

Menyikapi kelemahan dan ancaman yang di dapat dari hasil temuan di lapangan maka perlu adanya pengembangan model pemasaran baik bagi objek dan daya tarik wisata serta fasilitas wisata yang ada di Kabupaten Buleleng. Dalam mengembangkan model ini perlu adanya sebuah kajian yang mendalam yang dimulai dari adanya ketersediaan sumber daya dan kebutuhan wisatawan, sehingga tujuan yang diharapkan dapat dicapai.

\section{SIMPULAN}

Kabupaten Buleleng memiliki 84 objek dan daya tarik wisata yang tersebar di seluruh desa pada sembilan kecamatan. Berdasarkan sampling, data dicari dengan menggunakan kuesioner untuk mengetahui kondisi internal dan eksternal sehingga hasil yang diperoleh adalah sebuah analisis strategi Strength, Weakness, Opportunity dan Threats (SWOT). Berdasarkan olahan data, memang perlu diadakan diversifikasi produk pariwisata guna meningkatkan kunjungan wisatawan. Meskipun ekonomi global dan atraksi wisata ditentukan sebagai peluang dan kekuatan, namun ternyata guide baik yang memiliki ijin maupun tidak ternyata merupakan faktor penting yang harus diperhatikan karena dapat menjadi peluang, kekuatan bahkan juga mungkin ancaman. Kekuatan dan peluang terjadi ketika guide mampu bekerjasama dengan 
baik terhadap pengelola objek beserta fasilitas wisata disekitarnya, sehingga wisatawan mau datang dan membeli produk wisata. Namun, disisi lain peranan guide juga ternyata mampu memberikan dampak negatif yakni memungkinkan terjadinya persaingan tidak sehat dalam memberikan tips dalam jumlah yang banyak dan terjadi perlombaan dalam memenangkan hati guide, baik antar pengelola objek wisata maupun antar pengelola fasilitas wisata. Hal ini tentu harus menjadi perhatian serius, tidak hanya pengelola objek dan fasilitas wisata namun juga pemerintah yang dalam hal ini dapat dijadikan sebagai jembatan penghubung yang baik antara guide dengan pengelola objek wisata dan atau fasilitas wisata.

\section{DAFTAR PUSTAKA}

Brunt, B. 1997. Market Research in Travel and Tourism. Great Britain: Butterworth, Heinemann.

Cooper, C. et all. 2005. Tourism: Principle and Practice. Third Edition. Prentice Hall

Kotler, P. 2002. Manajemen Pemasaran. Jilid I edisi Bahasa Indonesia. Jakarta: Pearson Education Asia Ptc. Ltd. Dan PT. Prenhallindo.

Morrison, Alison J. 1994. Marketing Strategic Alliances: The Small Hotel Firm. International Journal of Contemporary Hospitality Management vol. 6:3 (Cited, 4 Mei 2008). USA: MCB University Limited.

International Journal of Contemporary Hospitality Management vol 6:3. (Cited 4 mei 2008). USA: MCB University Limited.

Morrison, M. 2002. Hospitality and Travel Marketing. Third Edition. Australia: Delmar Thompson Learning.

Noronha. 1977. Social And Cultural Dimensions Of Tourist A Review Of
Literature In English. Washington DC: World Bank.

Pitana. 2006. Kepariwisataan Bali Dalam Wacana Otonomi Daerah. Jakarta: Puslitbang Kepariwisataan.

Reid, D. Dan Bojanic, C. 2006. Marketing for Hospitality and Tourism. Second Edition. Prentice Hall International, Inc. 



\title{
PENGEMBANGAN KAMUS "CHART OF ACCOUNTS" UNTUK MATA KULIAH AKUNTANSI PERHOTELAN
}

\author{
I Putu Gede Diatmika ${ }^{1}$, Gede Adi Yuniarta ${ }^{2}$ \\ 1, 2 Jurusan Akuntansi, Fakultas IImu Sosial, Universitas Pendidikan Ganesha \\ Singaraja, Indonesia \\ e-mail:diatmika_awsy@yahoo.co.id,gdadi_ak@yahoo.co.id
}

\begin{abstract}
Abstrak
Akuntansi Perhotelan merupakan salah satu mata kuliah akuntansi terapan dalam kondisi riil di dunia kerja tepatnya implementasi di dunia pariwisata. Mata kuliah ini memiliki karakteristik yang berbeda dengan dunia usaha lainnya terutama terkait dengan sifat usaha berupa kegiatan jasa pelayanan "hospitality service" yang berorientasi profit. Chart Of Accounts dalam akuntansi perhotelan merupakan rekening-rekening Akuntansi serta istilahistilah yang merupakan komponen penting dalam penguasaan Akuntansi Perhotelan. Rekening dan istilah dalam akuntansi perhotelan sangatlah berbeda dengan akuntansi secara umum terlebih lagi saat ini informasi mengenai chart of Accounts ini belum terkoordinasi dalam satu literatur yang tepat. Tujuan jangka panjang dari penelitian ini adalah untuk menghasilkan literatur dalam bentuk kamus Chart Of Accounts untuk Akuntansi Perhotelan yang dapat dimanfaatkan dalam pembelajaran Akuntansi Perhotelan di kelas yang sekaligus juga dapat dimanfaatkan sebagai sumber informasi pemakai baik masyarakat umum maupun praktisi di di dunia perhotelan. Untuk dapat mencapai tujuan penelitian ini digunakan model pengembangan four $D$ Models yang terdiri dari 4 tahap pengembangan, yaitu Define, Design, Develop, dan Desseminate. Produk penelitian ini adalah kamus Chart of Accounts untuk Akuntansi Perhotelan.
\end{abstract}

Kata Kunci: Akuntansi Perhotelan, Chart of Accounts, Kamus

\begin{abstract}
Hotel Accounting is one of the applied accounting courses in real conditions in the world of work exactly at the implementation of tourism field. This subject has different characteristics with other businesses primarily related to the nature of the business of "hospitality service" activities which is profit-oriented. Chart of Accounts in Hotel Accounting is accounting accounts and terms which is an important component in the mastery of hotel accounting. Accounts and accounting terms in hotel accounting are very different with the general accounting; moreover, recently, information about the chart of accounts has not been coordinated in an appropriate literature. Long-term goal of this research is to produce literature in the form of a Chart of Accounts dictionary for Hotel Accounting that can be used in Hotel Accounting course in the classroom which can also be used as a source of user information both public and practitioners in hotel field. In order to achieve the objectives of the research, the development model of "four-D models" was used in this research consisted of four stages of development, including Define, Design, Develop, and Disseminate. Research product was the Chart of Accounts dictionary for Hotel Accounting.
\end{abstract}

Keywords: Chart of Accounts, Dictionary, Hotel Accounting 


\section{PENDAHULUAN}

Hotel merupakan usaha jasa pelayanan atau disebut "hospitality service" yang seluruh atau sebagian bangunan digunakan untuk pelayanan kamar, makanan, minuman serta rekreasi yang dikelola dengan tujuan komersial. Untuk itu hotel sebagai penjual jasa harus dapat menyediakan tiga hal yaitu; fasilitas yang memadai, sumberdaya manusia yang terampil untuk melayani dan pengelolaan yang profesional. Untuk memenuhi hal tersebut dengan sendirinya hotel membutuhkan biaya yang cukup besar dan mahal, baik biaya untuk menyediakan fasilitas maupun biaya untuk pengadaan sumber daya manusia yang melayani berupa gaji yang memadai dan pelatihanpelatihan yang lebih baik. Semua perhitungan untuk pembiayaan seperti gaji pegawai, transportasi, pemasaran, pembelian semua barang kebutuhan, sampai sekecil-kecilnya harus diperhitungkan secara cermat. Dan untuk mendapatkan data yang cukup akurat serta mengurusi dan mendata keluar masuknya uang maka diperusahaan hotel diperlukan satu departemen khusus yang biasa disebut Accounting Departement atau Departemen Akuntansi. Akuntansi Perhotelan merupakan syarat mutlak yang harus dikuasai oleh pegawai yang bekerja di Accounting Departement.

Dalam rangka penyiapan tenaga profesional bidang akuntansi, Jurusan Akuntansi Undiksha Singaraja memasukkan mata kuliah Akuntansi Perhotelan sebagai salah satu muatan lokal dalam struktur kurikulumnya. Akuntansi Perhotelan merupakan mata kuliah akuntansi terapan yang mengkaji perlakuan akuntansi pada sektor perhotelan. Dalam mata kuliah ini materi pembelajaran difokuskan pada sistem akuntasi perhotelan dengan salah satu komponen utamanya adalah Chart of Accounts. Chart Of Accounts dalam akuntansi perhotelan merupakan rekeningrekening Akuntansi serta istilah-istilah yang merupakan komponen penting dalam penguasaan Akuntansi Perhotelan. Namun saat ini dalam proses pembelajaran mata kuliah Akuntansi Perhotelan terbentur dengan kendala sangat minimnya literatur pendukung terutama literatur yang mampu memberikan informasi spesifik mengenai implementasi Akuntansi dalam kondisi riil di dalam usaha perhotelan termasuk litaratur mengenai chart of Accounts akuntansi perhotelan yang belum terkoordinasi dalam satu literatur yang tepat.

Tujuan dari penelitian ini adalah terwujudnya Kamus Chart of Accounts untuk Akuntansi Perhotelan yang dapat digunakan sebagai literatur dalam pembelajaran mata Kuliah Akuntansi Perhotelan di kelas yang sekaligus juga dapat dimanfaatkan sebagai sumber informasi pemakai baik masyarakat umum maupun praktisi di di dunia perhotelan. Produk penelitian ini akan mengakomodasi aspek-aspek; (1) kondisi riil kebutuhan dalam mata kuliah Akuntansi Perhotelan, (2) kelengkapan informasi yang tersaji, (3) validitas baik dari akademisi maupun praktisi perhotelan, (4) kepraktisan dan keefektifan untuk penggunaan dalam proses belajar mengajar di kelas, dan (5) kepraktisan dan keefektifan dalam penggunaan di dunia kerja.

\section{METODE}

Dalam penelitian ini akan digunakan model pengembangan perangkat pembelajaran four $D$ Models (model 4-D). Model ini terdiri dari 4 tahapan pengembangan, yaitu: Define, Design, 
Development dan Desseminate. Untuk tahun pertama lokasi penelitian ini dilakukan di Universitas Pendidikan Ganesha Singaraja, tepatnya di Jurusan Akuntansi dan lima buah hotel berbintang di Bali. Untuk tahun kedua lokasi penelitian difokuskan pada 10 hotel berbintang di Bali. Sedangkan ditahun ke tiga deseminasi dan penyempurnaan penelitian difokuskan pada beberapa Perguruan Tinggi di Indonesia. Penelitian dilakukan selama tiga tahun yaitu mulai tahun 2009 sampai dengan tahun 2011.

\section{HASIL DAN PEMBAHASAN}

\section{Resume pelaksanaan Penelitian tahun pertama}

Penelitian di Tahun I (2009) meliputi tiga tahapan yaitu: Define, Design, dan Development. Pelaksanaan Tahap Define (Pendefinisian) memiliki tujuan menetapkan dan mendefinisikan syaratsyarat kamus Chart of Accounts Akuntansi Perhotelan. Tahapan ini dilakukan dengan analisis tujuan dalam batasan rancangan kamus Chart of Accounts Akuntansi Perhotelan. Ada 5 langkah pokok dalam tahapan ini, yaitu meliputi: (a) Analisis kebutuhan kamus Chart of Accounts Akuntansi Perhotelan yang meliputi substansi, relevansi keilmuan, tantangan dan tuntutan kebutuhan di masa yang akan datang. Analisis kebutuhan ini memunculkan masalah dasar yang dibutuhkan dalam pengembangan kamus Chart of Accounts Akuntansi Perhotelan berupa belum adanya kamus sejenis dan terwujudnya kamus yang dapat digunakan baik untuk kepentingan pembelajaran maupun untuk kepentingan praktisi riil di dunia kerja, sehingga dari temuan ini dibuatkan alternatif-alternatif rancangan yang relevan. (b) Analisis pengguna kamus Chart of Accounts
Akuntansi Perhotelan, analisis ini dilakukan dengan memperhatikan ciri, tingkat pemahaman, motivasi, ketrampilan, dan pengalaman pengguna. (c) analisis tugas merupakan kumpulan prosedur untuk menentukan isi kamus Chart of Accounts Akuntansi Perhotelan dalam bentuk garis besar dengan hasil berupa ditemukannya substansi kamus yang berisikan bagan perkiraan untuk masing-masing departemen lengkap dengan deskripsi dan fungsi masing-masing. (d) analisis konsep dilakukan dengan mengidentifikasi konsepkonsep utama substansi isi dari kamus Chart of Accounts Akuntansi Perhotelan, menyusun secara sistematis dan merinci konsep-konsep yang relevan. Hasil dari analisis ini berupa peta konsep pengembangan kamus Chart of Accounts Akuntansi Perhotelan. (e) Perumusan tujuan dan kebermanfaatan produk yang menjadi dasar penyusunan, pemilihan media dan merancang kamus Chart of Accounts Akuntansi Perhotelan. Produk akhir dari tahapan ini adalah rancangan Kamus Chart of Accounts Akuntansi Perhotelan berdasarkan hasil analisis kebutuhan, tugas, konsep, tujuan dan kebermanfaatan.

Tahapan kedua yang telah dilakukan di tahun pertama adalah tahap Design (Perancangan) pada tahapan ini dilakukan perancangan prototipe kamus Chart of Accounts Akuntansi Perhotelan. Dalam tahapan ini lakukan penyusunan sistematika, pemilihan media dan pemilihan format. Pemilihan format dilakukan dengan mengkaji format-format kamus lain yang telah ada dan disesuaikan dengan kebutuhan sesuai dengan tujuan yang ingin dicapai yaitu dapat digunakan secara maksimal oleh pengguna kamus Chart of Accounts Akuntansi Perhotelan. Produk akhir tahapan ini adalah draft kamus Chart 
of Accounts Akuntansi Perhotelan. Adapun gambaran umum draft kamus Chart of Accounts Akuntansi Perhotelan adalah dari segi format disusun berbeda dengan kamus lain dalam hal ini kalau kamus-kamus kebanyakan seperti kamus Indonesia Inggris ataupun kamus lain biasanya format dibuat dua sejajar antara satu bahasa dengan terjemahannya. Sedangkan dalam kamus Chart of Accounts Akuntansi Perhotelan ini sesuai dengan tujuan yang ingin dicapai yaitu dapat digunakan secara maksimal oleh pengguna maka dibuat format dalam bentuk tiga berbaris yang meliputi description, account dan department. Kolom description berisikan diskripsi dari bagan perkiraan, kolom account berisikan nama-nama perkiraan dan kolom department berisikan dimana bagan perkiraan tersebut berada dalam departemen-departemen akuntansi.

Pada tahapan terakhir pada penelitan di tahun pertama ini adalah tahap Development (Pengembangan) dalam tahapan ini kegiatan penelitian yang dilakukan adalah: (1) validasi perangkat oleh pakar. Pakar disini meliputi pakar dari akademisi akuntansi yaitu rekan sejawat, dan pakar dari kalangan praktisi perhotelan. Hasil dari validasi oleh pakar digunakan untuk merivisi produk. (2) pelaksanaan simulasi yaitu memanfaatkan Kamus Chart of Accounts Akuntansi Perhotelan dalam kelompok kecil yang dilakukan terpisah yaitu dalam kelompok mahasiswa Jurusan Akuntansi Undiksha Singaraja dan kelompok praktisi perhotelan yang berasal dari 5 hotel berbintang di Bali akhir dari kegiatan simulasi ini diikuti dengan revisi produk. Hasil dari simulasi penggunaan Kamus Chart of Accounts Akuntansi Perhotelan dalam kelompok kecil mahasiswa menghasilkan bahwa secara garis besar draft kamus yang dihasikan sangat praktis dalam penggunaan, sangat informative digunakan dalam mata kuliah akuntansi perhotelan, dan format baru yang disajikan sangat membantu kemudahan dalam memperoleh informasi bagan perkiraan dan departemen dalam akuntansi perhotelan. Sedangkan simulasi yang dilakukan dengan praktisi perhotelan menghasilkan gambaran bahwa secara umum sistematika penyajian sangat praktis dalam memperoleh informasi namun masih ada beberapa kekurang lengkapan dalam hal isi terutam terkait perkiraan spesifik dalam produk tertentu yang mencirikan kekhasan dari masing-masing hotel. (3) Uji coba pemanfaatan Kamus Chart of Accounts Akuntansi Perhotelan dalam kegiatan pembelajaran yang sesungguhnya di kelas. Pada uji coba ini dilakukan simulasi penggunaan kamus pada pembelajaran sesungguhnya dengan jumlah peserta sebanyak 38 orang. Pemanfaatan kamus digunakan dalam proses pembelajaran digunakan sebagai sarana pendukung dalam penguasaan substansi perkuliahan. Kebermanfaatan kamus diuji dengan penyebaran kuisioner ke peserta kuliah dengan hasil secara general dapat disimpulkan bahwa sebagian peserta kuliah merasa sangat puas dengan pemanfaat draft kamus dalam pembelajaran mata kuliah akuntansi perhotelan.

\section{Resume pelaksanaan Penelitian Tahun Kedua}

Penelitian di tahun kedua difokuskan pada penyempurnaan Draft kamus Chart of Accounts Akuntansi Perhotelan. Penyempurnaan dilakukan dengan kegiatan desminasi pada 10 hotel berbintang di Bali. Deseminasi dilakukan dengan membagikan Draft kamus Chart of 
Accounts Akuntansi Perhotelan kepada para praktisi perhotelan di 10 hotel berbintang. Praktisi disini adalah para manager akuntansinya. Berdasarkan hasil kuisioner yang disebar menunjukkan persepsi praktisi akuntansi pada dimensi bukti langsung (tangiable) menunjukkan 60\% responden menyatakan sistematika penyajian draft kamus Chart of Accounts Akuntansi Perhotelan sangat layak, $20 \%$ menyatakan layak dan sisanya sebanyak $20 \%$ menyatakan kurang layak. Dalam hal penyajian format draft kamus Chart of Accounts Akuntansi Perhotelan40 \% menyatakan sangat layak, $50 \%$ menyatakan layak dan sisanya $10 \%$ menyatakan layak. Untuk dimensi yaitu ukuran draft kamus Chart of Accounts Akuntansi Perhotelan sebanyak $80 \%$ responden menyatakan sangat layak dan 20 $\%$ menyatakan layak. Sedangkan untuk kondisi fisik draft kamus Chart of Accounts Akuntansi Perhotelan secara keseluruhan $70 \%$ menyatakan sangat layak dan sisanya $30 \%$ menyatakan layak.

Persepsi praktisi akuntansi pada dimensi keandalan (reliability) menunjukkan untuk relevansi isi dengan kondisi kerja sebanyak $40 \%$ responden menyatakan sangat layak dan sisanya sebanyak $60 \%$ menyatakan layak. Persepsi praktisi akuntansi pada dimensi daya tanggap (responsiviness) menunjukkan untuk kesesuaian isi materi draft kamus Chart of Accounts Akuntansi Perhotelan dengan kondisi kerja terkini adalah sebanyak $40 \%$ responden menyatakan sangat layak, sebanyak $50 \%$ menyatakan layak dan ada sebanyak $10 \%$ menyatakan kurang layak. Sedangkan daya tanggap draft kamus Chart of Accounts Akuntansi Perhotelan akan pemanfaatan perkembangan teknologi sebanyak $10 \%$ menyatakan sangat layak
$90 \%$ yang menyatakan layak. Sedangkan terkait dengan kepraktisan dalam kemudahan memahami isi sebanyak $20 \%$ menyatakan sangat layak, $60 \%$ menyatakan layak namun ada juga sebesar $20 \%$ yang menyatakan kurang layak. Persepsi praktisi akuntansi pada dimensi jaminan (assurance) menunjukkan untuk keaslian isi dalam hal belum pernah membaca kamus Chart of Accounts Akuntansi Perhotelan sebanyak $70 \%$ responden menyatakan sangat layak, dan sebanyak 30\% menyatakan layak.Terkait dengan jaminan kesesuaian dengan Standar Akuntansi Keuangan, $60 \%$ menyatakan sangat layak dan sisanya $40 \%$ menyatakan layak.

\section{Hasil Penelitian Tahun Ketiga}

Penelitian di tahun ketiga difokuskan pada penyempurnaan Draft kamus Chart of Accounts Akuntansi Perhotelan. Penyempurnaan dilakukan dengan kegiatan desminasi pada 3 perguruan tinggi yaitu: Universitas Udayana, Universitas Negeri Malang dan Universitas Pendidikan Ganesha. Deseminasi dilakukan dengan membagikan Draft kamus Chart of Accounts Akuntansi Perhotelan kepada mahasiswa akuntansi di tiga perguruan tinggi tersebut, kemudian dilakukan presentasi tentang produk penelitian dan terakhir dilanjutkan dengan simulasi penggunaan produk penelitian. Setelah itu para mahasiswa diberikan kuisioner yang berisikan perspektif mereka terhadap Draft kamus Chart of Accounts Akuntansi Perhotelan. Persepsi dari para mahasiswa diharapkan akan memberikan masukan dalam rangka perbaikan produk kamus Chart of Accounts Akuntansi Perhotelan.

Perspektif mahasiswa dari ke tiga perguruan tinggi tersebut dijabarkan 
kedalam empat dimensi kualitas yaitu: (a)Bukti langsung (tangible) yaitu berupa penampakkan fisik yang meliputi sistematika penyajian, format-format, ukuran kertas, dan kondisi fisik buku lainnya.; (b) keandalan (reability) yaitu terkait dengan substansi kamus di dalam menyajikan materi yang sesuai dengan substansi keilmuan dan kondisi riil di dunia; (c) daya tanggap (responsiveness) yaitu kesediaan, kesiapan dan kemampuan kamus di dalam memberikan informasi/kemudahan memahami maksud yang terkandung di dalam draft kamus Chart of Accounts Akuntansi Perhotelan; (d) jaminan (assurance) menyangkut jaminan atas keaslian materi dalam draft kamus Chart of Accounts Akuntansi Perhotelan serta jaminan atas materi yang terkandung up to date dan sesuai kondisi riil dunia kerja dan juga sesuai dengan pedoman Standar Akuntansi Keuangan (SAK).

Berdasarkan hasil kuisioner yang disebar menunjukkan pada dimensi bukti langsung (tangiable) menunjukkan 65\% responden menyatakan sistematika penyajian draft kamus Chart of Accounts Akuntansi Perhotelan sangat layak, $23 \%$ menyatakan layak dan sisanya sebanyak 12 $\%$ menyatakan kurang layak. Dalam hal penyajian format draft kamus Chart of Accounts Akuntansi Perhotelan 41\% menyatakan sangat layak, 54\% menyatakan layak dan sisanya $5 \%$ menyatakan layak. Untuk dimensi yaitu ukuran draft kamus Chart of Accounts Akuntansi Perhotelan sebanyak $74 \%$ responden menyatakan sangat layak dan $26 \%$ menyatakan layak. Sedangkan untuk kondisi fisik draft kamus Chart of Accounts Akuntansi Perhotelan secara keseluruhan $83 \%$ menyatakan sangat layak dan sisanya $17 \%$ menyatakan layak.
Persepsi pada dimensi keandalan (reliability) menunjukkan untuk relevansi isi dengan kondisi kerja sebanyak 47\% responden menyatakan sangat layak dan sisanya sebanyak $53 \%$ menyatakan layak. Persepsi pada dimensi daya tanggap (responsiviness) menunjukkan untuk kesesuaian isi materi draft kamus Chart of Accounts Akuntansi Perhotelan dengan kondisi kerja terkini adalah sebanyak $32 \%$ responden menyatakan sangat layak, sebanyak 64\% menyatakan layak dan ada sebanyak $4 \%$ menyatakan kurang layak. Sedangkan daya tanggap draft kamus Chart of Accounts Akuntansi Perhotelan akan pemanfaatan perkembangan teknologi sebanyak 5\% menyatakan sangat layak $95 \%$ yang menyatakan layak. Sedangkan terkait dengan kepraktisan dalam kemudahan memahami isi sebanyak $7 \%$ menyatakan sangat layak, $82 \%$ menyatakan layak namun ada juga sebesar $11 \%$ yang menyatakan kurang layak.

Persepsi pada dimensi jaminan (assurance) menunjukkan untuk keaslian isi dalam hal belum pernah membaca kamus Chart of Accounts Akuntansi Perhotelan sebanyak $64 \%$ responden menyatakan sangat layak, dan sebanyak 36\% menyatakan layak. Terkait dengan jaminan kesesuaian dengan Standar Akuntansi Keuangan, $52 \%$ menyatakan sangat layak dan sisanya $48 \%$ menyatakan layak. Sedangkan untuk Indeks Kepuasan menunjukkan hasil deseminasi menyatakan bahwa draft kamus Chart of Accounts Akuntansi Perhotelan sangat layak untuk digunakan.

Berdasarkan hasil penelitian maka ada beberapa hal yang dapat dibahas dalam penelitian ini diantaranya terkait dengan isu penelitian tentang masalah pentingnya penelitian ini dilakukan adalah secara umum 
akuntansi dapat didefinisikan sebagai suatu proses pengidentifikasian, pengukuran, dan pelaporan informasi ekonomi untuk memungkinkan adanya penilaian dan keputusan yang jelas dan tegas bagi mereka yang menggunakan informasi tersebut (Soemarso, 1999:5). Sedangkan definisi akuntansi yang dikeluarkan oleh American Institute Of Certified Public Accountants (AICPA) akuntansi merupakan suatu kegiatan jasa yang fungsinya adalah menyediakan data kuantitatif, terutama yang mempunyai sifat keuangan dari satu kesatuan ekonomi yang dapat digunakan dalam pengambilan keputusan - keputusan ekonomi dalam memilih alternatif - alternatif dari suatu keadaan (Zaki Baridwan:1990:1) Dari penjelasan ini maka pengertian akuntansi tersebut bila dikaitkan dengan implementasi di dunia perhotelan maka dapat dilihat dari dua sudut yaitu: (1) dari sudut pemakai akuntansi perhotelan merupakan suatu disiplin yang menyediakan informasi yang diperlukan untuk melaksanakan kegiatan secara efisien dan mengevaluasi kegiatan- kegiatan perhotelan yang digunakan untuk membuat perencanaan yang efektif, pengawasan, pengambilan keputusan oleh manajemen dan pertanggungjawaban pengelolaan pada investor, kreditur, badan pemerintah, donatur dan sebagainya, (2) dari sudut proses kegiatan: akuntansi perhotelan merupakan suatu proses pencatatan, penggolongan, peringkasan, pelaporan dan penganalisaan data keuangan suatu organisasi perhotelan. Produk akhir dari akuntansi perhotelan adalah laporan keuangan hotel yang dimanfaatkan; (1) untuk memberikan informasi keuangan yang dapat dipercaya mengenai sumber - sumber ekonomi dan kewajiban serta modal suatu hotel, (2) untuk memberikan informasi yang dapat dipercaya mengenai perubahan dalam sumber - sumber ekonomi yang timbul akibat aktivitas yang dilakukan., (3) untuk memberikan informasi keuangan yang membantu para pemakai laporan keuangan untuk mengestimasi potensi hotel dalam menghasilkan keuntungan, (4) untuk mengungkapkan sejauh mungkin informasi lain yang berhubungan dengan laporan keuangan yang relevan untuk kebutuhan pemakai. Sedangkan yang menggunakan informasi akuntansi tersebut adalah; (1) Manajemen dalam hal ini manajemen hotel menggunakan laporan keuangan untuk menyusun program kerja, mengevaluasi kemajuan yang dicapai dalam mencapai tujuan, melakukan tindakan tindakan koreksi yang diperlukan dan sebagai salah satu sarana pertanggungjawaban, (2) Karyawan Hotel memerlukan informasi keuangan untuk mengetahui keadaan keuangan hotel, mengetahui kinerja organisasi serta untuk menyikapi pertanggungjawaban pengelola. (3) Pemilik Hotel memerlukan informasi keuangan untuk mengetahui kinerja hotel, digunakan sebagai dasar perencanaan investasi berikutnya, (4) Pemerintah memerlukan informasi keuangan terutama untuk control dan kebijakan berikutnya, (5) Calon debitur dan debitur memerlukan informasi keuangan sebagai dasar pertimbangan pemberian kredit dan mengevaluasi kredit yang sudah diberikan, dan (6) masyarakat umum lainnya yang dapat digunakan untuk kepentingan penelitian, komparatif dan perkembangan perekonomian. Untuk dapat mencapai tujuan akuntansi perhotelan maka diperlukan suatu pemahaman Sistem Akuntansi Perhotelan. Sistem akuntansi perhotelan merupakan organisasi formulir, catatan, dan laporan yang dikoordinasi sedemikian rupa untuk menyediakan 
informasi keuangan yang dibutuhkan oleh manajemen guna memudahkaan pengelolaan hotel. Komponen utama dari sistem akuntansi perhotelan adalah Chart of Accounts akuntansi perhotelan yang merupakan kumpulan dari perkiraanperkiraan dan istilah dari akuntansi perhotelan yang saling terkait dalam pembentukan suatu sistem akuntansi perhotelan. Untuk dapat memahami akuntansi perhotelan jelaslah harus dapat memahami Chart of Accounts akuntansi perhotelan.

Terkait dengan temuan penelitian ada beberapa hal yang menjadi temuan penelitian diantaranya (1) belum adanya kamus sejenis terkait dengan kamus Chart of Accounts Akuntansi Perhotelan, (2) belum adanya literatur sejenis yang dapat digunakan baik untuk kepentingan pembelajaran maupun untuk kepentingan praktisi riil di dunia kerja, (3) ditemukannya substansi kamus yang berisikan bagan perkiraan untuk masing-masing departemen lengkap dengan deskripsi dan fungsi masing-masing, (4) terwujudnya draft kamus Chart of Accounts Akuntansi Perhotelan yang dari segi format disusun berbeda dengan kamus lain dalam hal ini kalau kamus-kamus kebanyakan seperti kamus Indonesia - Inggris ataupun kamus lain biasanya format dibuat dua sejajar antara satu bahasa dengan terjemahannya. Sedangkan dalam kamus Chart of Accounts Akuntansi Perhotelan ini sesuai dengan tujuan yang ingin dicapai yaitu dapat digunakan secara maksimal oleh pengguna maka dibuat format dalam bentuk tiga berbaris yang meliputi description, account dan department. Kolom description berisikan diskripsi dari bagan perkiraan, kolom account berisikan nama-nama perkiraan dan kolom department berisikan dimana bagan perkiraan tersebut berada dalam departemen-departemen akuntansi, (5) secara umum sistematika penyajian sangat praktis dalam memperoleh informasi namun masih ada beberapa kekurang lengkapan dalam hal isi terutama terkait perkiraan spesifik dalam produk tertentu yang mencirikan kekhasan dari masing-masing hotel (6) sedangkan untuk pemanfaatan kamus dalam proses pembelajaran secara general dapat dikatakan bahwa sebagian peserta kuliah merasa sangat puas dengan pemanfaat draft kamus dalam pembelajaran mata kuliah akuntansi perhotelan.

Berdasarkan hasil penelitian perspektif dijabarkan kedalam empat dimensi kualitas yaitu: (a)Bukti langsung (tangible) yaitu berupa penampakkan fisik yang meliputi sistematika penyajian, formatformat, ukuran kertas, dan kondisi fisik kamus lainnya.; (b) keandalan (reability) yaitu terkait dengan substansi kamus Chart of Accounts Akuntansi Perhotelan di dalam menyajikan materi yang sesuai dengan substansi keilmuan dan kondisi riil di dunia; (c) daya tanggap (responsiveness) yaitu kesediaan, kesiapan dan kemampuan kamus Chart of Accounts Akuntansi Perhotelan di dalam memberikan informasi/kemudahan memahami maksud yang terkandung di dalam kamus; (d) jaminan (assurance) menyangkut jaminan atas keaslian materi dalam kamus serta jaminan atas materi yang terkandung up to date dan sesuai dengan pedoman Standar Akuntansi Keuangan (SAK). Berdasarkan hasil analisis data maka kamus Chart of Accounts Akuntansi Perhotelan sangat layak untuk digunakan.

Berdasarkan temuan- temuan yang diperoleh dalam penelitian ini maka ada beberapa hal yang perlu untuk di-justifikasi diantaranya terkait dengan belum adanya 
kamus sejenis terkait dengan kamus Chart of Accounts Akuntansi Perhotelan memang suatu kenyataan bahwa memang belum ada produk sejenis hal ini terjadi karena memang secara komersial produk sejenis memang hanya memiliki pasar terbatas khusus bagi orang yang berkecimpung dalam akuntansi perhotelan saja sehingga ini salah satu factor penyebab belum adanya kamus sejenis hal ini juga berimplikasi dengan belum adanya literatur sejenis yang dapat digunakan baik untuk kepentingan pembelajaran maupun untuk kepentingan praktisi riil di dunia kerja.

Sedangkan dengan terwujudnya draft kamus Chart of Accounts Akuntansi Perhotelan yang dari segi format disusun berbeda dengan kamus lain hal ini terkait karanteristik yang sangat spesifik dari akuntansi perhotelan sehingga diperlukan juga format khusus sesuai dengan kebutuhan dan hal itu diwujudkan dalam bentuk tiga berbaris yang meliputi description, account dan department. Kolom description berisikan diskripsi dari bagan perkiraan, kolom account berisikan namanama perkiraan dan kolom department berisikan dimana bagan perkiraan tersebut berada dalam departemen-departemen akuntansi.

Terkait dengan substansi isi memang draft kamus Chart of Accounts Akuntansi Perhotelan belum sempurna sehingga masih ada beberapa kekurang lengkapan dalam hal isi terutama terkait perkiraan spesifik dalam produk tertentu yang mencirikan kekhasan dari masingmasing hotel hal ini memang akan terjadi karena masing-masing hotel juga memiliki cirri khas masing-masing dengan produk yang khas sesuai dengan ciri mereka ini juga akan berpengaruh pada perkiraan- perkiraan yang ada sebagian kecil akan berbeda antara masing-masing hotel.

Berdasarkan hasil penelitian dan pembahasan maka ada beberapa hal yang dapat dijadikan implikasi penelitian diantaranya walaupun kamus Chart of Accounts Akuntansi Perhotelan memiliki pangsa pasar yang sangat spesifik tetapi dalam rangka pengembangan ilmu pengetahuan dan pembelajaran kamus ini memang layak untuk dilanjutkan pengembangannya mengingat belum ada produk sejenis dan sangat diperlukan dalam dunia praktisi dan pembelajaran. Apalagi berdasarkan analisis data terhadap persepsi pengguna saat deseminasi menunjukkan kamus Chart of Accounts Akuntansi Perhotelan ini sangat layak untuk digunakan.

\section{SIMPULAN DAN SARAN}

Berdasarkan hasil penelitian dan pembahasan maka dapat diperoleh kesimpulan bahwa serangakaian pelaksanaan pengembangan kamus Chart of Accounts Akuntansi Perhotelan untuk pelaksanaan di tahun 2009 s/d 2011 telah menghasikan kamus Chart of Accounts Akuntansi Perhotelan yang sudah diujicobakan dalam proses pembelajaran dengan hasil secara general sebagian peserta kuliah merasa sangat puas dengan pemanfaat draft kamus dalam pembelajaran mata kuliah akuntansi perhotelan, pemanfaatan kamus oleh para praktisi akuntansi perhotelan juga menunjukkan sangat layak dengan keberadaan kamus ini dan yang terakhir terkait dengan hasil deseminasi juga menunjukkan hasil yang sangat layak. Dan untuk tahapan penelitian lebih lanjut walaupun kamus Chart of Accounts Akuntansi Perhotelan memiliki pangsa pasar yang sangat spesifik tetapi 
dalam rangka pengembangan ilmu pengetahuan dan pembelajaran kamus ini memang layak untuk dilanjutkan pengembangannya seiring dengan perkembangan teknologi, mengingat belum ada produk sejenis dan sangat diperlukan dalam dunia praktisi dan pembelajaran.

\section{DAFTAR PUSTAKA}

AL. Haryono Jusup.2001. Dasar - dasar Akuntansi. Jilid 1. Yogyakarta: Bagian Penerbitan STIE YKPN.

AL. Haryono Jusup.2001. Dasar - dasar Akuntansi, Jilid 2. Yogyakarta: Bagian Penerbitan STIE YKPN.

Anis Chariri, Imam Ghozali. 2003. Teori Akuntansi. Edisi Revisi, Semarang: Badan penerbit Universitas Diponegoro

Arens, Alvin A, Randal J. Elder and Mark S. Beasley. 2003. Auditing and Assurance Service an Integrated Approach. Ninth Edition. New Jersey: Person Education Inc.

Arens, Alvin A dan James K. Loebbecke. 1994. Auditing Pendekatan Terpadu. [Adaptasi: Amir Abadi Jusuf]. Jakarta: Salemba Empat.

Arnyana. 2006. Model- model Pengembangan Perangkat Pembelajaran, Makalah yang disampaikan dalam Lokakaraya Model-model pembelajaran Unit P3AI IKIP Negeri Singaraja

Dahar, Ratna Wilis. 1996. Teori-Teori Belajar. Jakarta: Erlangga

Gagne, R M.; Briggs, Leslie J.; dan Wager, Walter W. 1988. Principles of Instructional Design. 3rd. Edition, New York: Holt Rinehart and Winston, Inc.

Hansen, Mowen. 2004. Management Accounting. Jakarta: Salemba Empat

Hendriksen, Eldon. S. (Marianus Sinaga, Editor). 1996. Teori Akuntansi. Edisi ke- 4. Jakarta: Erlangga.
Hendriksen, Van Breda. 2000. Teori Akunting. Edisi Kelima. Batam: Penerbit Interaksa

Ibrahim, M. 2001. Model Pengembangan Perangkat Pembelajaran Menurut Kemp \& Thiagarajan. Surabaya: Universitas Negeri Surabaya

Ikatan Akuntan Indonesia. 2002. Standar Akuntansi Keuangan. Jakarta: Salemba Empat.

Universitas Pendidikan Ganesha Singaraja. 2006. Profil Jurusan Akuntansi

Imam Ghozali, John Castellan. 2002. Statistik Non Parametrik. Semarang: Badan Penerbit Universitas Diponegoro

Kam, Vernon. 1990. Accounting Theory. Second Edition. John Wiley and Sons Inc.

Keiso, Donald E dan Weygad, Jerry J. 1995. Intermediate Accounting. Edisi ke-10 Jakarta: Penerbit Erlangga.

Knirk, F.G and Gustafon, K.L. 1986. Instructional Technology: A Systematic Approach To Education. New York: CBS College Publishing

Kusnadi, Lukman Syamsuddin, Kertahadi. 2001. Teori Akuntansi. Malang: Universitas Brawijaya

Mulyadi.1997. Sistem Informasi Akuntansi. Yogyakarta: BPFE

Soemarso S.R. 1999. Akuntansi Suatu Pengantar, Buku satu. Jakarta: Rineka Cipta.

Soemarso S.R. 1999. Akuntansi Suatu Pengantar. Buku dua. Jakarta: Rineka Cipta

Sugiyono, Eri Wibowo. 2004. Statistika untuk Penelitian. Jakarta: Alfabeta. 


\title{
MODAL SOSIAL DALAM PENGINTEGRASIAN ETNIS TIONGHOA PADA MASYARAKAT DESA PAKRAMAN DI BALI
}

\author{
I W Mudana \\ Jurusan Pendidikan Sejarah, Fakultas IImu Sosial, Universitas Pendidikan Ganesha \\ Singaraja, Indonesia \\ e-mail: wayanmudana75@yahoo.co.id
}

\begin{abstract}
Abstrak
Penelitian ini bertujuan mengungkapkan tentang modal sosial dalam pengintegrasian etnis Tionghoa pada masyarakat desa pakraman di Bali yang di dalamnya mencakup tentang kemultietnikan masyarakat desa pakraman, pola pemukiman etnis Tionghoa, jaringan hubungan sosial etnis Tionghoa dengan anggota masyarakat desa pakraman, bentuk-bentuk integrasi etnis Tionghoa dengan anggota masyarakat desa pakraman, model kontrol sosial yang dikembangkan guna mempertahankan integrasi antar etnik pada desa pakraman. Kajian terhadap hal itu akan dilakukan dengan pendekatan kualitatif. Berdasarkan atas hal itu terungkap bahwa masyarakat desa pakraman di Bali merupakan masyarakat multietnik. Pola pemukiman etnis Tionghoa pada umumnya di pusat aktivitas ekonomi, jalur utama dancendrung berbaur dengan etnis lainnya. Jaringan hubungan sosial yang dikembangkan ada yang didasarkan atas kedekatan tempat tinggal, kekerabatan, kepentingan sosial, ekonomi, budaya dan politik.Bentuk integrasi sosialnya dalam bentuk perkawinan, hubungan pertetanggaan/ hubungan tempat tinggal, persekutuan/perkumpulan./organisasi sosial baik yang berbasis sosial maupun budaya. Model kontrol sosial yang dikembangkan berupa penanaman nilai melalui sosialisasi, pemanfaatan sistem sosial keluarga/kuren, desa pakraman, kelembagaan formal lainnya, dan dengan pemanfaatan budaya fisik seperti surat, telpon, radio, pengeras suara. Di samping itu juga menggunakan bahasa. Dengan kata lain kontrol sosial dalam pemeliharaan modal sosial dan integrasi antar etnik dilakukan secara sekala dan niskala.
\end{abstract}

Kata kunci: modal sosial, integrasi, desa pakraman 


\begin{abstract}
This study aims to know the social capital in integration of Chinese ethnic at community in Pakraman village, the Chinese ethnic's settlement pattern, the nets of Chinese ethnic's relationship with the member of Pakraman village, the shapes of Chinese ethnic integration with the members of Pakraman village, social control model, that is developed for defending integration of inert ethnics in Pakraman village. The analyze that matter will be carried out, with qualitative approach. According of the matter, it is known that communities of Bali Pakraman village, consist of multiethnic society. The settlements of Chinese ethnics are generally at the centre of economic activity, at the main space and there are inclined by the other ethnic. The nets of social connection that is developed, some of them are; base on nearness settlements, genetic relationship, social interest, economic, culture and politics. The shape of their social integration in marriage shape, neighborhood relation, settlements relation, social group, organization, federation, those have a social base or culture. The model social control, which is developed, there is a value investment through socialization, benefit of system of family/kuren social, Pakraman village, the other of formal institution and by benefit physique culture, such as letter, telephone, radio, loud speaker. In the other side, there is also by using language. By the other word social control in controlling social capital and integrating inter ethnic is carried out by niskala and skala system.
\end{abstract}

Keywords: social capital, integration, pakraman village.

\section{PENDAHULUAN}

Daerah Bali pada dasarnya merupakan suatu daerah yang bersifat terbuka. Keterbukaan Bali terhadap masyarakat lainnya, dapat dibuktikan dengan adanya berbagai peninggalan sejarah, baik dari jaman pra sejarah maupun dari jaman sejarah (Kartodirjo, 1975; Ardika, 1989). Hubungan dengan dunia luar terus dimantapkan, hal ini tampak dari semakin berkembangnya hubungan kebudayaan, perdagangan, dan politik dengan negaranegara lain (Agung, 1989). Kehadiran berbagai kelompok etnis pada masyarakat Bali tidak jarang diwarnai dengan penampakan ciri-ciri kultur etnisnya dan bersifat eklusif dalam satu perkampungan tertentu, seperti Kampung Cina, Kampung Jawa, Kampung Bugis, Kampung Arab dan lain sebagainya. Hal itu dimaksudkan bukan saja dalam rangka memudahkan untuk mengenalinya, tetapi juga sebagai suatu strategi dalam mempertahankan identitas sosiokultural dan untuk menciptakan keamanan sosial.
Mereka umumnya menetap di daerah pusat-pusat aktivitas ekonomi seperti pasar dan pelabuhan, sebagaimana dikemukakan oleh Koentjaraningrat (1982) yang menyatakan bahwa sejak beberapa abad lamanya kota-kota pelabuhan kuno di Aceh, di Semenanjung Malaka, di daerah pantai Jawa Utara, dan banyak tempat lain di Indonesia telah mempunyai segolongan pedagang Tionghoa. Di Bali pada abad ke 19 Geertz menyatakan bahwa orang Cina memainkan peranan penting dalam aktivitas perdagangan pada kerajaan-kerajaan yang ada di Bali (2000). Kehadirannya sejak mula pertama sampai pada pendatang berikutnya di kepulauan Nusantara, memang telah menimbulkan berbagai permasalahan (Hendarti, 1975). Hal ini disebabkan oleh adanya sikap beberapa kalangan masyarakat Cina yang enggan melakukan proses integrasi dengan masyarakat setempat. (Burhanuddin, 1988).

Kenyataan tersebut nampaknya sangat berbeda dengan fenomena yang terjadi di Bali, terbukti dengan harmonis dan 
terintegrasinya hubungan antara masyarakat Tionghoa dengan masyarakat setempat. Kondisi tersebut diperkuat dengan terjadinya perkawinan antar etnis Bali dengan etnis Tionghoa, dan masuknya mereka dalam berbagai kelembagaan sosial keagamaan. Bahkan diantara mereka ada yang sampai menjadi pemangku di Desa Pekraman. Walaupun demikian bukan berarti mereka telah sepenuhnya kehilangan identitas sebagai etnis Tionghoa.

Fenomena tersebut telah menarik berbagai kalangan untuk mengkajinya. Sebagaimana terbukti dari adanya berbagai kajian tentang Etnis Tionghoa di Indonesia, seperti misalnya: Ratna Hindarti meneliti tentang "Perbedaan Orientasi Nilai Budaya Antara Generasi Muda dan Orang Tua Golongan Keturunan Cina" (1975). Koentjaraningrat, mengkaji tentang "Lima Masalah Integrasi Nasional" (1982).. Onghokham membahas tentang "Refleksi Seorang Peranakan Mengenai Sejarah Cina-Jawa" (1983). Jurnal Antropologi Indonesia secara khusus mengangkat tentang keberadaan etnik tionghoa di Indonesia (No.71/2003). Demikian pula Majalah Intisari dalam edisi khususnya juga mengangkan tentang etnik Tionghoa di Indonesia (2006). Kajian tentang etnis Tionghoa di Bali baru dilakukan oleh Nyoman Griya (1995), yang mengkaji tentang Amalgamasi antara Etnis Cina dengan Etnis Bali. Made Pageh (1998) mengkaji tentang "Peranan Syahbandar Cina di Pantai Utara Bali Pertengahan abad XIX dan awal abad XX. Mudana (2000), mengkaji tentang Etnis Tionghoa di Desa Catur - Kintamani - Bali. Kajian-kajian tersebut di atas belum ada secara khusus mengkaji tentang Modal Sosial. Sehubungan dengan hal itu maka kajian ini difokuskan mengkaji tentang Modal Sosial dalam Pengintegrasian Etnik Tionghoa pada Masyarakat Desa Pakraman di Bali.

Konsep modal sosial pertama kali diperkenalkan oleh L.J. Hanifan pada awal abad ke-20. Hanifan menyatakan bahwa modal sosial bukanlah modal dalam arti biasa seperti harta kekayaan atau uang, tetapi lebih mengandung arti kiasan, namun merupakan asset atau modal nyata yang penting dalam hidup bermasyarakat. Di dalamnya terkandung kemauan baik, rasa bersahabat, saling simpati, serta hubungan sosial dan kerjasama yang erat antara individu dan keluarga yang membentuk suatu kelompok sosial (Atmadja, 2006). Selanjutnya konsep tersebut dikembangkan oleh Piere Bourdieu, Robert Putman, James Colemen, dan Francis Fukuyama. Coleman (1988) mendefenisikan sebagai aspekaspek dari struktur hubungan antar individu yang memungkinkan mereka menciptakan nilai-nilai baru. Modal sosial tersebut mengacu pada aspek-aspek utama dari organisasi sosial, seperti kepercayaan, norma-norma, dan jaringan-jaringan yang dapat meningkatkan efesiensi dalam masyarakat melalui fasilitas bagi tindakantindakan yang terkoordinasi. Elemen pokok modal sosial meliputi: (1) saling percaya, (2) kejujuran, (3) pranata yang meliputi nilai-nilai yang dimiliki bersama, norma-norma dan sanksi-sanksi. Elemen-elemen tersebut dalam dinamikanya harus dikreasikan dan ditramsmisikan melalui mekanismemekanisme sosialbudaya di dalam sebuah unit sosial seperti keluarga, komunitas, asosiasi sukarela, negara dan sebagainya. Hal-hal tersebut juga akan terwadahi dalam beberapa modal sosial yang bersifat horizontal, seperti Paguyuban, Asosiasi, Organisasi Lokal, Jaringan Sosial, dan dilandasi dengan norma dan nilai yang mengacu pada solidaritas, toleransi, 
kepercayaan, dan kerjasama.(Eko, 2004, lihat pula Fukuyama, 2005; Hasbullah, 2006; Hermawanti, dan Hesti Rinandari, 2003).

Fukuyama menyatakan bahwa modal sosial merupakan seperangkat nilai atau norma informal yang dimiliki bersama oleh anggota suatu kelompok yang memungkinkan kerja sama diantara mereka (2005; Hermawanti dan Rinandari, 2003). Konsep-konsep tersebut menunjukkan pengakuan peran penting organisasiorganisasi informal, nilai-nilai budaya, dan keyakinan agama masyarakat setempat. Modal sosial sangat penting untuk mewujudkan integrasi, kemakmuran dan kesejahtraan suatu masyarakat. Setiap modal sosial akan selalu terkandung adanya dua dimensi yang saling terkait yaitu dimensi kognetif/kultural yang berkaitan dengan nilai-nilai, sikap dan keyakinan yang mempengaruhi kepercayaan, solidaritas, dan resiprositas yang mendorong ke arah terciptanya kerjasama dalam masyarakat guna mencapai tujuan bersama. Dimensi kedua adalah dimensi struktural yang berupa susunan ruang lingkup organisasi dan lembaga-lembaga masyarakat pada tingkat lokal, yang mewadahi dan mendorong terjadinya kegiatan-kegiatan kolektif yang bermanfaat bagi seluruh warga masyarakat. Kedua dimensi ini dalam masyarakat selalu berdinamika. Dinamika dari kedua dimensi ini akan memungkinkan terjadinya keharmonisan, dan juga dominasi, hegemoni, jaringan kuasa.

Berdasarkan hal tersebut di atas maka dapat dirumuskan permasalahan penelitian ini sebagai berikut:

1. Bagaimana pola pemukiman etnik Tionghoa pada Desa Pakraman di Bali?
2. Bagaimana jaringan hubungan sosial masyarakat etnik Tionghoa pada Desa Pakraman di Bali?

3. Bagaimana bentuk-bentuk integrasi etnik Tionghoa dengan etnik Bali pada Desa Pakraman di Bali?

4. Bagaimana model kontrol sosial yang dikembangkan oleh masyarakat etnik Tionghoa dan etnik Bali pada Desa Pakraman dalam pemertahanan modal social dan integrasi antar etnik desa Pakraman di Bali?

\section{METODE}

Penelitian ini dilakukan di tiga lokasi masyarakat desa pakraman, yaitu Desa Pakraman Buleleng, Catur, dan Pempatan. Dalam pengkajian penelitian ini menggunakan pendekatan kualitatif. Adapun informan penelitian ini ditentukan secara purposive snowball. Pengumpulan data dilakukan dengan wawancara, observasi, dan studi pustaka. Data yang terkumpul selanjutnya dianalisis dengan teknik triangulasi data dan disajikan secara deskreptif kualitatif.

\section{PEMBAHASAN}

Desa Pakraman di Bali merupakan satu kesatuan sosial religius. Sebagai sebuah desa pakraman, desa ini dipimpin oleh Kelian Desa Pakraman. Setiap desa pakraman memiliki wewidangan/ pelemahan dan warga masyarakat/pawongan. Keberadaannya sebagai satu kesatuan sosial religius sangat penting artinya bagi masyarakat di Bali, baik dalam kaitannya dengan pengembangan jaringan sosial, pembinaan dan pengerahan sumber daya manusia serta dalam aktivitas keagamaan yang terkait dengan pelaksanaan Panca Yadnya. 
Dari perspektif sosiokultural masyarakat desa pakraman Buleleng, Catur dan Pempatan bersifat multietnik. Kemultietnikannya dapat dilihat dari adanya berbagai etnik yang ada di daerah tersebut, di desa pakraman Buleleng tinggal etnis Tionghoa, Arab, Sasak, Madura, Padang, Bugis, Timor, dan lain sebagainya. Di Desa Catur terdapat etnis Tionghoa. Di desa Pempatan pupuan terdapat etnis Tionghoa, dan Madura. Keberadaan kemultietnikan dan kemultikulturan dari masyarakat desa pakraman di Bali terpresentasikan juga dari adanya perkampungan yang berlatar belakang etnik, seperti Banjar Bali, Banjar Jawa, Kampung Bugis, Kampung Muslim, Kampung Sasak, Kampung Arab. Adanya perkampungan semacam itu dilatar belakangi oleh proses migrasi dan pemertahanan identitas etnik serta pengembangan rasa aman di daerah rantau yang multietnik. Pengembangan dan pemertahanan identitas etnik juga dipresentasikan dengan munculnya berbagai kelompok berlatar belakang etnik, seperti Kelompok Suka Duka Keluarga Besar Masyarakat Sasak, Kelompok Suka Duka Keluarga Besar Masyarakat Bugis, Kelompok Suka Duka Masyarakat Cina, Kelompok Suka Duka Masyarakat Sumba, Kelompok Suka Duka Masyarakat Padang, dsb. Bahkan dikalangan mahasiswapun hal seperti itu juga berkembang, ini dapat dilihat dari munculnya kelompok mahasiswa yang berlatar belakang kedaerahan, seperti Kelompok Mahasiswa Lombok. Kemulti etnikannya masyarakat juga tampak dari adanya sarana publik seperti pemakaman Cina/Kuburan Cina.

Kemultikulturan suatu masyarakat juga dapat dilihat dari adanya berbagai kelompok keagamaan, di Desa Pakraman di Bali ada berbagai kelompok keagamaan seperti: Hindu, Islam, Katolik, Protestan, Budha, dan Kong Hu-Tsu. Keberadaan masing-masing kelompok keagamaan tersebut memiliki tempat ibadah, seperti Pura bagi umat Hindu, Masjid bagi umat Islam, Gereja bagi umat Kristen dan Protestan, Wihara bagi umat Budha. Identitas kemultikulturan juga dapat dilihat dari adanya kelembagaan-kelembagaan yang berbasis keagamaan, seperti PHDI bagi umat Hindu, kelompok pengajian bagi umat Islam, Tempat Pembinaan Umat bagi Kristen dan Protestan. Presentasi dari kemultikulturan juga dapat disimak dari adanya ruang publik yang berlatar belakang etnik, seperti Kuburan (Kuburan Kristen, Kuburan Cina, Kuburan Muslim, Kuburan Hindu), Pendidikan (PGA, STKIP Agama Hindu, Muhamadiyah, SMU Swastiastu/Kristen, Kursus Bahasa Mandarin, Kursus Bahasa Arab, dll). Presentasi kemultietnikan/kemultikulturan dari masyarakat Desa Pakraman di Bali juga dapat dilihat dari adanya pelayanan publik yang berbasis etnik/ikatan primordial seperti Warung Muslim, Budha ha-ha, Bakso Bali, Rumah Makan Padang, Bakso Solo, Warung Sate Madura, Warung Jawa, dll. Kemultikulturan juga dapat dilihat dari pakaian yang dipergunakan dan aktivitasaktivitas sosial yang berbasis ikatan primordial, seperti Bahasa pergaulan, nama panggilan dalam pergaulan, dll. Kondisi kemajemukakan masyarakat desa pakraman akan semakin bervariasi bila dilihat secara vertical maupun secara horizontal (Nasikun, 1987). Secara Horizontal masyarakat desa tidak hanya menampakkan adanya variasi etnik, tetapi juga akan menampakkan adanya varisasi agama, klan/wangsa, orientasi politik, pekerjaan. Sedangkan secara vertikal akan

Jurnal IImu Sosial dan Humaniora | 34 
menampakan berbagai variasi jenjang kehidupan dalam berbagai dimensinya, baik dari dimensi ekonomi, pendidikan, dan kekuasaan. Masing-masing kelompok tersebut tentu saja akan menampilkan pola budaya, identitas, jaringan sosial, dan perilaku sosial yang berbeda antara satu kelompokdengan kelompok yang lain. Dalam kontek rwa bhinenda atau oposisi binary, kondisi kemultietnikan/ kemultikulturan masyarakat desa pakraman di Bali di satu pihak dapat menjadi kebanggaan, merupakan modal sosial/budaya, namun di sisi yang lain juga merupakan sumber kerawanan sosial. Sehubungan dengan hal itulah maka diperlukan upaya penggalian sumbersumber pengintegrasi masyarakat baik melalui pengungkapan pengakuan akan kebinnekaan maupun keikaan/ pluralisme dan universalisme, dialog antar kelompok etnis.

Keberadaan masyarakat multietnik tentu juga nampak dari adanya masyarakat yang bermukim di desa pakraman di Bali. Pola pemukiman masyarakat etnik Tionghoa umumnya berbaur terutama disekitar pusatpusat aktivitas ekonomi, sebagaimana tampak pada pola pemukiman etnik Tionghoa di Desa pakraman Buleleng, Catur, dan Pempatan. Kenyataan itu memungkinkan terjadinya hubungan sosial yang semakin intensif. Hal ini diperkuat dengan berbagai ritual sosial tegur sapa atau saling tolong menolong pada berbagai kegiatan suka duka. Kondisi semacam itu tidak saja dapat memperkuat integrasi tetapi juga dapat mengembangankan modal sosial baik dalam bentuk hubungan pertetanggaan, suka duka, gotong royong, maupun dalam bentuk jaringan sosial lainnya. Pola pemukiman sebagai arena sosial sebagaimana dikonsepsikan oleh
Pierre Bourdieu (Rindawati, 2010) pada desa pakraman dapat menjadi ruang bagi proses dialog atau tindakan komunikatif sebagaimana dikemukakan oleh Jurgen Habermas (Habermas, 2006) dan ruang konstruksi sosial sebagaimana dikonsepsikan oleh Peter $\mathrm{L}$ Berger dan Thomas Lukman (Sriningsih, 2010) dalam penguatan modal sosial dan integrasi.

Dalam masyarakat multikultural di Bali dialog antara kelompok etnik pada umumnya mempergunakan bahasa Indonesia. Penggunaan bahasa Indonesia dalam dialog antar anggota masyarakat tentu saja akan dapat mengurangi terjadinya mis konsepsi dan memudahkan adanya kesatuan pemahaman tentang berbagai permasalahan sosial yang dihadapinya. Namun dalam hal-hal tertentu juga diselingi dengan penggunaan bahasa etnik, seperti Bahasa Bali, Bahasa Jawa, dan Bahasa Cina. bahkan pada desa pakraman seperti di Desa Catur dan Pempatan hubungan sosialnya cendrung menggunakan bahasa Bali. Dengan demikian pola pemukiman yang dikembangkan oleh masyarakat Tionghoa pada desa pakraman tidak saja berkontribusi pada kehidupan ekonomi tetapi juga kehidupan sosial/ modal sosial. Jaringan sosial yang dikembangkan dalam kehidupan di wilayah pemukiman pada awalnya berupa jaringan hubungan sosial yang didasarkan atas kedekatan tempat tinggal. Hal ini dilandasi dengan pemikiran bahwa tetangga merupakan teman yang paling dekat dalam mengatasi masalah suka dan duka. Jaringan hubungan sosial yang juga dikembangkan adalah jaringan hubungan sosial yang di dasarkan atas kekerabatan antar etnik Tionghoa dengan etnik Bali. Jaringan hubungan sosial yang lain adalah yang didasarkan atas identitas etnik, hal ini dapat dilihat dari 
adanya perkumpulan suka duka etnis Tionghoa Ling San Ting/Bukit Suci. Jaringan sosial antar etnis sangat nampak peranannya dalam kegiatan suka duka, sebagaimana terlihat pada masyarakat Desa Catur. Setiap ada warga desa Catur yang meninggal baik etnis Bali maupun etnis Tionghoa setiap warga wajib menyumbang bahan-bahan upakara dan uang sebesar Rp. 1000, -.

Di samping itu ada juga jaringan sosial yang didasarkan atas kepentingan anggota masyarakat seperti dengan pengembangan perkumpulan olah raga sebagai suatu arena sosial. Arena sosial semacam ini sangat penting artinya dalam pengembangan jaringan hubungan sosial, misalnya di Klenteng Ling Gwan Kiong setiap hari sabtu dan minggu diadakan latihan bersama Barong Sai yang diikuti oleh anak-anak anggota masyarakat etnis Tionghoa dan anggota etnis Bali. Hal yang sama juga dapat dilihat pada kegiatan olah raga senam Taichi. Latihan ini diikuti oleh anggota masyarakat dari berbagai etnis, termasuk juga etnis Bali dan etnis Tionghoa. Kegiatan latihan dilakukan di Pabean dan di pantai penimbangan di Rangon Sangset (Rumah Makan milik etnis Bali). Pengembangan jaringan sosial juga dilakukan melalui aktivitas keagamaan, seperti dalam setiap piodalan di Pura Segara, Pura Desa, Pura Dalem, dan Pura Jagat Natha, mereka selalu datang melaksanakan persembahyangan dan mengaturkan dana punia baik berupa uang maupun barang. Pengembangan jaringan sosial juga dilakukan melalui pelayanan sosial kesehatan, seperti yang dilakukan oleh Cik Ha Myo dan Jro Era yang samasama menekuni perdukunan/tukang pijat. Mereka mengembangan hubungan sosial melalui layanan jasa perdukunan/pemijatan.
Kondusifnya masyarakat multikultur di Bali juga dapat dilihat dari adanya kerjasama antar etnik dalam berbagai ruang publik, seperti misalnya di Pasar Anyar I/II, Pasar Buleleng, Pasar Banyuasri, dan Pasar Pupuan. Dalam aktivitas pasar mereka menampakkan hubungan yang harmonis. Hal ini tampak dari adanya kesediaan dari pedagang kelompok etnik tertentu kepada kelompok etnik lainnya memberikan peminjaman tempat, alat, barang, dan bahkan uang, disamping bantuan tenaga. Mantapnya hubungan tersebut juga diperkuat oleh adanya layanan-layanan publik yang terbuka bagi berbagai macam etnik, seperti yang dilakukan oleh dilakukan oleh Cik A Mio, dan Jro Era (Cina/Budhis), atau sebagaimana yang dilakukan oleh almarhum Pak Ketut Wijana (Bali/Hindu). Mereka ini memberikan pelayanan dengan keterbukaan, ketulusan dan penuh kasih. Monumen kemantapan hubungan antar etnik/sub kultur juga dapat dilihat dari adanya keterbukaan kelembagaan umat untuk saling mengakui, saling menyadari, dan saling menerima. Hal ini dapat dilihat dari keterbukaan Pura Taman Sari bagi setiap umat beragama, pura ini terbangun dari sumbangan berbagai umat baik yang beragama Hindu, Budha, Kristen, Islam dan Kong Hu-Tsu. Keterbukaan semacam ini juga tampak pada Klenteng di Pabean. Tempat ini dijadikan simpul hubungan antar umat beragama, karena tempat suci ini terbuka bagi masyarakat umum untuk berkunjung, menanyakan nasib, keberuntungan, dan kesehatan.

Pada masyarakat Desa Pakraman di Bali dikembangkan berbagai kearifan sosial yang dapat menjadi perekat sosial dalam masyarakat multikultur. Dalam tataran teks kognitif terdapat ungkapan kearifan sosial seperti celebingkah batan biu, gumi 
linggah ajak liu (Bumi ini luas dan ditempati banyak orang), dos sente don pelendo, ade kene ade keto (ada yang begini ada yang begitu/penghargaan terhadap variasi sosial). Teks ini mengakui adanya perbedaan karakter dari anggota masyarakat. Hal ini seljalan dengan ungkapan buka nyuhe aijeng (seperti kelapa satu tangkai tidak ada yang sama). Adanya perbedaan antar anggota masyarakat juga diakui dalam awigawig desa pakraman dengan memposisikan krama desa menjadi krama negak dan krama tamiu (anggota masyarakat yang berkedudukan sebagai anggota desa pakraman, dan angggota masyarakat yang berkedudukan sebagai tamu). Teks kognitif yang lain adalah adanya ungkapan menyamal bersaudara seperti: nyama Madura, nyama Jawa, nyama Sasak, nyama Arab, nyama Cina, dll. Ungkapan-ungkapan semacam itu juga berkembang pada masyarakat etnik Tionghoa, bahkan ada ungkapan yang menyatakan bahwa etnik Tionghoa merupakan kakak dari etnik Bali. Pernyataan kakak dan adik dalam hubungan antar etnik menyiratkan akan adanya hubungan persaudaraan/ geneologis diantara kedua etnik.

Bentuk integrasi antara etnis Tionghoa dan etnis Bali yang sangat penting artinya adalah perkawinan. Kelembagaan perkawinan tidak saja mengintegrasikan antara dua insan yang saling mencintai/ suami dan istri tetapi juga mengintegrasikan antar kerabat suami dan kerabat istri, seperti yang dialami oleh Dewa Aji Mangku Suwija (55), Sukasna Pandit (40), Pun Bun Siok (58), Tiong Kok Yen (62). Hal seperti itu juga terjadi di desa lainnya di Bali. Hal itu dibenarkan oleh I Nengah Bumbung, seperti misalnya perkawinan Nengah Wirya Kusuma (60) denga Dina Wati (55), I Gusti Putu Eka (50) menikah dengan Roosmini (40) mereka merasakan jaringan sosial mereka semakin luas. Bentuk integrasi yang lainnya adalah dalam bentuk ikatan persekutuan/organisasi/ perkumpulan antar etnis misalnya dalam kaitannya dengan aktivitas sosial seperti Suka Duka, perkumpulan Olah Raga Taichi, Ling Tien Kung, Tenis, Bayu Pertiwi, dan lain sebagainya. Dalam bidang budaya misalnya sebagai anggota Perkumpulan Barong Sai. Simpul-simpul sosial seperti itu berkontribusi dalam penguatan integrasi sosial lintas etnis pada masyarakat multikultur. Penguatan integrasi antar etnis Bali dengan etnis Tionghoa juga dikontribusi oleh adanya mitos hubungan geneologis dan kultural. Hal itu misalnya dapat disimak dari ceritra hubungan antara etnis Bali dengan etnis Tionghoa bagaikan hubungan dua saudara sekandung, kakak ber adik.

Dalam rangka mempertahankan integrasi antar etnik Tionghoa dan etnik Bali, masyarakat mengembangkan suatu sistem pengendalian sosial. Pengendalian sosial pada dasarnya menghubungkan penyimpangan dengan lemahnya ikatan terhadap lembaga-lembaga dasar masyarakat, keluarga, agama, sekolah dan peradilan. Secara umum dapat dinyatakan bahwa masyarakat Bali mengembangkan sistem pengendalian sosial yang bersifat sekala dan niskala. Proses pengendalian sosial dalam masyarakat Bali bisa berasal dari bawah dan dari atas (Keesing, 1992; Scott, 1993).

Sarana pengendalian sosial yang diterapkan oleh suatu organisasi, menurut Etzioni (1985) dapat diklasifikasikan ke dalam tiga kategori analitik, yaitu: fisik, material, atau simbolik. Untuk memantapkan proses pengendalian sosial mereka juga mengembangkan berbagai aturan normatif 
sebagaimana tertuang dalam setiap AwigAwig Desa Pakraman di Bali. Kratz (1974: 74) menyatakan bahwa pengendalian sosial pada dasarnya merupakan suatu cara dengan mana suatu kelompok, golongan atau lapisan masyarakat tertentu melaksanakan keseimbangan atau merubah struktur nilai-nilai politik, kebudayaan, agama dan adat sopan santun. Sehubungan dengan hal itu maka bagi masyarakat Hindu Bali yang membimbing dan mengarahkan prilakunya adalah nilai-nilai yang tertuang dalam ajaran Agama Hindu, seperti: Tat Twam Asi, Tri Kaya Parisudha, Karma Pala, Yajna, Guru Bhakti, dan lain sebagainya. Hal-hal seperti itu dijadikan dasar dalam proses pengendalian sosial pada masyarakat desa Pakraman di Bali, dalam menjaga modal sosial dan integrasui antar etnik. Tat Twam Asi merupakan pencerminan cinta kasih universal antara sesama. Cita kasih merupakan landasan utama bagi berkembangnya toleransi, rasa persaudaraan dan kerukunan hidup antar sesama manusia. Hal itu juga diperkuat oleh berbagai nilai tata susila Hindu, seperti tresna asih, anresangsia, catur paramita, tri kaya pariudha, dan yadnya. Nilai-nilai tersebut tentu akan dapat mengendalikan prilaku sosial dari anggota masyarakat Bali, lebih-lebih dengan adanya keyakinan terhadap hukum karma phala. Sehingga tidak terjadi perlakuan-perlakuan yang kurang terpuji terhadap orang lain. Pengendalian sikap dan prilaku yang kurang terpuji dan pengembangan sikap welas asih dan tresna bhakti akan dapat menjadi kekuatan bagi kerukunan antar sesama umat manusia. Hal itu lebih lanjut menjadi penguat dalam dinamika sistem sosial masyarakat Bali.

Sistem sosial terkecil dalam masyarakat desa pakraman di Bali adalah kurenkeluarga inti. Kuren memainkan peranan yang penting dalam proses pengendalian sosial. Di dalam kuren inilah mulai dikonstruksikan nilai-nilai adiluhung oleh setiap anggota keluarga. Sistem sosial yang lebih besar dari keluarga adalah dadia. Dadia pada masyarakat Bali pada dasarnya merupakan kumpulan beberapa kuren/ keluarga inti dari garis keturunan kepurusal garis keturunan dari pihak laki-laki. Masyarakat Bali di samping terikat dalam kesatuan keluarga dan dadia juga terikat dalam kesatuan tempat tinggal bersama, kesatuan administrasi dan seka (Geertz, 1979). Acuan dalam berperilaku berupa gagasan, dan nilai-nilai yang terumuskan dalam sistem budaya masyarakat Bali misalnya dalam susastra Hindu, awig-awig desa pakraman, ungkapan-ungkapan dan hukum formal lainnya. Dinamika sistem nilai budaya Bali mengacu pada konsepsi Desa, Kala, Patra dan Dharma, Artha, Kama.

$$
\text { Dalam dinamika sistem }
$$

pengendalian sosial, masyarakat Bali menggunakan berbagai teknologi, baik teknologi tradisional maupun teknologi modern (Foucault, 1997). Pandangan semacam ini sejalan dengan perspektif materialis, yang memandang bahwa teknologi memberikan sumbangan yang besar bukan saja dalam proses produksi, tetapi juga dalam proses perubahan sosial budaya dan sekaligus kontrol sosial. Hal seperti ini juga dilakukan pada desa pakraman di Bali misalnya melalui penggunaan pengeras suara, kulkulkentongan, dll. Di samping itu dalam masyarakat Bali juga menggunakan bahasa dalam proses pengendalian sosial. Hal ini dapat disimak dari adanya kebiasaan menggunakan sindiran, ungkapan-ungkapan (sesenggakan, wangsalan, bladbadan) seperti Yen Ngae Baju Sikutang di Deweke 
(kalau buat pakaian ukur pada diri sendiri, artinya kalau melakukan perbuatan tertentu kembalikan pada diri sendiri), gunjingan dan tidak bicara dalam masa waktu tertentu/ puik, dalam proses pengendalian sosial. Dengan demikian secara singkat dapat dikatakan masyarakat desa pakraman di Bali dalam proses pengendalian sosial untuk mempertahankan modal sosial dan integrasi antar etnik menggunakan pendekatan sekala dan niskala.

\section{SIMPULAN}

Berdasarkan uraian tersebut di atas maka dapat disimpulkan sebagai berikut:

1. Desa Pakraman di Bali merupakan masyarakat multietnis, kemultietnikan tersebut dapat dilihat dari adanya berbagai kelompok etnik yang bermukim di wilayah tersebut, seperti etnis Bali, Etnis Tionghoa, Etnis Jawa, Etnis Madura, dll.

2. Pola pemukiman etnis Tionghoa pada umumnya berbaur dan dekat dengan pusat aktivitas ekonomi.

3. Jaringan hubungan sosial yang dikembangkan ada yang didasarkan atas kedekatan tempat tinggal, kekerabatan, kepentingan sosial, ekonomi, budaya dan politik.

4. Bentuk integrasi sosialnya dalam bentuk perkawinan, hubungan pertetanggaan, hubungan tempat tinggal,

persekutuan/perkumpulan/organisasi sosial baik yang berbasis sosial dan budaya.

5. Model kontrol sosial yang dikembangkan berupa penanaman nilai melalui sosialisasi, pemanfaatan sisitem sosial keluarga/kuren, dadia, desa pakraman, kelembagaan formal lainnya, dan dengan pemanfaatan budaya fisik seperti Kulkul/ kentongan, pengeras suara, dll. Di samping itu juga dengan menggunakan bahasa. Dengan kata lain kontrol sosila dalam pemeliharaan modal sosial dan integrasi antar etnik dilakukan secara sekala dan niskala.

\section{SARAN-SARAN}

1. Kondisi kemultietnikan masyarakat memerlukan kebijaksanaan pemerintah secara optimal dalam pemeliharaan kondisi yang kondusif sehingga menjadi kekuatan positif dalam berbagai dinamika kehidupan masyarakat.

2. Pola pemukiman yang berbaur sangat rentan bagi terjadinya konflik. Untuk itu upaya pengembangan keterbukaan/ dialog yang berkeadilan dan berkesinambungan perlu terus diupayakan.

3. 3.Kesadaran dan partisipasi masyarakat multietnik dalam mengembangankan jaringan sosial perlu terus dikembangkan melalui kebijakan pemerintah dan sosialisasi pada masyarakat.

4. Berbagai bentuk integrasi antar etnik Bali dengan etnik Tionghoa perlu terus dikembangkan baik melalui kebijakan pemerintah, maupun melalui penelitian dan pengabdian masyarakat dari kelembagaan perguruan tinggi

5. 4 Berbagai model kontrol sosial dalam mempertahankan modal sosial dan integrasi antar etnik Bali dengan etnik tionghoa dapat dijadikan sebagai suatu inspirasi dalam mengatasi permasalahan yang berkembang pada masyarakat multietnik. 
6. Tentu saja harus diikuti adanya berbagai keterbatasan dalam kajian ini sehingga diperlukan adanya upaya yang maksimal untuk melakukan kajian-kajian yang lebih mendalam tentang masyarakat multietnik, penguatan modal sosial untuk mengatasi berbagai kerapuhan masyarakat bangsa yang multietnik.

\section{DAFTAR RUJUKAN}

Agung, Ide Anak Agung Gde, 1989. Bali Pada Abad XIX, Yogyakarta: UGM Pres.

Ardika, I Wayan, 1989. "Bali dalam Sentuhan Budaya Global Pada Awal Abad masehi" dalam Dinamika Kebudayaan Bali.

I Wayan Ardika dan I Made Sutaba (ed). Denpasar: Upanisad.

Atmadja, Nengah Bawa, 1997. Pendidikan Manusia Antarbudaya, Bali Post 11 April 1997.

2006, Bali Pada Era Globalisasi, Singaraja: IKIP N Singaraja

Badaruddin, 2005, Modal Sosial (Sosial Capital) dan Pemberdayaan Komunitas Nelayan, dalam Isu-isu Kelautan Dari Kemiskinan Hingga Bajak Laut, Yogyakarta: Pustaka Pelajar.

Burhanuddin, 1988. "Ace dan Baba, dalam Stereotip Etnik, Asimilasi, Integrasi Sosial, Jakarta: Grafika Kita.

Eko, Sutoro, 2004, Modal Sosial, Desentralisasi dan Demokrasi Lokal, dalam Jurnal Analisis CSIS, Vol.33, No.3, Sept 2004, Jakarta: CSIS

Foucault, Michel, 1997, Disiplin Tubuh, Bengkel Individu Moder, Yogyakarta: LKiS.

Geertz, C, 2000. Negara Teater. Yogyakarta: Bentang

Griya, Nyoman, 1995. Amalgamasi Etnik Tionghoa di Singaraja, Skrepsi (S1). FKIP-UNUD: Denpasar.
Hardiman, Francisco, 1990. Kritik Ideologi Pertautan pengetahuan dan Kepentingan, Yogyakarta: Kanisius

Hasbullah, Jousairi, 2006, Sosial Capital, Menuju Keunggulan Budaya Manusia Indonesia, Jakarta: MR-United Press.

Hendarti, Paulina Ratna, 1975. Perbedaan Orientasi Nilai Budaya Antara Generasi Muda dan Orang Tua Golongan Keturunan Cina. Jakarta: Leknas.

Hermawanti dan Hesti Rinandari, 2002, Penguatan dan Pengembangan Modal Sosial Masyarakat Ada, dalam Copyright @ 2003 Institute For Research and Empowerment.

Kartodirdjo, Sartono, 1975. Sejarah nasional, Jakarta: Depdikbud.

Koentjaraningrat, 1982, Masalah-Masalah pembangunan Bunga Rapai Antropologi Terapan. Jakarta: LP3ES.

Kratz, Ulrich, 1974. Bahasa, Komunikasi, dan Kontrol Sosial, dalam Prisma 6/1974.Jakarta: LP3ES

Mudana, I Wayan, .2000. Integrasi Etnik Tionghoa Pada Masyarakat Desa Adat di bali Kasus Catur-KintamaniBali. Singaraja: STKIP.

Onghokham, 1983. Rakyat dan Negara. Jakarta: Sinar Harapan 1991. Minoritas Cina dan Globalisasi. dalam Tempo No.26/8/1991.

Pageh, Made, 1998. Peranan Syahbandar Cina di pantai Utara Bali Pertengahan Abad XIX dan Awal Abad XX, Makalah S2 Sejarah. Yogyakarta: UGM Press. 



\title{
IDENTIFIKASI DAN ANALISIS JENIS KUASA, GAYA KEPEMIMPINAN, DAN IMPLEMENTASI PENDEKATAN SUPERVISI AKADEMIK PARA KEPALA SEKOLAH SMAN SEBAGAI FAKTOR DETERMINAN DALAM RANGKA PENINGKATAN KUALITAS KOMPETENSI PROFESIONALISME GURU (Studi Tentang Persepsi para Guru SMAN di Kabupaten Buleleng)
}

\author{
I Nyoman Natajaya ${ }^{1}$, Gde Anggan Suhandana ${ }^{2}$ \\ 1Jurusan PPKn, Fakultas IImu Sosial, Universitas Pendidikan Ganesha, \\ Singaraja, Indonesia \\ 2Jurusan Teknologi Pendidikan, Fakultas IImu Pendidikan, \\ Universitas Pendidikan Ganesha, Singaraja, Indonesia
}

\begin{abstract}
Abstrak
Penelitian ini menggunakan rancangan deskriptif korelasional dan bersifat ex post facto. Tujuan penelitian ini adalah untuk mengetahui: (a) seberapa besar determinan dari faktor jenis kuasa kepala sekolah terhadap kualitas kompetensi profesionalisme guru, (b) seberapa besar determinan dari faktor gaya kepemimpinan kepala sekolah terhadap kualitas kompetensi profesionalisme guru, (c) seberapa besar determinan dari faktor pendekatan supervisi akademik kepala sekolah terhadap kualitas kompetensi profesionalisme guru, dan (d) seberapa besar determinan secara bersama-sama dari faktor jenis kuasa, gaya kepemim-pinan, dan pendekatan supervisi akademik kepala sekolah terhadap kualitas kompetensi profesiolisme guru SMA.N di Kabupaten Buleleng. Populasi penelitiannya sebanyak 567 orang guru yang mengajar pada 12 SMA, dan sampelnya ditetapkan secara proporsional random sampling sebanyak 114 atau sekitar $20 \%$. Pengumpulan data dengan kuesioner yang telah teruji validitas dan reliabilitasnya, kemudian wawancara mendalam, dan diskusi. Analisis data deskriptif menemukan bahwa kualitas kompetensi profesional guru dapat dikategorikan tinggi, jenis kuasa kepemimpinan kepala sekolah dapat dikategorikan baik, gaya kepemimpinan kepala sekolah dapat dikategorikan baik, dan implementasi pendekatan supervisi kepala sekolah dapat dikegorikan baik. Hasil uji statistik terhadap hipotesis dengan menggunakan rumus regresi ganda menemukan bahwa terdapat determinanasi variabel jenis kuasa kepala sekolah terhadap kualitas kompetensi profesional guru sebesar 5, 3\%, terdapat determinasi variabel gaya kepemimpinan kepala sekolah terhadap kualitas kompetensi profesional guru sebesar $10.7 \%$, terdapat determinasi pendekatan supervisi akademik kepala sekolah terhadap kualitas kompetensi profesional guru sebesar 7,6\%, dan terdapat determinasai secara bersama-sama variabel jenis kuasa kepala sekolah, gaya kepemimpinan kepala sekolah, dan pendekatan supervisi akademik kepala sekolah terhadap kualitas kompetensi profesionalisme para guru sebesar $14,0 \%$.
\end{abstract}

Kata kunci: Jenis kuasa, Gaya kepememimpinan, supervisi Akademik, Kepala sekolah, Kompetensi guru 


\begin{abstract}
This study used dercriptive correlation design and ex post facto. The study aimed to investigate: (a) the determinant of principal's authority factor toward the quality of teacher professionalism competence, (b) the determinant of the principal's leadership style factor on the quality of teacher professionalism competence, (c) the determinant of academic supervision approach of the principal's toward the quality of teacher professionalism competence, (d) the determinant of all factors; authority factor, leadership style factor, and academic supervision approach of the principal's toward the quality of professionalism competence of state senior high school teacher in Buleleng Regency. The population of this study was 567 teachers of senior high school of 12 schools. The samples were 114 teacher or about $20 \%$ which determined proportionally by using ramdom sampling. The data were obtained by using questionnaire, depth interview and discussion. Descriptive analysis found that of teacher professionalism competence can be categorized high, authority leadership of principal can be categorized good, leadership style can be categorized good, and the implementation of principal academic supervision approach can be categorized good. Multiple regression formula was used to test the hypothesis. The results showed that there was significant determination of variable principal's authority on the quality of teacher professionalism competence $(5,3 \%)$, there was significant determination of variable principal's leadership style factor on the quality of teacher professionalism competence $(10,7 \%)$, there was significant determination of variable principal academic supervision approach on the the quality of teacher professionalism competence (7,6\%), and there was significant determination of all variables; principal's authority, principal's leadership style, and academic supervision approach of principal on the quality of teachers professionalism competence $(14,0 \%)$
\end{abstract}

Keywords: Authority, Leadership Style, Academic Supervision, Principal, Teacher Competence.

\section{PENDAHULUAN}

Pada saat ini kualitas kompetensi profesionalisme guru di Kabupaten Buleleng cenderung masih rendah. Indikasi yang menunjukkan endahnya kualitas kompetensi pro-fesionalisme guru tersebut adalah temuan pe-nelitian Natajaya (2008) yang menyimpulkan bahwa pemahaman secara konsepsional para guru SMA.N di Kota Singaraja tentang model-model manajemen pembelajaran dapat dikategorikan cenderung relatif kurang. Te-muan penelitian Natajaya yang (2008) menyimpulkan bahwa para guru SMA.N Di Provinsi Bali memiliki pemahaman secara konsepsional tentang manajemen pembelajar-an dan asesmen inovatif dapat dikategorikan relatif kurang. Kemudian penelitian Natajaya (2009) temuannya menyimpulkan bahwa para guru SMA.N Di Provinsi Bali memiliki pemahaman tentang manajemen pembelajar-an relatif cukup. Temuan yang lainnya adalah untuk kelompok guru bidang studi IPA dapat dikategorikan memiliki pemahaman tentang manajemen pembelajaran relative cukup, ke-lompok guru bidang studi IPS dan bahasa dapat dikategorikan relatif kurang. Kemudian temuan yang lainnya disimpulkan (1) pema-haman secara konsepsional para kepala SMA. N di Provinsi Bali tentang supervisi penga-jaran dapat dikategorikan masih relatif cukup, (2) pemahaman secara konsepsional para kepala sekolah SMA.N di Provinsi Bali ten-tang manajemen pembelajaran dapat dika-tegorikan masih relatif kurang, (3) semua kepala sekolah SMA.N di provinsi Bali me-nyatakan bahwa 
dalam melakukan pembi-naan terhadap para guru di lapangan telah menerapkan model pendekatan supervisi pengajaran direktif, kolaboratif, dan non-direktif, serta dalam menerapkannya belum dapat dilakukan secara baik, dan tidak diser-tai dengan dokumen program perencanaan.

Dalam teori manajemen pendidikan disebutkan ada beberapa faktor determinan terhadap kecendrungan rendahnya kualitas kompetensi profesionalisme guru, yaitu jenis dan sumber kuasa kepala sekolah, gaya kepe-mimpinan kepala sekolah, dan impelementasi pendekatan supervisi akademik para Kepala Sekolah.

Berdasarkan pada penomena, dan kajian secara empirik dan teoritik yang telah diuraikan di atas, maka dalam penelitian ini ada beberapa permasalahan yang dijawab, yaitu: (a) seberapa besar determinan dari faktor jenis kuasa kepala sekolah terhadap kualitas kompetensi profesionalisme guru, (b) seberapa besar determinan dari faktor gaya kepemimpinan kepala sekolah sterhadap kua-litas kompetensi profesionalisme guru, (c) seberapa besar determinan dari faktor pende-katan supervisi akademik para kepala sekolah tehadap kualitas kompetensi profesionalisme guru, dan (d) seberapa besar determinan secara bersama-sama dari faktor jenis kuasa, gaya kepemimpinan, dan pendekatan super-visi akademik kepala sekolah terhadap kua-litas kompetensi professionalisme guru SMA. N di Kabupaten Buleleng.

Hasil penelitian ini secara teoritik diharapkan dapat mengkontribusi pengembangan ilmu Manajemen Pendidikan. Sebagai bahan konsumsi bagi staf dosen pada per-guruan tinggi yang mengampu mata kuliah Administrasi Pendidikan, Manajemen Pendi-dikan, dan Kepemimpinan Pendidikan, seba-gai bahan konsumsi dan menambah wawasan bagi para kepala sekolah, dan para pengawas dalam bidang pembelajaran, kepemimpinan, dan kesupervisian.

Secara praktisnya hasil penelitian ini diharapkan sebagai bahan masukkan bagi staf dan pimpinan Kementrian Pendidikan dan Kebudayaan di daerah Kabupaten Buleleng dalam rangka mengambil berbagai kebijakan yang berkaitan dengan sistem pengembangan kompetensi dan profesionalime guru, dan para kepala sekolah.

\section{KAJIAN PUSTAKA}

Cooper (Sudjana. 1989) mengemukakan kompetesi guru mencakup: (1) mempunyai pengetahuan tentang belajar dan ting-kah laku manusia, (2) mempunyai penge-tahuan dan menguasai bidang studi yang dibinanya, (3) mempunyai sikap yang tepat tentang diri sendiri, sekolah, sejawat, bidang studi yang dibina, dan (4) mempunyai kete-rampilan teknik mengajar. Grasser (Sudjana. 1989) menyatakan ada empat kompetensi guru, yaitu: (1) menguasai bahan pelajaran, (2) kemampun mendiagnosis tingkah laku siswa, (3) kemampuan melaksa-nakan proses pengajaran, dan (4) kemampuan mengukur hasil belajar siswa.

Dahulu sekitar tahun 1980 an guru dituntut untuk memiliki 10 kompetensi yang dikenal dengan 10 kompetensi dasar guru yang didalamnya mencakup: (1) menguasai bahan, (2) mengelola program belajar mengajar, (3) mengelola kelas, (4) menguasai me-dia atau sumber belajar, (5) menguasai landa-san kependidikan, (6) mengelola interaksi belajar mengajar, (7) menilai prestasi belajar siswa, (8) mengenal fungsi dan program bim-bingan penuluhan, (9) mengenal dan menye-lenggarakan 
administrasi sekolah, dan (10) memahami prinsip-prinsip dan penafsiran hasil penelitian untuk keperluan pendidikan dan pengajaran (Uno. 2007).

Dalam Undang-undang No. 14 Tahun 2005 tentang Guru dan Dosen menetapkan kompetensi guru sebagai seperangkat pnge-tahuan, keterampilan, dan perilaku yang harus dimiliki, dihayati, dan dikuasai oleh guru dalam melaksanakan tugas keprofe-siannya. Kompetensi guru tersebut menca-kup empat kemampuan, yaitu: kompetensi paedagogik, kompetensi kepribadian, kompe-tensi sosial, dan kompetensi profesional yang diperoleh melalui pendidikan profesi.

Dalam teori manajemen terdapat be-berapa faktor determinan terhadap kualitas kompetensi profesionalisme guru. Faktor ter-sebut adalah jenis kuasa kepala sekolah. Thoha (1990) dengan mengutip pendapat Walter Nord memberikan pengertian kekua-saan sebagai suatu kemampuan untuk mem-pengaruhi aliran energi dan dana yang tersedia untuk mencapai suatu tujuan yang berbeda secara jelas dari tujuan yang lainnya. Wexley dan Yukl (1977) memberikan pe-ngertian kekuasaan sebagai kapasitas mempengaruhi orang lain. Kemudian Rivai (2004) memberikan pengertian kekuasaan sebagai kemampuan untuk membuat orang lain mela-kukan apa yang diinginkan oleh pihak yang lainnya. Rogers (1973) merumuskan kekua-saan sebagai suatu potensi dari suatu pe-ngaruh. Dengan demikian kekuasaan adalah suatu sumber yang bisa atau tidak bisa dipergunakan. Pengunaan kekuasaan menga-kibatkan perubahan dalam seseorang atau kelompok akan mengangkat suatu perubahan perilaku yang diinginkan. Rogers (1973) merumuskan kepemimpinan sebagai proses untuk mempengaruhi aktivitas-aktivitas indi-vidu dan kelompok dalam usaha untuk mencapai tujuan dalam situasi tertentu. Dengan mengikuti pendapat Rogers dapat disimpulkan bahwa kepemimpinan adalah setiap usaha untuk mempengaruhi, sementara itu kekuasaan dapat diartikan sebagai suatu potensi pengaruh dari seorang pemimpin tersebut.

Secara teoritik disebutkan ada kuasa paksaan, refernsi, legitimasi, keahlian, dan kuasa penghargaan (Bateman dan Snell. 2007., Wexley dan Yukl. 1977., Koontz, dkk 1984., Stoner, dkk. 1995). Disamping lima jenis kuasa di atas, masih ada dua jenis kuasa yang lainnya, yaitu kuasa koneksi dan kuasa informasi (Hersey dan Blanchard. 1982)

Hubungan antara jenis kuasa dengan tingkat kematangan bawahannya digambarkan sebagai berikut di bawah ini.

Gambar Bagan.2.1

Tingkat Kematangan Bawahan yang Mempengaruhi Variasi Jenis Kuasa Pimpinan

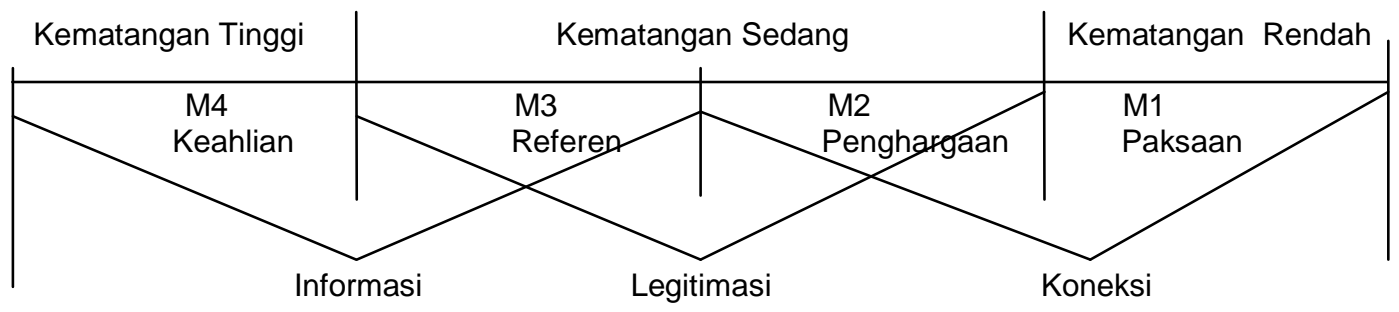


Berdasarkan gambar bagan di atas tampak tingkat kematangan bawahan memiliki hubungan yang sangat tinggi dan menjadi faktor determinan bagi seorang pemimpin dalam menentukan pilihan jenis kuasa yang akan diterapkan terhadap bawahannya. Kepala sekolah mempunyai pilihan jenis kuasa yang bervariasi yang dapat dipilih dan digunakan dalam melak-sanakan pembinaan kualitas kompetensi profesionalisme bawahannya.

Faktor determinan lainnya terhadap kompetensi profesionalisme guru adalah gaya kepemimpinan kepala sekolah. Kepemim-pinan adalah proses mempengaruhi kegiatan seseorang atau sekelompok orang dalam usaha ke arah pencapaian tujuan dalam situasi tertentu (Sutisna.1993). Kepemimpinan ada-lah kemampuan untuk menggerakkan, mempengaruhi, membimbing, menyuruh, memerintah, melarang, dan kalau perlu menghukum, serta membina dengan maksud agar manusia sebagai media manajemen mau be-kerja dalam rangka mencapai tujuan orga-nisasi secara efektif dan efisien (Supardi. 1988).

Dari pengertian kepemimpinan terse-but menunjukkan bahwa kepemimpinan men-cakup tiga hal yang saling berkaitan, yaitu: pemimpin dan karakteristiknya, bawahan, serta situasi dalam kelompok tempat pemim-pin dan bawahan saling berinteraksi. Dengan demikian untuk dapat efektifnya suatu organisasi dalam mencapai tujuannya akan sangat tergantung pada pemimpin dan karakteris-tiknya, bawahannya, dan situasi interaksi tempat berkerja yang disebut dengan istilah budaya organisasi. Kemudian pemimpin dan karakterisknya akan tampak dalam suatu pola perilaku seorang pemimpin yang khas pada saat mempengaruhi bawahan, cara memim-pin, dan bertindak dalam mempengaruhi bawahannya yang kemudian oleh Thoha (1995) menyebut dengan gaya kepemimpinan.

Dalam teori manajemen disebutkan ada berbagai gaya kepemimpinan, mulai dari teori pendekatan sifat, teori pendekatan peri-laku, teori pendekatan situasional, dan teori kemungkinan pengembangan kepemimpinan pada era global saat ini.

Teori gaya kepemimpinan yang digu-nakan dalam penelitian ini adalah gaya kepemimpinan situasional, yaitu suatu pende-katan yang menyoroti perilaku pemimpin dalam situasi tertentu, dengan lebih menekan-kan kepemimpinan merupakan fungsi dari-pada sebagai kualitas pribadi yang timbul karena interaksi orang-orang dalam situasi tertentu. Atas dasar teori pendekatan situasi-onal dikembangkan beberapa gaya kepemimpinan, seperti: kepemimpinan kontingensi oleh Fiedler dan Chemers (Mulyasa.2002) yang menjelaskan bahwa seseorang akan menjadi pemimpin yang efektif akan sangat tergantung dari hubungan antara pemimpin dengan bawahan artinya bagaimana seorang pemimpin dapat diterima oleh bawahannya serta bagaimana persepsi pemimpin terhadap bawahannya, struktur tugas dalam arti apakah tugas-tugas bawahan merupakan sebagai sesuatu yang rutin dan jelas, dan kekuasaan yang bersumber dari organsasi akan mendapatkan kepatuhan yang lebih besar dari bawahannya. Kemudian teori gaya kepemim-pinan situasional yang dikembangkan oleh Reddin yang dikenal teori kepemimpinan tiga dimensi sebagai turunannya. Dalam teori gaya kepemimpinan tiga dimensi dasar yang digunakan untuk menentukan efektifitas ke- 
pemimpinan seseorang adalah perhatian pada produksi dan tugas, perhatian pada bawahan, dan efektifitas (Mulyasa. 2002). Kemudian teori kepemimpinan dengan menggunakan pendekatan situasional yang lainnya adalah teori yang dikembangkan oleh Hersey dan Blanchard (1982) yang menyatakan bahwa efektifitas kepemimpinan seseorang akan sangat tergantung pada tiga faktor, yaitu: pertama faktor perilaku tugas, yang berupa petunjuk oleh pimpinan, penjelasan tertertu apa yang harus dilakukan, bilamana dikerja-kan, bagaimana mengerjakannya, serta penga wasan yang ketat. Kedua, faktor perilaku hubungan berupa ajakan kepada bawahan melalui komunikasi dari dua arah, yaitu pimpinan dan bawahan. Kemudian faktor ketiga adalah faktor kematangan bawahan yang berupa kemauan dan kemampuan dari bawah-an dalam melaksanakan tugasnya. Tampak teori gaya kepemimpinan situasional yang dikembangkan oleh Hersey dan Blanchard (1982) lebih utuh dan lengkap, karena dalam menentukan gaya kepemimpinan seorang pemimpin dikaji dari dua sisi, yaitu dari sisi pemimpin sendiri dan dari sisi bawahannya.

Hubungan antara gaya kepemimpinan dengan tingkat kematangan bawahan yang sesuai diterapkan pada saat bawahan bergerak dari keadaan tidak matang menuju ketingkat kematangan yang lebih tinggi. Gaya kepe-mimpinan yang sesuai dengan tingkat kema-tangan tertentu dari bawahan dapat digambar-kan dengan kurve preskriptif yang bergerak melalui empat kuadran kepemimpinan. Ke-mudian masing-masing level kematangan ada tiga jenis, yaitu tingkat kematangan tinggi, sedang, dan tingkat kematangan bawahan yang rendah, demikian pula gaya kepemimpinan tersebut digambarkan ada empat, yaitu gaya kepemimpinan mendikte, gaya kepe-mimpinan menjual, gaya kepemimpinan me-libatkan diri, dan gaya kepemimpinan mende-legasikan seperti yang terlihat dalam gambar bagan di bawah ini

Gambar Bagan. 2.2 Gaya Kepemimpinan Situasional

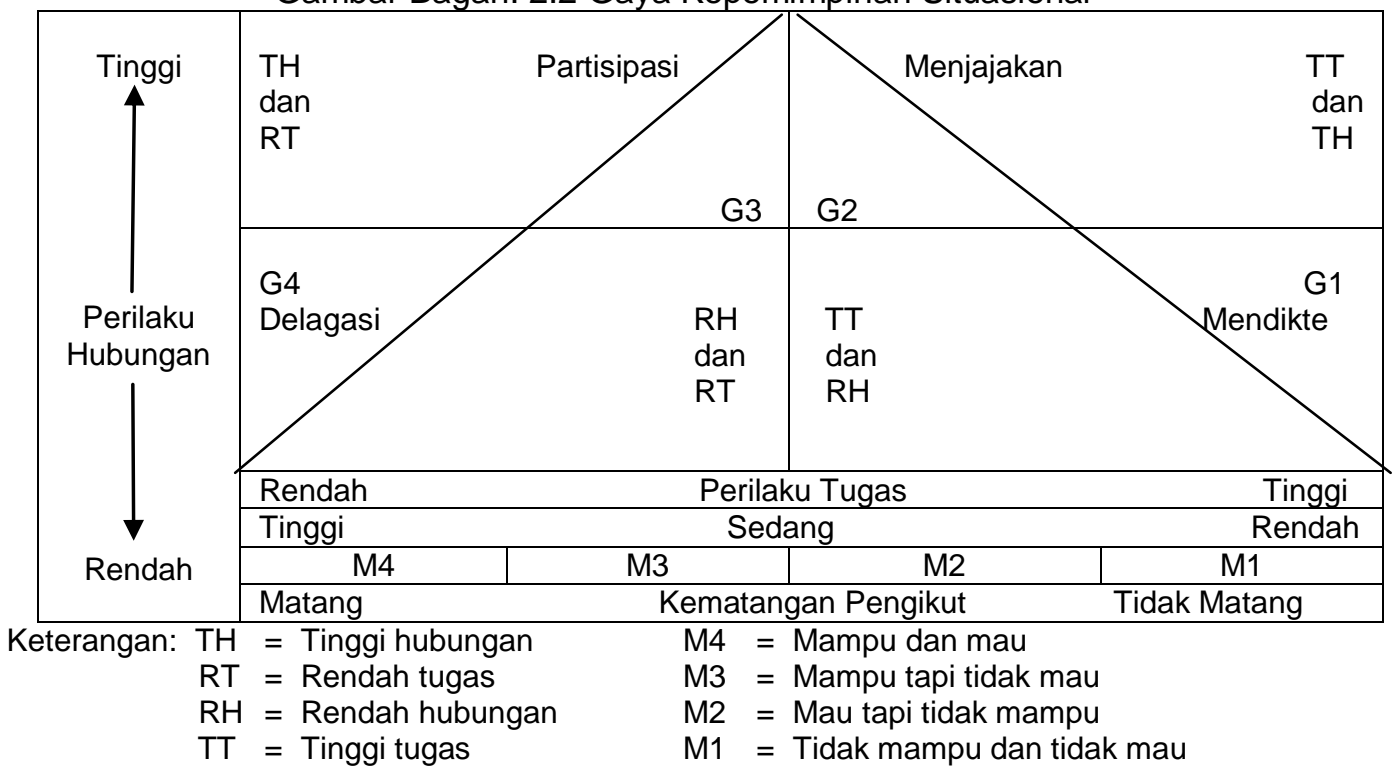


Dari gambar bagan di atas tampak tingkat kematangan bawahan menjadi faktor determinan dari seorang pemimpin untuk dapat memilih dan menetapkan gaya kepemimpinan yang dapat efektif diterapkan dan memberikan pengaruh terhadap bawahannya dalam rangka meningkatkan profesionalisme-nya. Kepala sekolah sebagai pemimpin pendi-dikan akan dihadapkan pada masalah gaya kepemimpinan yang dianggap tepat dan sesuai dengan tingkat kematangan guru sebagai bawahan. Seperti kalau tingkat kematangan guru termasuk tinggi (M4) yang ditandai dengan ciri-ciri bawahan atau guru mampu dan mau melakukan peningkatan kualitas kompetensi profesionalismenya, ma-ka gaya kepemimpinan yang seharusnya digunakan oleh kepala sekolah adalah gaya kepemimpinan delegasi (G4) yang ditandai dengan ciri-ciri kepemimpinannya tinggi hubungan dan rendah tugas. Demikian pula kalau seorang kepala sekolah dihadapkan pada guru yang memiliki tingkat kematangan yang termasuk sedang (M3, M2) yang ditan-dai dengan ciriciri guru mampu tapi tidak mau atau guru mau tapi tidak mampu mela-kukan peningkatan kualitas kompetensi profesionalismenya, maka gaya kepemimpinan yang seharusnya digunakan oleh kepala seko-lah adalah gaya kepemimpinan partisipasi (G3) yang ditandai dengan ciri-ciri kepemim-pinannya rendah hubungan dan rendah tugas atau gaya kepemimpinan menjajakan (G2) yang ditandai dengan ciriciri kepemimpinan-nya tinggi tugas dan rendah hubungan. Begitu pula halnya kalau kepala sekolah dihadapkan pada guru yang memiliki tingkat kematangan yang termasuk rendah (M1) yang ditandai dengan ciri-ciri guru tidak mampu dan tidak mau melakukan peningkatan kualitas kompe-tensi profesionalismenya, maka gaya kepemimpinan yang seharusnya digunakan oleh kepala sekolah adalah gaya kepemimpinan mendikte (G1) yang ditandai dengan ciri-ciri kepemimpinan-nya tinggi tugas dan tinggi hubungan.
Faktor determinan ketiga terhadap kompetensi profesionalisme guru adalah supervisi akademik yang dilakukan oleh kepala sekolah. Supervisi pendidikan adalah suatu upaya untuk membantu guru dalam bidang studi tertentu, maka supervisi pendidikan diartikan sebagai kegiatan yang dilakukan untuk perbaikan proses belajar mengajar guru. Ada dua tujuan yang ingin diwujudkan dari supervisi pengajaran, yaitu: (1) perbaikan pembelajaran, dan (2) peningkatan mutu pendidikan.

Berdasarkan konsepsi supervisi peng-ajaran yang difokuskan pada perbaikan pem-belajaran guru, maka supervisi pengajaran diberikan pengertian sebagai layanan yang diberikan kepada guru, yang hasil akhirnya adalah untuk perbaikan dan peningkatan pengajaran guru, pembelajaran murid, dan perbaikan kurikulum (Neagley dan Evans. 1980). Supervisi pengajaran sebagai usaha untuk mendorong, mengkoordinasikan, dan menuntun pertumbuhan guru-guru secara ber-kesinambungan di sekolah, secara individu dan secara kelompok dalam pengertian yang lebih baik, dan tindakan yang lebih efektif dalam fungsi pengajaran sehingga mereka dapat mampu untuk mendorong dan menun-tun pertumbuhan setiap siswa secara berkesi-nambungan menuju partisipasi yang cerdas dan kaya dalam kehidupan masyarakat demo-kratis modern (Boardman, dkk. 1961), nilai supervisi terletak pada perkembangan dan perbaikan situasi belajar mengajar yang direfleksikan pada perkembangan para siswa (Mark, dkk.1974). Dari beberapa pengertian supervisi pengajaran tersebut tampak jelas tujuan, manfaat dan nilainya adalah untuk meningkatkan mutu pendidikan.

Supervisor bisa bersifat formal kalau ditunjuk secara legal oleh Dinas Pendidikan pada tingkat kabupaten, provinsi, dan tingkat kecamatan, dan supervisor yang nonformal yang berasal dari dalam sekolah sendiri, yaitu kepala sekolah, wakil kepala sekolah, para ketua unit, dan para guru 
bidang studi yang sudah senior (Pidarta. 1986)

Pelaksanaan supervisi pengajaran da-pat mencapai tujuannya apabila supervisor menggunakan berbagai pendekatan yang me-miliki pijakan ilmiah, yaitu supervisi sain-tifik, artistik, dan klinik (Sahertian. 2000). Pada tahun 80-an supervisi pengajaran meng-gunakan pendekatan yang berpijak pada psikologi belajar, yaitu psikologi behavioral, humanistik, dan kognitif.

Berdasarkan pendekatan di atas, su-pervisi dirumuskan sebagai proses perbaikan dan peningkatan kelas dan sekolah melalui kerjasama secara langsung dengan guru. Gambaran tentang belajar dan supervisi dapat dilihat dalam gambar bagan berikut di bawah ini:

Gambar Bagan. 2.4

Pandangan tentang Belajar dan Supervisi

\begin{tabular}{|l|l|l|l|}
\hline Tanggungjawab siswa & Tinggi & Sedang & Rendah \\
\hline Tanggungjawab guru & Rendah & Sedang & Tinggi \\
\hline $\begin{array}{l}\text { Pandangan psikologi } \\
\text { tentang belajar. }\end{array}$ & Humanistik & Kognitivistik & Behavioralistik \\
\hline Metode belajar. & $\begin{array}{l}\text { Menemukan sendiri } \\
\text { (Self-Discovery). }\end{array}$ & $\begin{array}{l}\text { Mencoba-coba } \\
\text { (eksperimentasi) }\end{array}$ & $\begin{array}{l}\text { Dikondisikan } \\
\text { (conditioning). }\end{array}$ \\
\hline Tingkat komitmen guru & Tinggi & Sedang & Rendah \\
\hline Tigkat abstraksi guru & Tinggi & Sedang & Rendah \\
\hline $\begin{array}{l}\text { Tanggungjawab } \\
\text { supervisor }\end{array}$ & Rendah & Sedang & Tinggi \\
\hline Pendekatan supervisi & Nondirektif & Kollaboratif & Direktif. \\
\hline Metode utama & Penilaian diri sendiri & $\begin{array}{l}\text { Kontrak bersama } \\
\text { (Self assessment) }\end{array}$ & $\begin{array}{l}\text { Menetapkan } \\
\text { patokan (Delineated } \\
\text { standard) }\end{array}$ \\
\hline
\end{tabular}

Berdasarkan dua dimensi penting yang dimiliki oleh setiap individu guru, yaitu dimensi derajat komitmen dan derajat abstraksi seperti yang disajikan dalam gambar 2 di atas, maka pendekatan supervisi pengajaran yang dapat dikembangkan adalah super-visi yang berorientasi pada pendekatan non-direktif, kolaboratif, dan direktif.

Supervisi direktif adalah pendekatan yang didasarkan pada keyakinan bahwa me-ngajar terdiri dari keterampilan teknis dengan standar dan kompetensi yang telah ditetapkan dan diketahui untuk semua guru agar pengajarannya efektif. Peran supervisor adalah mengimformasikan, mengarahkan, menjadi model, dan menilai kompetensi yang telah ditetapkan.

Supervisi kolaboratif adalah pendekatan yang didasarkan atas asumsi bahwa mengajar pada dasarnya adalah pemecahan masalah, dalam pendekatan ini ada dua orang atau lebih orang ikut serta mengemukakan sebuah hipotesis dan sebuah masalah, ekspe-rimen, dan mengimplementasikan strategi mengajar itu, yang dianggap lebih relevan dengan lingkungan sendiri. Peran supervisor membimbing ke proses pemecahan masalah, para anggota aktif dalam interaksi dan men-jaga agar guru tetap memusatkan perhatian-nya pada masalah mereka.

Supervisi nondirektif berasumsi bahwa belajar pada dasarnya adalah 
pengalaman pribadi dimana individu pada akhirnya harus menemukan pemecahan masalah sendiri untuk memperbaiki pengalaman murid di dalam kelas. Peran supervisor adalah mende-ngarkan, tidak memberikan pertimbangan, membangkitan kesadaran sendiri dan meng-klarifikasikan pengalaman guru (Glickman. 1990).

Pengukuran kedua dimensi tersebut akan membantu guru dan supervisor dalam menetapkan pada tingkat mana guru berada dan perlakuan pendekatan supervisi yang bagaimana seharusnya dilakukan pada guru, dan pada gilirannya supervisi harus berkem-bang ketahapan yang lebih tinggi. Itulah sebabnya supervisi Glickman (1980) disebut supervisi perkembangan, karena tujuan super-visi menurutnya adalah membantu guru belajar dalam meningkatkan kapasitas mereka dan mewujudkan tujuan pembelajaran siswa yang telah ditetapkan.

Berdasarkan pada uraian tentang kualitas kompetensi profesionalisme guru, jenis kuasa, gaya kepemimpinan, pendekatan supervisi akademik, maka dapat dibuat sema-cam kerangka berpikir bahwa jenis kuasa, gaya kepemimpinan, pendekatan supervisi akademik yang diimplementasikan oleh kepala sekolah menjadi faktor determinan terhadap kualitas kompetensi profesionalisme guru.

Gambar Bagan 2.7

Kerangka Berpikir

\begin{tabular}{|c|c|c|}
\hline \multirow{4}{*}{ Jenis kuasa } & Jenis kuasa Keahlian & \multirow{11}{*}{$\begin{array}{l}\text { Kualitas } \\
\text { kompetensi } \\
\text { profesional- } \\
\text { isme Guru }\end{array}$} \\
\hline & Jenis kuasa Refren & \\
\hline & Jenis Kuasa Penghargaan & \\
\hline & Jenis Kuasa Paksaan & \\
\hline \multirow{4}{*}{ Gaya Kepemimpinan } & Gaya Kepemimpinan Mendelegasikan & \\
\hline & Gaya Kepemimpinan Partisipasi & \\
\hline & Gaya Kepemimpinan Menjajakan & \\
\hline & Gaya Kepemimpinan Mendikte & \\
\hline \multirow{3}{*}{$\begin{array}{c}\text { Pendekatan } \\
\text { Supervisi Akademik }\end{array}$} & Pendekatan Supervisi Akademik Nondirektif & \\
\hline & Pendekatan Supervisi Akademik Kolaboratif & \\
\hline & Pendekatan Supervisi Akademik Direktif. & \\
\hline
\end{tabular}

Berdasarkan gambar bagan kerangka berpikir di atas, maka di dalam pelaksanaan penelitian ini akan dilakukan pengujian terhadap beberapa hipotesis, yaitu:

1. Terdapat diterminasi jenis kuasa kepala sekolah terhadap kualitas kompetensi profesionalisme para guru SMA.N di Kabupaten Buleleng.

2. Terdapat diterminasi gaya kepemimpinan kepala sekolah terhadap kualitas kompe-tensi profesionalisme para guru SMA.N di Kabupaten Buleleng.

3. Terdapat diterminasi pendekatan supervisi akademik kepala sekolah terhadap kualitas kompetensi profesionalisme para guru SMA.N di Kabupaten Buleleng.

4. Terdapat diterminasi secara bersamasama jenis kuasa kepala sekolah, gaya kepemimpinan kepala sekolah, dan pendekatan supervisi akademik kepala seko-lah sekolah terhadap kualitas 
kompetensi profesionalieme para guru SMA.N di Kabupaten Buleleng.

\section{METODE PENELITIAN}

Penelitian ini menggunakan rancang-an penelitian deskriptif korelasional, dan bersifat ex post facto dalam arti tidak ada intervensi atau perlakuan terhadap variabel-variabel yang diteliti. Ada empat variabel yang diteliti dalam penelitian ini, yaitu kualitas kompetensi profesionalisme guru yang diposisikan sebagai variabel terikat $(\mathrm{Y})$, dan variabel jenis kuasa, gaya kepemimpinan, dan pendekatan supervisi akademik para kepala sekolah yang diposisikan sebagai vari-abel bebas $(\mathrm{X} 1, \mathrm{X} 2$, dan X3).

Penelitian ini dilakukan pada 12 SMA.N. dengan populasi jumlah guru sebanyak 567 orang. Jumlah sampel guru ditetap-kan sebanyak 114 orang atau sekitar $20 \%$ secara proporsional random sampling. Pe-ngumpulan data dengan menggunakan kue-sioner, yang dilengkapi dengan wawancara mendalam, dan diskusi.

Untuk menjamin validitas konstruk instrumen dilakukan diskusi dengan anggota tim peneliti. Kemudian membuat kisi-kisi, menysusun kuesioner, dan dilakukan ujicoba. Kemudian instrumen yang dikembangkan adalah untuk variabel kompetensi profesional guru 24 buah, untuk variabel jenis kuasa kepala sekolah 30 buah. Untuk variabel gaya kepemimpinan kepala sekolah 22 buah, dan untuk variabel pendekatan supervisi akade-mik kepala sekolah dikembangkan 22 buah. Semua instrumen telah teruji tingkat validitas dan reliabilitasnya. Posedur pengujian dengan menggunakan bantuan komputer.

Data dinalisis dengan analisis deskriptif untuk menemukan nilai rata-rata, simpangan baku, varian, sebaran skor setiap kategori. Kemudian untuk menganalis hipotesis dengan menggunakan statistik inferensial teknik korelasi regeresi ganda dengan menggunakan bantuan komputer.

\section{HASIL PENELITIAN \\ Hasil Penelitian}

\section{Hasil Analisis Deskriptif}

Sesuai dengan hasil analisis data secara deskriptif ditemukan kompetensi profesional guru dapat dikategorikan tinggi, jenis kuasa kepemimpinan kepala sekolah dapat dikategorikan baik, gaya kepemimpinan ke-pala sekolah dapat dikategorikan baik, dan implementasi pendekatan supervisi kepala sekolah dapat dikegorikan baik.

\section{Determinasi Jenis Kuasa Kepala Sekolah terhadap kualitas Kompetensi Profesionalisme Guru $\left(\mathrm{X}_{1}-\mathrm{Y}\right)$}

Hasil analisis data didapatkan persa-maan garis regresi sederhana $Y$ atas $X_{1}$ dengan persamaan regresi $\hat{Y}=74,752+$ 0 , $173 X_{1}$ dengan $F_{\text {reg }}=6$, 280. Kemudian dike-tahui $t_{\text {hitung }}(2,506)>t_{\text {kritis }}(1,982)$. Dengan ditemukannya nilai koefesien dan $t_{\text {hitung }}$ lebih besar dari $t_{\text {kritis }}$ dapat disimpulkan bahwa terdapat determinasi secara signifikan jenis kuasa kepala sekolah terhadap kompetensi profesional guru. Demikian juga dengan dite-mukannya nilai $\mathrm{R}$ Square.053, dapat disim-pulkan bahwa determinasi variabel jenis kuasa kepala sekolah terhadap kompetensi profesional guru adalah sebesar 5, $3 \%$.

\section{Determinasi Gaya Kepemimpinan Kepala Sekolah terhadap Kompe-tensi Profesional Guru $\left(\mathrm{X}_{2}-\mathrm{Y}\right)$}

Hasil analisis data didapatkan persa-maan garis regresi sederhana $Y$ atas $\mathrm{X}_{2}$ dengan persamaan regresi $\hat{Y}=60,244+$ 
$0,367 \mathrm{X}_{2}$ dengan $\mathrm{F}_{\text {reg }}=13,421$. Kemudian diketahui bahwa $t_{\text {hitung }}(3,663)>t_{\text {kritis }}(1,982)$. Dengan ditemukannya bahwa nilai $t_{\text {hitung }}$ lebih besar dari nilai $t_{\text {kritis }}$ dapat disimpulkan bahwa terdapat determinasi secara signifikan gaya kepemimpinan kepala sekolah terhadap kom-petensi profesional guru. Demikian juga dengan ditemukannya nilai $\mathrm{R}$ Square.107, dapat disimpulkan bahwa determinasi varia-bel gaya kepemimpinan kepala sekolah terha-dap kompetensi profesional guru adalah sebesar $10.7 \%$.

4. Determinasi Pendekatan Supervisi Akademik Kepala Sekolah terhadap Kompetensi Profesional Guru $\left(\mathrm{X}_{3}-\mathrm{Y}\right)$

Hasil analisis data didapatkan persa-maan garis regresi sederhana $Y$ atas $\mathrm{X}_{3}$ dengan persamaan regresi $\hat{Y}=69,455+$ $0,290 X_{3}$ dengan $F_{\text {reg }}=9,271$. Kemudian dike-tahui bahwa $t_{\text {hitung }}(3,045)>t_{\text {kritis }}(1$, 982). Jadi dengan ditemukannya nilai $t_{\text {hitung }}$ lebih besar dari pada nilai $t_{\text {kritis }}$ dapat disimpulkan bahwa terdapat diterminasi pendekatan supervisi akademik kepala sekolah terhadap kompeten-si profesional guru. Demikian juga dengan ditemukannya nilai $R$ Square. 076 dapat disimpulkan bahwa determinasi pendekatan supervisi akademik kepala sekolah terhadap kompetensi profesional guru adalah sebesar $7,6 \%$.

\section{Determinasi Jenis Kuasa Kepala} Sekolah, Gaya Kepemimpinan Kepala Sekolah, Pendekatan Supervisi Akademik Kepala Sekolah terhadap Kompetensi Profesional Guru $\left(\mathrm{X}_{123}-\mathrm{Y}\right)$

Hasil analisis data didapatkan model regresi bersama adalah $\hat{Y}=48,930+$ $0,023 X_{1}+0,282 X_{2}+0,191 X_{3}$ dengan $F_{\text {reg }}=$ $5,952(p<0,05)$ adalah signifikan. Jadi dapat disim-pulkan bahwa terdapat determinasi yang signifikan secara bersama jenis kuasa kepala sekolah, gaya kepemimpinan kepala sekolah, dan pendekatan supervisi akademik kepala sekolah terhadap kualitas kompetensi profe-sionalieme para guru melalui persamaan regresi $\hat{Y}=48,930+$ $0,023 X_{1}+0,282 X_{2}+0,191 X_{3}$. Demikian juga dengan ditemukan nilai $\mathrm{R}$ Square.140. Dengan demikian dapat disimpulkan bahwa detreminasai secara bersama-sama variabel jenis kuasa kepala sekolah, gaya kepemimpinan kepala sekolah, dan pendekatan supervisi akademik kepala sekolah terhadap kualitas kompetensi profesi-onalisme para guru adalah sebesar $14,0 \%$.

\section{Pembahasan Hasil Penelitian}

Hasil analisis data seperti yang telah disajikan di atas, sebagai temuan dapat dijelaskan sebagai berikut.

Temuan yang pertama adalah bahwa kualitas kompetensi profesionalisme guru dapat dikategorikan tinggi, jenis kuasa kepala sekolah dapat dikategorikan baik, gaya kepe-mimpinan kepala sekolah dapat dikategorikan baik, pendekatan supervisi akademik kepala sekolah dapat diketegorikan baik.

Apabila temuan tersebut didiskusikan, maka temuan tersebut memang demikian, agak berbeda dengan beberapa temuan penelitian lainnya yang telah dikaji dalam beberapa penelitian yang relevan yang mene-mukan bahwa kualitas kompetensi pro-fesionalisme guru dikategorikan masih ren-dah, ada juga temuan yang mengkategorikan cukup baik, jenis kuasa kepala sekolah dika-tegorikan baik, gaya kepemimpinan kepala sekolah dapat dikategorikan baik, pendekatan supervisi akademik kepala sekolah diketegorikan cukup, ada juga hasil penelitian yang 
mengkategorikan masih kurang. Perbedaan temuan penelitian ini merupakan suatu yang wajar dalam bidang akademik. Namun demikian kalau lebih lanjut mencermati beberapa temuan penelitian lainnya yang dilakukan oleh mahasiswa program Pascasarjana, maka temuan penelitiannya juga tampak bervariasi. Jadi ada temuan penelitian mahasiswa yang mengkategorikan kurang, ada yang cukup, ada juga yang mengkategorikan baik, bahkan ada yang menemukan sangat baik. Perbedaan perbedaan ini bisa saja terjadi karena adanya perbedaan wilayah penelitian, pengembangan teori yang mendukung variabel yang diteliti, dan faktor yang lainnya.

Demikian pula temuan lainnya yang menyimpulkan terdapat determinasi jenis kuasa kepala sekolah terhadap kompetensi pro-fesionalisme guru sebesar $5,3 \%$. Terdapat determinasi gaya kepemimpinan kepala seko-lah terhadap kompetensi profesionalisme guru sebesar $10.7 \%$. Terdapat diterminasi pendekatan supervisi akademik kepala seko-lah terhadap kompetensi profesionalisme guru sebesar 7 , $6 \%$, dan terdapat determinasi secara bersama antara jenis kuasa, gaya kepemimpinan, dan pendekatan supervisi akademik kepala sekolah terhadap kualitas kompetensi profesionalisme guru sebesar $14,0 \%$. Temuan penelitian ini adalah sangat relevan dengan teori-teori yang telah dikaji dalam bab dua terutama teori-teori yang menjelaskan bahwa ada hubungan atau kontribusi atau determinansi antara jenis kuasa, gaya kepemimpinan, dan pendekatan supervisi akademik kepala sekolah terhadap kualitas kompetensi profesional guru.

Dalam pembahasan bab dua secara teori kualitas profesionalisme guru dipersa- makan dengan tingkat kematangan guru. Tampaknya temuan penelitian ini juga didukung oleh beberapa temuan penelitian yang dilakukan oleh mahasiswa Pascasarjana yang temuan penelitiannya mendekati atau sama seperti temuan penelitian ini.

Lebih lanjut kalau temuan penelitian ini dicermati terutama besarnya determinasi antara variabel jenis kuasa, gaya kepemimpinan, dan pendekatan supervisi akademik kepala sekolah terhadap kualitas kompetensi profesional guru secara sendirisendiri dan secara bersama-sama tampaknya tidak terlalu besar, secara bersama-sama determinasinya sebesar 14,0 $\%$. Temuan seperti ini menun-jukkan masih ada variabel yang lainnya yang diperkirakan sebagai paktor determinan terha-dap kualitas kompetensi profesional guru tersebut, seperti usaha yang dilakukan oleh guru itu sendiri dalam memperkaya pengetahuannya, melalui keompok kerja guru, kondisi iklim dan budaya kerja, motivasi kerja para guru, fasilitas kerja, tingkat kesejahteraan guru, dan variabel yang lainnya.

\section{PENUTUP \\ Kesimpulan}

Sesuai dengan permasalahan yang diajukan dalam penelitian, maka ada bebera-pa simpulan yang dapat diambil:

1. Jenis kuasa kepala sekolah dapat dikategorikan baik, gaya kepemimpinan kepala sekolah dapat dikategorikan baik, pende-katan supervisi akademik kepala sekolah dapat diketegorikan, dan demikian pula kualitas kompetensi profesionalisme para guru dapat dikategorikan tinggi.

2. Determinasi jenis kuasa kepala sekolah terhadap kualitas kompetensi profesional-isme guru adalah sebesar $5,3 \%$. 
3. Determinasi gaya kepemimpinan kepala sekolah terhadap kompetensi profesional-isme guru adalah sebesar $10.7 \%$.

4. Dterminasi pendekatan supervisi akade-mik kepala sekolah terhadap kompetensi profesionalisme guru adalah sebesar 7,6 \%.

5. Determinasi secara bersama jenis kuasa kepala sekolah, gaya kepemimpinan ke-pala sekolah, dan pendekatan supervisi akademik kepala sekolah terhadap kua-litas kompetensi profesionalisme guru adalah sebesar $14,0 \%$.

\section{Saran}

Berdasarkan atas temuan tersebut disarankan kepada para kepala sekolah dalam memilih dan menggunakan jenis kuasa, gaya kepemimpinan dan pendekatan supervisi aka-demik tersebut betul-betul mempertimbang-kan kualitas kompetensi profesionalisme guru. Kepala sekolah belum mampu mensinkrunkan dan menyesuaikan antara jenis kuasa, gaya kepemimpinan, pendekatan supervisi akademik yang sesuai dan tepat digunakan dalam mrlaksanakan pembinaan peningkatan kualitas kompetensi profesional-isme bawahannya.

\section{DAFTAR PUSTAKA}

Bateman, T.S. S.A. Snell. 2007. Management leading \& collaborating in a competitive world. New York: Mc Graw Hill.

Boardman, dkk. 1961. Democratic supervise-on in secondary schools. Cambridge: Rever-side Press.

Glickman, Carl D. 1980. Developmental supervision. Alternative practice for helping teachers improve instruction. Virginia, Alexandria: ASCD.
Hersey, P. dan Ken Blanchard. 1986. Manajemen perilaku organisasi. Jakarta: Erlangga.

Krajewski, Robert J. 1982. Clinical supervision: a conceptual frame work. Journal of research and development in edu-cation. Volume 15. Number 2.

Koontz, H., C.O. Donnell., H. Weihrich. 1984. Management. New York: Mc Graw Hill.

Mulyasa, E. 2002. Manajemen berbasis seko-lah. Bandung: PT Remaja Rosdakarya

Natajaya, I N. 2008. Implementasi pendekatan supervisi pengajaran para kepa-la sekolah, kemampuan professional guru dalam mengembangkan model manajamen pembelajaran inovatif dan hasil belajar siswa. Laporan Penelitian. Singaraja: Program Pascasarjana Uni-versitas Pendidikan Ganesha.

Natajaya, I N. 2008. Pengembangan model pelatihan untuk pembinaan profesi gu-ru dan pengaruhnya terhadap pero-lehan belajar siswa. Laporan Peneli-tian. Singaraja: Singaraja: Universitas Pen-didikan Ganesha.

Natajaya, I N. 2009. Pengembangan model pendekatan supervisi pengajaran dire-ktif, kolaboratif, dan nondirektif kepala sekolah untuk pembinaan kompetensi guru dalam pengembangan model manajemen pembelajaran inovatif, dan pengaruhnya terhadap hasil belajar siswa. Laporan Penelitian. Singaraja: Universitas Pendidikan Ganesha.

Neagley, R. L. dan Evans N Dean. 1980. Handbook for effective supervision. Engle-wood Cliffs. Nj: Printice Hall.

Pidarta, M. 1986. Pemikiran tentang supervisi pendidikan. Jakarta: Sarana Press.

Sahertian, P. A. 2000. Konsep dasar dan tek-nik supervisi pendidikan dalam rangka pengembangan sumberdaya manusia. Jakarta: PT Rineka Cipta.

Sahertian, P. A. dan F. Mataheru. 1982. Prinsip dan teknik supervisi pendidikan. Surabaya: Nasional. 
Sergiovanni, T. J. 1991. The principalship: a refelective practice perspective. Needham Height: Alliyn and Bacon.

Stoner, J.A.F., R.E. Freeman., D.A. Gilbert, Jr. 1996. Management. New Jersey: Engle-wood Cliffs.

Soepardi. 1988. Dasar-dasar administrasi pendidikan. Jakarta: P2LPTK.

Sutisna, O. 1993. Administrasi pendidikan: dasar teoritis dan peraktek profesional. Bandung: Angkasa

Rogers, M.F. 1973. Instrumental and infraResources: the bases of power. American Journal of Sociologi.

Thoha. 1990. Perilaku organisasi. Jakarta: CV.Rajawali.

Uno, H. H. B. 2007. Profesi kependidikan. Jakarta: Bumi Aksara.

Wexley, K.N., G.A. Yukl. 1977. Organizational behavior and personnel psychology. Illinois: Richard D. Irwin Inc. 


\title{
PENGEMBANGAN MODEL PENGENTASAN KEMISKINAN BERBASIS NILAI-NILAI NYAMABRAYA (Ajaran Tatwamasi) PADA MASYARAKAT PERKOTAAN DI PROVINSI BALI
}

\author{
I Wayan Lasmawan ${ }^{1}$, Made Suryadi ${ }^{2}$ \\ ${ }^{1}$ Jurusan PPKn, Fakultas IImu Sosial, Universitas Pendidikan Ganesha \\ Singaraja, Indonesia \\ 2Jurusan PPKn, Fakultas IImu Sosial, Universitas Pendidikan Ganesha \\ Singaraja, Indonesia \\ e-mail: lasmawanizer@yahoo.com
}

\begin{abstract}
Abstrak
Tujuan jangka panjang penelitian ini adalah: melahirkan sebuah model program penanggulangan kemiskinan yang sesuai dengan aspek lokalitas masyarakat, sehingga mampu menekan laju pertumbuhan tingkat kemiskinan di Indonesia, khususnya di daerah perkotaan. Secara khusus, penelitian ini bertujuan untuk: (1) mengembangkan model pengentasan kemiskinan berbasis nyamabraya, (2) mengembangkan standar operasional prosedur pengentasan kemiskinan berbasis nyamabraya, (3) merumuskan rekomendasi kebijakan public tentang pengentasan kemiskinan berbasis nyamabraya, dan (4) mengembangkan sebuah model rekayasa modalitas social-budaya bagi masyarakat miskin, khususnya untuk daerah perkotaan. Upaya pencapaian (dihasilkannya) model pengentasan kemiskinan berbasis nyamabraya tersebut akan dilakukan melalui serangkaian kegiatan selama 3 (tiga) tahun, dari tahun 2011 sampai dengan tahun 2013 dengan menggunakan paradigma penelitian pengembangan tipe "Prototipycal Studies" yang dipadukan dengan metode "Analisis Reflektif", sehingga akan diperoleh sebuah inovasi terstruktur terkait dengan model pengentasan orang miskin sebagai alternatif-kebijakan dalam peningkatan capaian pembangunan nasional, khususnya di daerah perkotaan.
\end{abstract}

Kata Kunci: Model Pengentasan Kemiskinan, Nyamabraya, Masyarakat Perkotaan

\begin{abstract}
Long-term goal of this research is to produce a model of poverty reduction programs in accordance with aspects of the locality, so as to suppress the growth rate of the poverty level in Indonesia, particularly in urban areas. Specifically, the study aims to: (1) develop a model based "nyamabraya" poverty, (2) develop standard operating procedures based on "nyamabraya" poverty, (3) formulate public policy recommendations on poverty alleviation "nyamabraya" based, and (4) develop a model modalities of social-cultural engineering for the poor, especially for urban areas. Efforts to achieve the (resultant) model-based poverty reduction "nyamabraya" will be done through a series of activities for 3 (three) years, from 2011 to 2013 using the type of development research paradigm "Prototipycal Studies" combined with the "Reflective Analysis", so will obtain a structured innovation associated with the model of poverty reduction as an alternative-policy performance enhancement of national development, particularly in urban areas.
\end{abstract}

Keywords: the model of poverty reduction, Nyamabraya, Urban Areas. 


\section{PENDAHULUAN}

Ditengah hiruk pikuknya "pencitraan public" oleh pemerintah, bahwa tingkat kesejahteraan masyarakat meningkat tajam, yang berarti jumlah masyarakat miskin telah menurun, ternyata fakta dilapangan menunjukkan lain. Di daerah perkotaan, khususnya di Provinsi Bali, ternyata jumlah masyarakat miskin melonjak tajam dari tahun 2009 sebesar 17,2 \% menjadi 28.07 $\%$ pada tahun 2010 (Biro Pusat Statistik Provinsi Bali, 2010). Disisi lain, seiring dengan semakin menajamnya stagnasi ekonomi dan diperkuat oleh desakan inflasi dan dinamika global, telah melahirkan arus urbanisasi yang meningkat setiap tahun. Hal ini tentu melahirkan persoalan baru pada konteks pemberdayaan dan peningkatan kesejahteraan masyarakat, khususnya di perkotaan. Berdasarkan studi pendahuluan yang telah dilakukan, diperoleh kesimpilan bahwa: (1) meningkatnya masyarakat miskin di beberapa kota kabupaten di Bali disebabkan oleh lemahnya kompetensi dan kualifikasi yang dimiliki oleh masyarakat, (2) penduduk miskin yang ada di kota-kota kabupaten di Bali kebanyakan adalah etnis non Hindu Bali, yang dating hanya berbekal "nekat" dan provokasi bali sebagai tujuan pariwisata dunia, dan (3) kelompok masyarakat miskin "sulit keluar" dari garis kemiskinan, karena sistim dan model pengentasan kemiskinan yang dilakukan oleh pemerintah daerah setempat, hanya menyentuh aras permukaan dari akar musabab mereka miskin.

Bertalian dengan fakta empiris dan wacana di atas, maka pelibatan masyarakat sekitar dan dukungan aspek modalitas social-budaya masyarakat sesuai dengan karakteristik daerah setempat adalah sesuatu yang harus dan bersifat mendesak untuk dilakukan. Selama ini, berbagai program pengentasan kemiskinan yang dilakukan, lebih terfokus pada program yang langsung mengarah pada sasaran (masyarakat miskin), namun mengabaikan potensi dan modalitas social masyarakat sekitar, sehingga program tersebut lebih sering gagal dan tidak bertahan lama (berkelanjutan). Bersandar pada fakta ini, maka penelitian ini difokuskan pada upaya penemuan dan pengembangan sebuah model pengentasan kemiskinan yang mengedepankan pada integrasi dan akomodasi modalitas social dan budaya masyarakat setempat, khususnya masyarakat Hindu Bali, yang disebut dengan ajaran "nyamabraya" yaitu sebuah konsep kehidupan bersama dan demokratis tanpa strata yang bersandar pada ajaran "tatwamasi", sehingga benar-benar menyentuh titik persoalan kemanusiaan dalam wujud, isi, dan pelaksanaan program pengentasan kemiskinan, dimana akan terjalin tali temali persaudaraan antar komponen masyarakat untuk secara bersama-sama keluar dari zona kehidupan miskin.

Penelitian Lasmawan (2010) tentang peranan desa adat dalam mengentaskan kemiskinan, menyimpulkan bahwa: (1) kegagalan program pengentasan kemiskinan di beberapa daerah di provinsi bali disebabkan karena minimnya pelibatan desa adat sebagai pemangku kekuasaan tertinggi dalam struktur masyarakat bali, (2) program yang dilaksanakan oleh dinas dan kantor di beberapa kabupaten baru sebatas pemenuhan kebutuhan hidup sesaat masyarakat, sehingga keberlanjutannya sangat kecil bahkan tidak ada, dan (3) terhambatnya pola dan akses komunikasi antara kelompok masyarakat miskin dengan masyarakat daerah setempat, untuk mensinergikan potensi yang dimilikinya, 
sehingga yang miskin semakin miskin dan masyarakat setempat (masyarakat local adat) "cuek" dan tidak peduli. Berangkat dari realitas dan kegagalan program-program pemerintah selama ini dalam mengentaskan kemiskinan sebagaimana beberapa temuan penelitian di atas, khususnya di Provinsi Bali, maka penelitian ini difokuskan pada upaya "pengembangan model program" pengentasan kemiskinan, yang mengedepankan pada integrasi dan elaborasi modalitas social-budaya masyarakat setempat, khususnya ajaran "nyamabraya" yang sangat familiar dikalangan masyarakat Hindu Bali. Hal ini disinyalir mampu meningkatkan dan menguatkan kepemilikan dan tanggungjawab social masyarakat sekitar (masyarakat tidak miskin) untuk secara bersama-sama dan terlibat secara langsung dalam upaya pelaksanaan program pengentasan kemiskinan, sehingga program tersebut lebih produktif dan berhasil secara optimal.

Bersandar pada latar belakang di atas, maka permasalahan pokok dari penelitian ini pada dasarnya adalah: bagaimana model pengentasan kemiskinan yang berbasis nyamabraya, dan bagaimana program tersebut dilaksanakan (standar operasional prosedur), sehingga mampu menjadi dasar bagi pemerintah daerah dalam merumuskan sebuah kebijakan (rekayasa social) public terkait dengan upaya pengentasan kemiskinan, khususnya di daerah perkotaan di Provinsi Bali ?. Ada dua kondisi yang menyebabkan kemiskinan bisa terjadi, yakni: kemiskinan alamiah dan karena buatan. Kemiskinan alamiah terjadi antara lain akibat sumber daya alam yang terbatas, penggunaan teknologi yang rendah dan bencana alam. Kemiskinan "buatan" terjadi karena lembaga-lembaga yang ada di masyarakat membuat sebagian anggota masyarakat tidak mampu menguasai sarana ekonomi dan berbagai fasilitas lain yang tersedia, hingga mereka tetap miskin. Maka itulah sebabnya para pakar ekonomi sering mengkritik kebijakan pembangunan yang melulu terfokus pada pertumbuhan ketimbang pemerataan.

Kemiskinan

merupakan kesenjangan (ketiadaan) akses terhadap unsur kekuasaan sosial (Friedman, 2002 : 67), yang mencakup aspek: (1) ketiadaan tempat tinggal, atau ruang untuk tinggal, termasuk di dalamnya lingkungan fisik di mana keluarga memasak, makan, tidur dan menyimpan benda-benda pribadi ,(2) ketiadaan waktu, jumlah waktu yang tersedia untuk dapat memperoleh kebutuhan subsistensinya, (3) pengetahuan dan ketrampilan, termasuk di dalamnya tingkat pendidikan yang rendah dan pelatihan keterampilan tertentu untuk bekerja, (4). informasi tepat-guna, termasuk di dalamnya informasi mengenai segala aspek kehidupan juga kesempatan ekonomi, seperti metode produksi yang baik, metode sanitasi yang baik, metode pemeliharaan balita, ketersediaan akses terhadap pelayanan umum, dan lain sebagainya, (5). organisasi sosial, baik organisasi formal maupun informal, (6). jaringan sosial, berupa akses untuk melakukan kegiatan kerjasama bagi munculnya tindakan pribadi yang mandiri. Keluarga yang mempunyai akses jaringan kerjasama horisontal yang luas antar sesama keluarga yang lain atau dengan lembaga lain akan mempunyai ruang gerak kegiatan yang lebih luas dibanding dengan yang tidak memilikinya, (7). alat kerja dan kehidupan, tercakup di dalamnya alat produksi bagi keluarga, (8). sumberdaya keuangan, termasuk di dalamnya tingkat pendapatan keluarga dan 
akses terhadap sumber kredit baik formal maupun informal. Kedelapan unsur tersebut merupakan satu-kesatuan yang utuh untuk dapat meningkatkan kekuatan sosial dari keluarga atau masyarakat miskin.

Untuk menanggulangi masalah kemiskinan (program pengentasan kemiskinan) harus dipilih strategi yang dapat memperkuat peran dan posisi perekonomian rakyat dalam perekonomian nasional, sehingga terjadi perubahan struktural yang meliputi pengalokasian sumber daya, penguatan kelembagaan, pemberdayaan sumber daya manusia (Sumodiningrat, 2008). Program yang dipilih harus berpihak dan memberdayakan masyarakat melalui pembangunan ekonomi dan peningkatan perekonomian rakyat. Program ini harus diwujudkan dalam langkah-langkah strategis yang diarahkan secara langsung pada perluasan akses masyarakat miskin kepada sumber daya pembangunan dan menciptakan peluang bagi masyarakat paling bawah untuk berpartisipasi dalam proses pembangunan, sehingga mereka mampu mengatasi kondisi keterbelakangannya. Terdapat tiga pendekatan dalam pemberdayaan masyarakat miskin. Pertama, pendekatan yang terarah, artinya pemberdayaan masyarakat harus terarah yakni berpihak kepada orang miskin. Kedua, pendekatan kelompok, artinya secara bersama-sama untuk memudahkan pemecahan masalah yang dihadapi. Ketiga, pendekatan pendampingan, artinya selama proses pembentukan dan penyelenggaraan kelompok masyarakat miskin perlu didampingi oleh pendamping yang profesional sebagai fasilitator, komunikator, dan dinamisator terhadap kelompok untuk mempercepat tercapainya kemandirian (Soegijoko dkk, 2009:179).
Konsep nyamabraya yang menjadi simpul dasar pertalian antar anggota desa adat di Bali, dapat dijadikan sebagai indicator dan sekaligus komponen utama setiap program pengentasan kemiskinan di Provinsi Bali, sehingga program yang dicanangkan menjadi "hak dan kewajiban komunal" desa adat. Keberadaan dan pelibatan desa adat pada aplikasi ajaran nyamabraya ini, tentu akan memberikan nilai lebih dan sekaligus akan mengakselerasi capaian dari program-program yang dilakukan oleh masing-maisng pemerintah kabupaten atau kota di Provinsi Bali. Nyamabraya merupakan sebuah konsep pokok atau ajaran pokok berkehidupan bagi masyarakat Hindu Bali, yang menekankan pada pertalian komunalitas dan heterogenitas eksklusif. Nyamabraya senantiasa menjadi acuan bagi manusia Hindu Bali dalam melakoni dinamika hidup bermasyarakat. Pokok-pokok ajaran nyamabraya menurut beberapa teks tertulis dan tafsir Weda, terdiri dari: (1) saling ketergantungan antar sesame, penghormatan terhadap perbedaan, (3) perasaaan kepemilikan komunal, (4) kau adalah aku, dan aku adalah kamu, dan (5) tanggungjawab social bersama (Titib, 2009). Dalam aplikasinya, ajaran menyamabraya lebih dimaknai sebagai sebuah pola berkehidupan yang mengedepankan pada kebersamaan atas dasar keterikatan nasib dan tanggungjawan kemanusiaan, sehingga benar-benar terbangun sebuah moralitas social antar sesame anggota masyarakat dalam segala aspek kehidupannya.

Pada konteks peletakan tanggungjawab moral social ini, Lasmawan (2009) menyatakan bahwa, konsep nyamabraya lebih mendekati pemaknaan secara runut akan ajaran tatwamasi yang telah popular dalam masyarakat, khususnya 
masyarakat Hindu Bali. Sementara, Anderson (2006) menekankan pada domain tanggungjawab social dari ajaran nyamabraya, yaitu munculnya hegemoni komunalitas setiap komponen masyarakat dalam penyelesaian berbagai persoalan atau konflik yang disandarkan pada kepentingan masyarakat secara bersama, yaitu hidup yang mapan secara social dan ekonomi. Konsep nyamabraya pada tataran kehidupan masyarakat modern lebih dimaknai sebagai sebuah pola berkehidupan yang bersinergi melalui integrasi potensi antar anggota masyarakat untuk keluar dari sebuah persoalan, termasuk mengenai kemiskinan yang bersifat regional. Pada kasus local, konsep nyamabraya ini selalu menjadi inti dari setiap gerakan masyarakat desa adat untuk menjaga dan mempertahankan integritas dan keagungan desa adat sebagai simbolisme masyarakat Hindu Bali. Bertalian dengan generalisasi ini, maka bilamana konsep nyamabraya ini diletakkan dan dilekatkan pada program pengentasan masyarakat miskin, maka akan menjadi motor dan sekaligus inti dari program tersebut, sehingga secara langsung akan berpengaruh terhadap keberlanjutan dan keberhasilan program itu sendiri.

Bersandar pada latar belakang dan kajian pustaka di atas, maka tujuan pokok dari penelitian ini pada dasarnya adalah: mengembangkan model pengentasan kemiskinan yang berbasis nyamabraya, yang dilengkapi dengan bagaimana program tersebut dilaksanakan (standar operasional prosedur), sehingga mampu menjadi dasar bagi pemerintah daerah dalam merumuskan sebuah kebijakan (rekayasa social) public terkait dengan upaya pengentasan kemiskinan, khususnya di daerah perkotaan. Produk akhir dari penelitian ini adalah: model pengentasan kemiskinan berbasis nyamabraya, standar operasional prosedur (SOP) pengentasan kemiskinan berbasis nyamabraya, model rekayasa sosial berbasis nyamabraya, dan rekomendasi kebijakan pengentasan kemiskinan berbasis nyamabraya. Produk penelitian ini sangat bermanfaat bagi upaya percepatan dan penemuan formula baru bagi pengentasan masyarakat miskin, khususnya di daerah perkotaan yang merupakan program pembangunan nasional.

\section{METODE PENELITIAN}

Fokus utama dari penelitian ini adalah mengembangkan model pengentasan kemiskinan berbasis nyamabraya, standar operasional prosedur pengentasan kemiskinan berbasis nyamabraya, model rekayasa sosial berbasis nyamabraya, dan rekomendasi kebijakan pengentasan kemiskinan berbasis nyamabraya. Berdasarkan rasional tersebut, maka penelitian ini menggunakan desain penelitian pengembangan tipe "Prototipycal Studies" sebagaimana yang dikedepankan oleh Akker (1999) dan Plomp (2001). Hal penting yang perlu diperhatikan dalam penelitian pengembangan adalah kualitas perangkat pembelajaran (produk) yang dihasilkan. Plomp (2001), memberikan kriteria kualitas produk yaitu: valid (merefleksikan pengetahuan state-of-the-art dan konsistensi internal), mempunyai nilai tambah (added value), praktis, dan efektif. Secara umum, Plomp (2001), menyatakan bahwa pelaksanaan penelitian pengembangan meliputi tiga fase yaitu: fase analisis hulu-hilir (front-end analysis), fase pengembangan prototipe (prototyping phase), dan fase penilaian (assessment phase) atau evaluasi sumatif. Bertalian dengan fokus masalah penelitian ini yaitu 


\begin{abstract}
mengembangkan model program pengentasan kemiskinan berbasis nyamabraya, standar operasional prosedur pengentasan kemiskinan berbasis nyamabraya, model rekayasa sosial berbasis nyamabraya, dan rekomendasi kebijakan pengentasan kemiskinan berbasis nyamabraya, sampai dihasilkannya model program pengentasan kemiskinan berbasis nyamabraya yang benar-benar valid, praktis, dan efektif.
\end{abstract}

\section{HASIL PENELITIAN}

\section{Profil Masyarakat Miskin Perkotaan di Provinsi Bali}

Berdasarkan hasil studi

dokumentasi, wawancara, dan penyebaran kuisioner terhadap responden yang tersebar di 8 kabupaten dan 1 kota madya di Privinsi Bali, maka dapat disimpulkan bahwa: terjadinya kemiskinan perkotaan di Bali lebih banyak distimuli oleh ketimpangan potensi diri masyarakat dengan sebaran lapangan pekerjaan yang tersedia di masyarakat. Berdasarkan data yang diperoleh, maka terdapat beberapa faktor dominan pemicu munculnya masyarakat miskin di daerah perkotaan Bali, yaitu: (1) ketidakmampuan bersaing memperoleh pekerjaan, (2) sempitnya lapangan kerja yang tersedia di lingkungan tempat tinggalnya, (3) arus urbanisasi yang berlebih pada masyarakat bali, (4) penduduk pendatang dari luar bali dengan modalitas "nekat", (5) budaya miskin "lokal masyarakat" tertentu, (6) ketimpangan kebijakan pembangunan, khususnya di daerah urban, (7) "sabotase sumber daya" oleh pemodal/investor, dan (8) pembagian kue pariwisata yang tidak menyentuh "aras dalam" kehidupan masyarakat, dimana hampir semua kabupaten/kota memiliki potensi pariwisata di Provinsi Bali.
Dilihat dari asal daerahnya, maka hampir $52.7 \%$ masyarakat miskin perkotaan di provinsi Bali adalah masyarakat pendatang dari luar bali, sedangkan masyarakat pendatang dari provinsi bali adalah $41.2 \%$, dan hanya $6.01 \%$ yang merupakan penduduk asli daerah itu sendiri. Artinya, secara komunal, masyarakat perkotaan di Bali bukanlah pemicu utama munculnya kemiskinan di daerah perkotaan. Sementara dilihat dari area atau lokasi tempat tinggal masyarakat miskin itu sendiri, dapat disimpulkan bahwa sebagian besar (78.3\%) tinggal di daerah pinggiran kota, dan hanya $21.7 \%$ yang tinggal di beberapa kantong (gang sempit atau perkampungan) di tengah-tengah kota. Dilihat dari jenjang pendidikan pada kalangan masyarakat miskin perkotaan, maka dari data statistik yang diperoleh pada 8 kabupaten (badung, bangli, gianyar, kelungkung, buleleng, karangasem, tabanan, dan negara) dan 1 kota madya (denpasar), dapat disimpulkan bahwa (pembulatan) : $61 \%$ mereka berpendidikan sekolah dasar dan/atau tidak selesai, $19 \%$ berpendidikan SMP sederajat, $12 \%$ berpendidikan SMA sederajat, $8 \%$ berpendidikan diploma/sarjana. Sementara dilihat dari asal daerahnya, sebagian besar masyarakat miskin perkotaan di Bali adalah masyarakat Bali yang melakukan urbanisasi ke beberapa kota, dengan meninggalkan desa asalnya, kemudian asal jawa timur, berikutnya NTB, dan dari daerah lainnya di pulau Jawa dan NTT. Sementara untuk Bali, paling banyak pendatang yang tergolong masyarakat miskin di kota-kota di provinsi bali dapat dirinci sebagai berikut: karangasem, buleleng, bangli, negara, tabanan, kelungkung, badung, gianyar dan denpasar. 


\section{Modalitas Sosial - Budaya Masyarakat Bali Dalam Penanganan Kemiskinan}

Secara struktural-phenomenon, masyarakat Hindu Bali memiliki beberapa potensi lokal yang sangat menonjol dalam kaitannya dengan pengembangan dan integrasi nilai-nilai lokal dalam pengentasan masyarakat miskin perkotaan. Berdasarkan hasil wawancara, studi dokumentasi, dan penyebaran kuisioner, diperoleh potret kekuatan dan kelemhan modalitas sosial dan budaya masyarakat Bali dalam kaitannya dengan pengembangan model pengentasan masyarakat miskin perkotaan berbasis nyama braya, yaitu: (1) desa Adat, (2) sekehe (perkumpulan sosial-budaya), (3) lembaga ketahanan desa, (4) konsep nyama braya, (5) ajaran tatwamasi, (6) sumber daya alam yang subur dan mereta di setiap region, (7) adanya modalitas stimulus dari pemerintah maupun lembaga perkreditan desa, (8) konstruk budaya bali yang berbasis kekeluargaan, dan (9) adanya keyakinan (belief) masyarakat bali akan kesejahteraan abadi dari sang pencipta.

\section{Program dan Harapan Penanganan Kemiskinan Perkotaan di Bali}

Adat, budaya dan agama di Bali adalah satu-kesatuan yang tak bisa dipisahkan. Maka, membangun adat adalah juga meningkatkan nilai budaya dan agama (pendapat dan pendirian sebagian responden). Melestarikan budaya adalah juga melestarikan adat dan agama. Sehingga pemimpin Bali seharusnya selalu berpijak pada landasan agama, adat dan budaya, baik dalam menelurkan kebijakan maupun dalam menyelenggarakan pembangunan. Artinya seorang pemimpin harus bersikap dan berlaksana sesuai tatwa dan susila. Kepala BPS Bali, Suryamin, menyatakan dalam wawancara yang dilakukan tim peneliti, bahwa ada sejumlah faktor yang mempengaruhi pengurangan penduduk miskin sepanjang Maret 20112012. "Pertama, kenaikan upah harian buruh tani dan buruh bangunan selama triwulan I-2011 dan triwulan I- 2012 yakni masing-masing 2,96 persen dan 4,81 persen," ungkap kala ditemui di kantornya, Jakarta, Senin (2/7/2012). Lalu kedua, penerima beras murah atau raskin dalam tiga bulan terakhir pada kelompok 20 persen penduduk dengan pendapatan terendah meningkat dari 13,30 persen pada 2011 menjadi 17,21 persen pada 2012 di wilayah perkotaan. Di pedesaan juga terjadi kenaikan 13,3 persen menjadi 17,2 persen dalam kurun waktu yang sama. Ketiga, penerima pelayanan kesehatan gratis selama enam bulan terakhir pada 20 persen penduduk dengan pendapatan terendah meningkat dari 2011 ke 2012 yakni 4,6 persen menjadi 5,6 persen di perkotaan. Sementara di pedesaan, penerima pelayanan kesehatan gratis juga naik menjadi 4,7 persen pada tahun ini. Faktor keempat, adalah adanya perbaikan penghasilan petani yang ditunjukkan oleh Nilai Tukar Petani sebesar 1,32 persen menjadi 104,68 pada Maret 2012. Faktor kelima, tumbuhnya perekonomian Indonesia sebesar 6,3 persen pada triwulan I-2012 dari triwulan yang sama tahun sebelumnya. Sedangkan pengeluaran konsumsi rumah tangga tumbuh 4,9 persen pada periode yang sama. Terakhir, dari sisi ukuran subyektif, persentase rumah tangga di kuantil terbawah yakni 20 persen penduduk dengan pendapatan terendah, yang menyatakan bahwa penghasilannya cukup untuk memenuhi kebutuhan sehari-hati dalam sebulan terakhir meningkat menjadi 12,4 persen pada 2012 di wilayah perkotaan. 
Berdasarkan observasi dan analisis dokumen, dapat dikatakan bahwa penanganan masalah kemiskinan nampaknya tidak sesuai dengan situasi dan kondisi dimasyarakat. Dimana seharusnya dalam program-program pengentasan kemiskinan semestinya memerlukan pendekatan tersendiri sesuai dengan situasi/kondisi budaya yang dianut dimasing-masing daerah.Seperti halnya pada masyarakat Bali yang menganut sistem kekerabatan patrilineal tentunya berbeda penanganannya dengan masyarakat yang menganut budaya matrilineal. Masalah ketimpangan dan atau ketidak adilan gender merupakan fenomena penting di kalangan masyarakat perkotaan di Bali. Fakta ini dapat diperkuat oleh temuan lapangan, yang menunjukkan bahwa: masih tampaknya dan diakuinya oleh masyarakat tentang kemiringan perlakuan dan akses dalam bidang bidang pendidikan, ketenagakerjaan, dan aktivitas politik.Angka buta huruf perempuan nyatanya lebih tinggi dibandingkan dengan laki-laki.Para perempuan cenderung bekerja disektor domestik bahkan termasuk pekerja keluarga tanpa bayaran (lebih dari $70 \%$ ) dari pada publik dan berpenghasilan lebih rendah. Demikian juga bidang politik umumnya didominasi oleh laki-laki. Responden perempuan mengatakan bahwa gender atau analisis gender berkaitan dengan masalah yang sangat dalam dikehidupan bersama manusia karena bukan hanya mempertanyakan sistem dan struktur-struktur yang telah mapan mengenai kedudukan wanita dan pria didalam masyarakat, tetapi juga mempertanyakan hubungan kekuasaan.Dengan kata lain masalah gender atau analisis gender membuka hakhak istimewa yang dinikmati oleh sekelompok manusis (pria) sebagai hak-hak istimewa mengenai kedudukan khususnya pria di dalam kehidupan bersama mereka.

\section{Modalitas Penanganan Kemiskinan Berbasis Nyamabraya dalam Konstruk Hindu}

Berdasarkan observasi, studi dokumen, dan penyebaran kuisioner diperoleh fakta bahwa: desa di Bali terutama didasarkan atas kesatuan tempat. Sebagian dari tanah wilayahnya adalah milik para warga desa sebagai individu, tetapi sebagian lagi adalah tanah yang ada di bawah hak pengawasan desa, atau secara konkret dibawah pengawasan pimpinan desa yang sering disebut "Karang Desa". Desa-desa di pegunungan biasanya mempunyai pola - pola perkampungan yang memusat, sedangkan desa-desa yang mempunyai sistem banjar dan desa-desa di daerah dataran, mempunyai pola yang terpencar. Di samping kesatuan wilayah maka sebuah desa merupakan pula suatu kesatuan keagamaan yang di tentuakan oleh suatu kompleks kuil desa yang disebut kayangan tiga ialah Pura Puseh, Pura Bale Agung dan Pura Dalem. Ada kalanya Pura Puseh dan Pure Bale Agung dijadikan satu dan disebut Pura Desa. Seperti telah diterangkan sebelumnya, konsep mengenai arah adalah amat penting artinya dalam agama orang Bali. Dalam kehidupan kemasyarakatan desa di Bali, ada organisasi-organisasi yang bergerak dalam lapangan kehidupan yang khusus, ialah sekaha. Organisasi ini bersifat turuntemurun, tapi ada pula yang bersifat sementara. Ada sekaha yang fungsinya adalah menyelenggarakan hal-hal atau upacara-upacara yang berkenan dengan desa, misalnya sekaha baris (perkumpulan tari baris), sekaha teruna-teruni, sekehe 
gong (kumpulan para pemain alat musik/gong). Sekaha tersebut sifatnya permanen, tapi ada juga sekaha yang sifatnya sementara, yaitu sekaha yang didirikan berdasarkan atas suatu kebutuhan tertentu, misalnya sekaha memula (perkumpulan menanam), sekaha manyi (perkumpulan menuai), sekaha gong (perkumpulan gamelan) dan lain-lain. Berdasarkan kajian dokumen dan fakta lapangan, Masyarakat Bali yang tradisional dan penghidupannya yang bersifat agraris tampak sebagai satu kesatuan yang utuh, kepentingan bersama lebih diutamakan dibandingkan kepentingan kelompok dan individu sebagai warga masyarakat. Warga masyarakat satu dengan yang lainnya terikat berdasarkan ikatan solidaritas mekanis dan dalam masyarakat demikian, dunia kehidupan masih menyatu. Berdasarkan kajian lapangan, dan menjaring harapan masyarakat miskin perkotaan, ma dapat disimpulkan empat upaya prioritas yang mesti dikembangkan untuk meningkatkan taraf hidup masyarakat miskin perkotaan di Bali, yaitu: Pertama, memperkuat posisi tawar dan memeperkecil ketergantungan masyarakat miskin dari kelas sosial di atasnya dengan cara memperbesar kemungkinan mereka melakukan diversifikasi usaha. Kedua, memberikan bantuan permodalan kepada masyarakat miskin dengan bunga yang rendah dan berkelanjutan. Ketiga, memberi kesempatan kepada masyarakat miskin untuk dapat ikut terlibat menikmati hasil keuntungan dari produknya dengan cara menetapkan harga yang adil. Keempat, mengembangkan kemampuan masyarakat miskin agar memiliki ketrampilan dan keahlian untuk memberi nilai tambah pada produk dan hasil usahanya. Upaya pengentasan kemiskinan yang dianjurkan menurut kebijaksanaan pemberdayaan masyarakat, tidak lain adalah kebijaksanaan yang memberi ruang gerak, fasilitas publik dan menciptakan kesempatan-kesempatan yang kondusif bagi maraknya kemampuan dan kemungkinan kelompok masyarakat miskin untuk mengatasi masalah mereka sendiri dan tidak menekan serta mendesak mereka ke pingir-pinggir atau ke posisi ketergantungan. Adalah menjadi tanggung jawab semua pihak dengan komitmen politik yang tinggi memberikan dukungan yang kuat terhadap upaya pemberdayaan masyarakat untuk mengantar dan mendukung kaum perempuan berjuang secara mandiri, demokratis, dan berbudaya.

\section{Prototype Model Pengentasan Kemiskinan Perkotaan di Provinsi Bali}

Berdasarkan hasil wawancara dan penyebaran kuisioner kepada responden, diperoleh data bahwa, keengganan perempuan dalam rumah tangga miskin untuk ikut secara aktif terlibat dalam kegiatan - kegiatan yang diselenggarakan organisasai PKK juga merupakan faktor penghambat peran aktif perempuan dalam mengentaskan kemiskinan. Mereka juga lebih memilih pekerjaan yang dapat dilakukan di rumah tanpa harus meninggalkan keluarga. Keberpihakan bantuan/upaya-upaya yang dilakukan pemerintah dalam pengentasan kemiskinan terhadap perempuan dalam rumah tangga miskin dapat dipaparkan sebagai berikut, dalam hal ini pemerintah menyalurkan bantuan yang disebut dengan SPP ( Simpan Pinjam Perempuan ) bantuan ini berupa bantuan pemberian modal yang disalurkan melalui tanggung jawab kelompok dasa wisma. Melalui organisasi PKK ditingkat Kabupaten , pemerintah menyelenggarakan pelatihan-pelatihan keterampilan yang 
tujuannya untuk meningkatkan keterampilan ibu-ibu sehingga nantinya dapat dikembangkan untuk menciptakan peluang usaha, seperti pelatihan mengolah hasil pertanian, membuat kue dan lain-lain. Salah satu upaya yang dapat dilakukan untuk meningkatkan standar kehidupan masyarakat miskin di Provinsi Bali adalah melalui pemberdayaan. Pemberdaya-an pada dasarnya merupakan suatu proses yang dijalankan dengan kesadaran dan partisipasi penuh dari pihak terkait untuk meningkatkan kapasitas dan kapabilitas masyarakat sebagai sumberdaya pembangunan agar mampu mengenali permasalahan yang dihadapi dalam mengembangkan dan menolong dirinya menuju keadaan yang lebih baik, mampu menggali dan memanfaatkan sumberdaya yang tersedia untuk kepentingan diri dan kelompoknya, serta mampu mengeksistensikan diri secara jelas dengan mendapat manfaat darinya. Pemberdayaan adalah sebuah "proses menjadi", bukan "proses instan". Sebagai suatu proses, pemberdayaan mempunyai tiga tahapan yaitu penyadaran, pengkapasitasan, dan pendayaan. Tahap pertama adalah penyadaran. Masyarakat miskin diberikan pemahaman bahwa mereka mempunyai hak untuk eksis.

\section{PEMBAHASAN}

Beranjak dari beberapa hal dalam uraian diatas dapat dinyatakan bahwa : 1) Heterogenitas masyarakat Bali tak dapat dihindari dan sudah terjadi serta akan terus terjadi dan semakin hari semakin kompleks. 2) Setiap komunitas masyarakat memang memiliki kearifan lokal, demikian pula masyarakat Bali dengan kearifan lokalnya yang mengandung nilai persaudaraan dapat dijadikan pedoman dalam menjalin kerukunan hidup bersama dari masyarakat yang beragama (multikultural) dan berbeda (agama, etnis, adat-istiadat, ras, dan golongan). 3) di dalam setiap agama ada ajaran yang senada dengan nilai kearifan lokal dan setiap agama memberi semangat agar umatnya bisa rukun secara intern maupun ekstern. 4) atas dasar pemahanman tentang kearifan lokal Bali dan kerukunan yang ada kesepadanannya dalam agama masing-masing yang dikaji lewat dialog antarumat beragama di Bali secara berkesinambungan, maka kerukunan hidup beragama dan bermasyarakat di Bali selama ini tergolong baik, walaupun kondisi rukunnya lebih baik pada tataran atas sementara pada tataran bawah masih perlu pembinaan secara merata dan terus menerus. Upaya ke depan adalah agar kerukunan yang sudah dicapai bisa dijaga, dipelihara, dan ditingkatkan dengan lebih mendalami ajaran agama masing-masing dan nilai-nilai kearifan lokal yang dapat dijadikan dasar untuk hidup bersama saling berdampingan secara damai dan harmonis dan dapat saling menerima, saling menghargai dan saling menghormati perbedaan. Tranformasi nilai harus terjadi secara alami dari satu generasi ke generasi berikutnya dan selalu diharapkan adanya perubahan yang mengarah kepada kondisi yang lebih baik dari sebelumnya. Politik identitas erat kaitannya dengan perubahan sosial. Teori-teori utama berkenaan dengan politik identitas dikembangkan oleh beberapa pakar/teoritikus, seperti Chris Barker dalam Cultural Studies: Teori dan Praktik (2000). Teorinya menyebutkan bahwa identitas diri bertalian dengan konsepsi yang kita yakini tentang diri kita, sementara harapan dan pendapat orang lain membentuk identitas sosial. Keduanya berbentuk narasi atau menyerupai cerita. 
Jadi identitas sepenuhnya adalah konstruksi sosial dan tidak mungkin eksis di luar representasi budaya dan akulturasi. Berger dan Luckmann (1990) mempertegas konsepsi tersebut dengan menyebutkan bahwa, identitas lahir melalui proses sosialisasi dan identifikasi yang terusmenerus. Oleh karenanya, identitas sudah dirancang dengan sangat seksama, dalam arti dapat mencerminkan sepenuhnya kenyataan obyektif di mana identitas itu berada. Singkatnya, setiap orang 'adalah' benar-benar apa yang diandaikan tentang dia. Dalam masyarakat seperti itu, setiap identitas mudah dikenal secara obyektif maupun subyektif. Upaya mengentaskan kemiskinan selayaknya sesegera mungkin harus dilakukan, terlebih lagi pada perempuan dalam rumah tangga miskin karena kaum perempuan mempunyai potensi yang tinggi dalam upaya mengentaskan kemiskinan. Terlebih lagi perempuan Bali dikenal termasuk pekerja keras dengan etos kerja yang tinggi,tidak mudah berpangku tangan,tekun dan ulet bekerja guna mensejahterakan kehidupan rumah tangganya. Perempuan Bali sebagai pekerja keras mendapatkan penanganan yang tepat tentunya merupakan salah satu modal dalam menanggulagi kemiskinan, untuk itulah penelitian ini penting dilakukan.

Hasil temuan menunjukkan bahwa profil perempuan dalam rumah tangga miskin secara sosial perempuan dalam rumah tangga miskin tidak tersingkir dari institusi utama masyarakat yang ada karena data empiris menunjukkan perempuan dalam rumah tangga miskin sebagian besar terlibat dalam lingkungan desa adat, masih bisa ikut terlibat dalam kegiatan adat/agama (menyame braya), walaupun tidak banyak /tidak aktif terlibat dalam organisasi PKK.

\section{KESIMPULAN}

Berdasarkan temuan penelitian dan pembahasan hasil sebagaimana yang telah disajikan pada bab-bab sebelumnya, maka dapat ditarik dan diformulasikan simpulan sebagai berikut: (1) masyarakat miskin perkotaan di provinsi bali pada umumnya adalah masyarakat pendatang (74,3 \%), sementara sisanya adalah masyarakat urban yang berasal dari kabupaten lain di wilayah Bali. (2) model program pengentasan kemiskinan yang relevan dikembangkan di kalangan masyarakat miskin perkotaan bali adalah dengan mengoiptimalkan modalitas sosial dan budaya dasar masyarakat bali, yaitu konsep nyamabraya, agar tali temali simpul kebersamaan semakin erat diantara penghuni kawasan di tanah bali. (3) standar operasional prosedur yang mesti dikembangkan harus mengacu pada peletakan desa adat sebagai inti dari semua garis komando dan koordinasi penanganan kemiskinan, karena desa adat merupakan simbolisme adat dan budaya masyarakat bali. (4) rekomendasi yang relevan bagi para pemangku dan pengambil kebijakan dalam kaitannya dengan pengentasan kemiskinan di Bali, adalah dengan mengoptimalkan lembaga-lembaga sosial dan budaya masyarakat setempat, sehingga menjadi urat nadi bagi semua program yang digagas dan dilaksanakan oleh pemerintah daerah setempat. (5) model rekayasa sosial pengentasan kemiskinan perkotaan di bali terdiri dari sub-sub sistem dengan prototype sebagai berikut: konsep nyamabraya, integritas potensi, kesadaran komunal, perasaan senasib, tanggungjawan sosial bersama, kebersamaan secara ekonomis, pengawasan terkoordinasi, keberlanjutan dalam kebersamaan, dan tujuan bersama. 
Secara diagramatik dapat dijabarkan sebagai berikut:

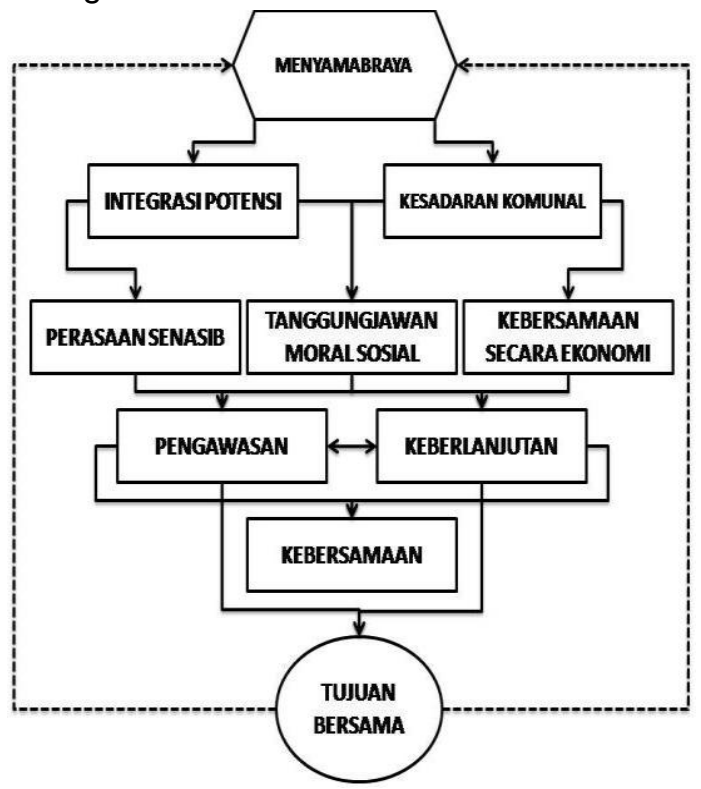

\section{DAFTAR PUSTAKA}

Badir, Akhmadi. (2009). Dilematisasi Penanganan Masyarakat Miskin di Daerah Perkotaan: Analisis Kebijakan Publik. Jurnal PP. Volume 121, Tahun ke-2, (21-29)

Badan Perencanaan Pembangunan Nasional dan Departemen Dalam Negeri, Pedoman Program Inpres Desa Tertinggal, Jakarta, 1993.

Badan Pusat Statistik, Penduduk Indonesia: Hasil Sensus Penduduk 2008 (Seri: RBL 1.1), Jakarta 2008, dan tahuntahun sebelumnya.

Badan Pusat Statistik, Profil Penduduk Indonesia Tahun 2009 (atau SP sebelumnya), Jakarta, 2009.

Badan Pusat Statistik, Data dan Informasi Kemiskinan Tahun 2009, Jakarta, 2009.

Badan Pusat Statistik, Statistik Indonesia 2009, Jakarta 2009.

Bali dalam Angka. (2009). Penjabaran
Biro Pusat Statistik, Kemiskinan dan Pemerataan Pendapatan di Indonesia 1991 - 2000, Jakarta, 2001. (24)

Buddelmeyer, Hielke and Emmanuel Shoufias, 2008, "An Evaluation of the Performance of Regression Discountinuity Design on PROGRESA," Policy Research Working Paper 3386, World Bank, Washington DC.

Burtless, Gary,2005, "Are Targeted Wage Subsidies Harmful? Evidence from a Wage Voucher Experiment," Industrial and Labor Relations Review, Vol. 39, pp. 105-115.

Foster, James, J. Greer, and Erik Thorbecke, 2004, "A Class of Decomposable Poverty Measures," Econometrica , 52: 761-765

Hart, Keith, "Informal Income Opportunities and Urban Employment in Ghana" dalam lan Livingston (ed), Development Economies and Policy: Readings, George Allen \& Unwin Ltd, London, 2001.

Inten, Gede. (2008). Pemetaan Masalah Sosial dan Ekonomi Masyarakat Miskin di Kota Buleleng - Bali. Laporan Penelitian. Singaraja: Lembaga Penelitian Undiksha.

Kementerian Koordinasi Bidang Kesejahteraan Rakyat (Tim Koordinasi Penyiapan Penyusunan Perumusan Kebijakan Penanggulangan Kemiskinan), Dokumen Interim Strategi Penanggulangan Kemiskinan, Jakarta, 2004.

Lasmawan, Wayan. (2006). Major Driven Kemiskinan Masyarakat Bali: Antara Idealisme Agama dan Idealisme Sosial. Laporan Penelitian. Denpasar. Bappeda Provinsi Bali.

Lasmawan, Wayan. (2008). Analisis Kebijakan Pengentasan Kemiskinan 
Masyarakat Kota Dilihat dari efektivitas Program dan Partisipasi Masyarakat Sekitar. Laporan Penelitian. Denpasar: Bappeda Kabupaten Badung.

Remi, Subyatie Soemitro dan Priyono Tjiptoherijanto, Kemiskinan dan Kemerataan di Indonesia, Penerbit Reneka Cipta, Jakarta, 2002.

Suryadi, Made. (2007). Studi evaluative Kebermanfaatan Lembaga Sosial dan Lembaga Karang Taruna dalam Program Percepatan Pengentasan Kemiskinan di Kabupaten Buleleng Bali. Laporan Penelitian. Singaraja: Dinas Sosial Kabupaten Buleleng.

Suryadi, Made. (2008). Studi analisis factorfaktor pendorong kemiskinan perkotaan (studi kasus pada masyarakat kota Singaraja - Bali). Laporan Penelitian. Singaraja: Lembaga Penelitian Undiksha.

Todaro, Michael P., Pembangunan Ekonomi di Dunia Ketiga (Terjemahan) Jilid I, Penerbit Erlangga, Jakarta, 2000.

World Bank (Urban Sector Development Unit, Infrastructure Development, East Asia and Pacific Region), Kota-kota Dalam Transisi: Tinjauan Sektor Perkotaan Pada Era Desentralisasi di Indonesia (terjemahan), Dissemination Paper No 7, June 30, 2003. 